\title{
Polymeric biomaterials with phosphorylcholine groups at the surface : on the photochemical surface modification of polyurethanes using aryl azides with a phosphorylcholine endgroup to improve hemocompatibility
}

Citation for published version (APA):

van der Heiden, A. P. (1998). Polymeric biomaterials with phosphorylcholine groups at the surface : on the photochemical surface modification of polyurethanes using aryl azides with a phosphorylcholine endgroup to improve hemocompatibility. [Doctoral Thesis, Maastricht University]. Universiteit Maastricht. https://doi.org/10.26481/dis.19980319ah

Document status and date:

Published: 01/01/1998

DOI:

10.26481/dis.19980319ah

Document Version:

Publisher's PDF, also known as Version of record

Please check the document version of this publication:

- A submitted manuscript is the version of the article upon submission and before peer-review. There can be important differences between the submitted version and the official published version of record. People interested in the research are advised to contact the author for the final version of the publication, or visit the DOI to the publisher's website.

- The final author version and the galley proof are versions of the publication after peer review.

- The final published version features the final layout of the paper including the volume, issue and page numbers.

Link to publication

\footnotetext{
General rights rights.

- You may freely distribute the URL identifying the publication in the public portal. please follow below link for the End User Agreement:

www.umlib.nl/taverne-license

Take down policy

If you believe that this document breaches copyright please contact us at:

repository@maastrichtuniversity.nl

providing details and we will investigate your claim.
}

Copyright and moral rights for the publications made accessible in the public portal are retained by the authors and/or other copyright owners and it is a condition of accessing publications that users recognise and abide by the legal requirements associated with these

- Users may download and print one copy of any publication from the public portal for the purpose of private study or research.

- You may not further distribute the material or use it for any profit-making activity or commercial gain

If the publication is distributed under the terms of Article $25 \mathrm{fa}$ of the Dutch Copyright Act, indicated by the "Taverne" license above,

Download date: 26 Apr. 2023 


\section{Polymeric Biomaterials with Phosphorylcholine Groups at the Surface}

On the photochemical surface modification of polyurethanes using aryl azides with a phosphorylcholine endgroup to improve hemocompatibility 
Heiden, Arthur P. van der

Polymeric biomaterials with phosphorylcholine groups at the surface: on the photochemical surface modification of polyurethanes using aryl azides with a phosphorylcholine endgroup to improve hemocompatibility.

Thesis Maastricht, 1998

ISBN 90-5681-028-6

Druk: Unigraphic, Maastricht

(C) A.P. van der Heiden, 1998 


\section{Polymeric Biomaterials with Phosphorylcholine Groups at the Surface}

On the photochemical surface modification of polyurethanes using aryl azides with a phosphorylcholine endgroup to improve hemocompatibility

\section{PROEFSCHRIFT}

ter verkrijging van de graad van doctor aan de Universiteit Maastricht, op gezag van de Rector Magnificus, Prof. Dr. A.C. Nieuwenhuijzen Kruseman, volgens het besluit van het College van Decanen, in het openbaar te verdedigen op donderdag 19 maart 1998 om 16.00 uur

$$
\text { door }
$$

Arthur Paul van der Heiden 
Promotor:

Prof. Dr. H.C. Hemker

Co-promotor:

Dr. Ir. L.H. Koole

Beoordelingscommissie: Prof. Dr. J. Rosing (voorzitter)

Prof. Dr. J. Feijen (Universiteit Twente)

Prof. Dr. W.Th. Hermens

Prof. Dr. H.A.J. Struijker Boudier

Prof. Dr. G.I. Tesser (Katholieke Universiteit Nijmegen)

Het verschijnen van dit proefschrift werd mede mogelijk gemaakt door steun van DSM Research (Geleen) en de Nederlandse Vereniging voor Biomaterialen. 
voor mijn ouders 


\section{List of abbreviations}

$\begin{array}{ll}\text { ADP } & \text { adenosine diphosphate } \\ \text { Alb } & \text { albumin } \\ \text { AT III } & \text { antithrombin III } \\ \text { BMA } & \text { n-butylmethacrylate } \\ \text { dansyl } & \text { dimethylaminonaphthalenesulfonyl } \\ \text { DMAP } & \text { dimethylaminopyridine } \\ \text { DMSO } & \text { dimethylsulfoxide } \\ \text { DOPC } & \text { dioleoyl phosphatidylcholine } \\ \text { DPPC } & \text { dipalmitoyl phosphatidylcholine } \\ \text { DPPS } & \text { dipalmitoyl phosphatidylserine } \\ \text { ESCA } & \text { electron spectroscopy for chemical analysis } \\ \text { Fg } & \text { fibrinogen } \\ \text { Fn } & \text { fibronectin } \\ \text { HEPES } & \text { 4-(2-hydroxyethyl)-1-piperazineethanesulfonic acid } \\ \text { HMWK } & \text { high molecular weight kininogen } \\ \text { IgG } & \text { immunoglobulin G } \\ \text { MPC } & \text { 2-methacryloyloxyethyl phosphorylcholine } \\ \text { NMR } & \text { nuclear magnetic resonance } \\ \text { PBS } & \text { phosphate-buffered saline } \\ \text { PC } & \text { phosphorylcholine (but phosphatidylcholine in Ch. 1) } \\ \text { PEG } & \text { poly(ethylene glycol), identical with poly(ethylene oxide) (PEO) } \\ \text { PEU } & \text { poly(ether urethane) } \\ \text { PK } & \text { prekallikrein } \\ \text { PRP } & \text { platelet-rich plasma } \\ \text { PS } & \text { phosphatidylserine } \\ \text { PTFE } & \text { polytetrafluoroethylene } \\ \text { PTMO } & \text { scanning electron microscopy } \\ \text { SEM } & \text { thin layer chromatography } \\ \text { THF } & \text { triphenylmethyl } \\ \text { TLC } & \\ \text { trityl } & \end{array}$




\section{Contents}

List of abbreviations

1. General Introduction 9

1.1 Biomaterials 9

1.2 Hemostasis 14

1.3 Hemocompatibility of artificial surfaces 20

1.4 Outline of this thesis 30

2. Synthesis of a Homologous Series of Bifunctional Photo- 37 reactive Compounds Carrying a Phosphorylcholine Moiety for the Surface Modification of Polymeric Biomaterials

3. Photochemical Coupling of Aryl Azides to Poly(ether urethane) Surfaces: Studies with a Fluorescent Model Compound

4. A Photochemical Method for the Surface Modification of Poly(ether urethanes) with Phosphoryicholine-containing Compounds to Improve Hemocompatibility

5. Adsorption of Proteins onto Poly(ether urethane) with a 89 Phosphorylcholine Moiety and Influence of Pre-adsorbed Phospholipid

6. General Discussion

Summary / Samenvatting

List of publications

Curriculum vitae 


\section{General Introduction}

\subsection{Biomaterials}

Numerous materials are used for medical devices that are interfaced with living systems. These biomedical materials or biomaterials include polymers (synthetic and natural), metals, and ceramics (Table 1). Applications range from medical implants such as orthopedic and cardiovascular devices to medical devices for extracorporeal use such as contact lenses and blood bags (Table 2).

Polymers are found in a wide array of medical devices since they are easy to process into different sizes and shapes (sheets, tubing, fibers) and can combine flexibility with strength. Furthermore, polymers can be designed with special properties such as porosity (e.g. in contact lenses and dialysis membranes), smoothness (e.g. in Teflon catheters), and biodegradability (e.g. in screws made from poly(lactic acid)). Metals are especially used in orthopedic and dental devices, where high strength and stiffness are essential. Ceramics are very strong, stiff, and hard (but brittle) materials that are often used as a coating material on orthopedic and dental devices to reduce wear.

Most of the materials listed in Table 1 were originally designed for their physical properties such as mechanical strength, durability and flexibility. Later, these materials were tested in a clinical environment where biocompatibility is a major issue. In recent years new materials have been developed that specifically address the problem of biocompatibility. ${ }^{1-3}$ Examples are poly(lactic acid) which was developed for biodegradable medical devices (screws, plates), Biomer (a polyurethane urea) which is commercially used in blood-contacting devices (catheters, heart-assist pumps), various polyurethanes (Pellethane ${ }^{0}$, Avcothane $\left.{ }^{1}\right)^{1}$ which are also used in blood-contacting devices, and various types of polyacrylates which have found wide application in contact lenses and bone cements. Criteria for the development of biomaterials inciude: 


\section{Physicochemical properties}

- chemical inertness

- mínimal wear

- free from leachable additives (such as plasticizers in polymers)

- distinct mechanical properties (toughness, strength, smoothness)

- other desirable properties (composition, permeability, equilibrium swelling)

\section{Biological interactions}

- non-toxic

- non-carcinogenic

- non-inflammatory

- sterillizable

- non-thrombogenic (if in contact with blood)

- non-biodegradable (unlless specifically desired)

Table 1. Applications of biomaterials *

\begin{tabular}{ll}
\hline \multicolumn{1}{c}{ Material } & \multicolumn{1}{c}{ Applications } \\
\hline $\begin{array}{l}\text { Polymers } \\
\text { Polyethylene }\end{array}$ & Orthopedic devices, tendon/ligament, catheters \\
Poly(vinyl chloride) & Tubing, catheters \\
Dacron ${ }^{\circledR}$ & Vascular grafts, tendon/ligament \\
Teflon ${ }^{\circledR}$ b & Vascular grafts, catheters \\
Sillicone rubber & Tubing, catheters, breast implants \\
Polyurethanes & Tubing, catheters, pacemaker leads, blood bags \\
Poly(methyl methacrylate) & Ophthalmologic devices, bone cement \\
Hydrogels c & Ophthalmologic devices, drug delivery devices \\
Poly(lactic acid) & Orthopedic devices (absorbable) \\
Cellulose & Dialysis membranes \\
Collagen (reprocessed) & Ophthalmologic devices, absorbable sutures and \\
& wound dressings \\
Metals & \\
Stainless steel & Orthopedic devices, sutures \\
Titanium alloys & Orthopedic and dental devices, pacemakers \\
Cobalt chromium alloys & Heart valves, orthopedic and dental devices \\
Ceramics & \\
Alumina & Orthopedic and dental devices \\
Hydroxyapatite & Orthopedic and dental devices \\
Carbon & Heart valves \\
\hline
\end{tabular}

"Adapted from Ratner" and Silver ${ }^{3}$

${ }^{a}$ Knitted or woven poly(ethylene terephthalate)

'Polytetrafluoroethylene (often porous, as in expanded Teflon ${ }^{(8)}$ or Gore-Tex (8)

"Examples are poly (2-hydraxyethyl methacrylate) and poly(vinyl alcohol) 
Table 2. Use of biomedical devices *

\begin{tabular}{lc}
\hline \multicolumn{1}{c}{ Application } & Numbers used per year ${ }^{\mathrm{a}}$ \\
\hline Ophthalmologic & \\
Contact lenses & $250,000,000 \mathrm{~b}$ \\
Intraocular lenses & $1,400,000$ \\
Retinal surgery implants & 50,000 \\
Cardiovascular & \\
Vascular grafts & 350,000 \\
Arteriovenous shunts & 150,000 \\
Pacemakers & 130,000 \\
Hieart valves & 75,000 \\
Orthopedic & \\
Hips & 90,000 \\
Knees & 65,000 \\
Shoulders, finger joints & 50,000 \\
Other devices & \\
Catheters & \\
Blood bags & $200,000,000$ \\
Sutures & $30,000,000$ \\
Renal dialyzers & $20,000,000$ \\
Wound drains & $16,000,000$ \\
Oxygenators & $3,000,000$ \\
Breast prostheses & 500,000 \\
Dental implants & 100,000 \\
\hline * Adapted from Ratner & 20,000 \\
Approximate annual usage in United States & \\
' & \\
Worldwide & \\
\hline
\end{tabular}

Since the research described in this thesis was focused on the design of new polymeric biomaterials with improved hemocompatibility the remainder of this chapter will deal with some aspects of the interaction between blood and foreign (polymeric) materials.

Medical devices that are used in contact with blood always influence blood components such as erythrocytes, leukocytes, platelets, and plasma proteins. Especially the interaction of cardiovascular implants with blood components can cause serious problems since these devices are intended to remain in the body for an 
extendled period. The implants are recognized by the body as foreign and this results in a process of thrombosis, often followed by the formation of thromboemboli. In general, this process starts with adsorption of plasma proteins followed by platelet adsorption. Adsorbed platelets will become activated and trigger blood coagulation (see section 1.2). Therefore, patients with cardiovascular implants will need lifelong administration of anticoagulants (e.g. heparin, coumarins) and/or antiplatelet drugs (e.g. aspirin, dipyridamole, sulfinpyrazone). Since these drugs can cause bleeding disorders it is important that materials are developed that require a minimal drug dosage.

In the field of artificial blood vessels a material has yet to be found that can be used if the diameter is less than about $5 \mathrm{~mm}$. Larger artificial grafts have been successfully applied to replace damaged portions of the aorta, carotid arteries, and femoral arteries. ${ }^{3,5,6}$ These wide-bore grafts are made from materials like Dacron (grafts $>10 \mathrm{~mm}$ ) or Teflon (grafts between 6 and $10 \mathrm{~mm}$ ), which are often preclotted with blood before implantation., ${ }^{3,5}$ For the replacement of coronary arteries the patient's own saphenous vein is normally used since replacement with small-bore $(<5 \mathrm{~mm}$ ) artificial grafts often causes obstruction by clotting. Since this vein is often unavailable because of prior surgery or inadequate because of its small diameter or inferior condition, an urgent need exists for small-diameter grafts with improved hemocompatibility.

New materials for the construction of (small-bore) artificial vascular grafts should meet several requirements:

- increased hemocompatibility (minimal interaction with blood components)

- matching compliance to natural vessels

- sufficient strength and flexibility combined with small diameter and thin wall

- biostability (e.g. no surface cracking)

- general requirements for biomaterials (see above)

Polyurethanes are a class of materials with promising properties in this respect. ${ }^{1}$ Therefore, this class of polymers was selected as a base material in this study which is aimed at optimizing surface properties of polymers in relation to hemocompatibility. A medical-grade poly(ether urethane) from Dow Chemical was used: Pellethane 2363-55D (Fig. 1). 

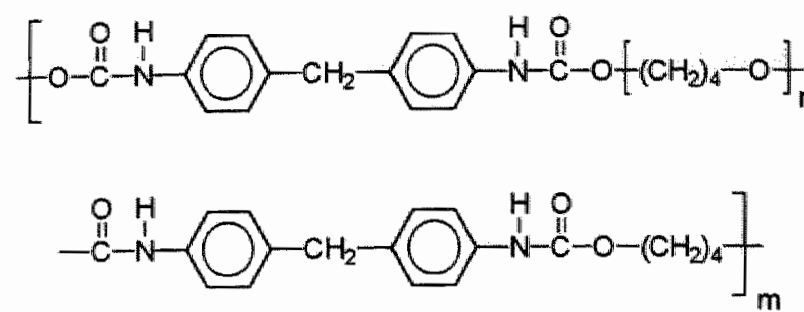

Figure 1. Structural formula of Pellethane 2363-55D. It is made of methylene-4,4'-diphenyldiisocyanate, polytetramethylene oxide, and 1,4butanediol.

From empirical observations it was found that the structural properties of Pellethane and other polyurethane elastomers can be characterized as follows:

- the hard and rigid urethane segments separate into glassy or semicrystalline domains

- the soft and flexible polyether segments form an amorphous or semicrystalline matrix in which the hard domains are dispersed

- the hard domains act as multifunctional cross linking sites and as reinforcing fillers which results in stiff and flexible materials

- the driving force for the segregation into domains is provided by the chemical incompatibility of the hard and soft segments

By varying the types and amounts of hard and soft segments in the polymer chain a whole range of pollyurethanes can be prepared from hard and brittle to soft and tough materials.' Several polyurethane elastomers have been developed with excellent mechanical properties. These materials can be used to produce strong, small, and thin-walled vascular grafts with a high resistance to flex-fatigue. To correct the compliance mismatch with natural vessels porous polyurethanes have been developed such as ChronoFlex ${ }^{6}$ Polyurethane elastomers tend to be more blood compatible than most other polymers. By varying the composition as described above polyurethanes have been developed with moderate hemocompatibility, ${ }^{1}$ although application of polyurethanes in small-bore vascular grafts has not been successful. ${ }^{6}$ The goal of this study was to find ways of modifying the surface of these polyurethanes to optimize their hemocompatibility. 


\subsection{Hemostasis}

In order to understand the factors influencing the hemocompatibility of artificial vascular grafts it is essential to have knowledge about the hemostatic processes that occur in natural vessels. Hemostasis is the process by which the body suppresses bleeding and maintains blood in the fluid state within the vessel. It involves several mechanisms, including:

- vascular constriction

- platelet plug formation

- blood coagulation or clotting (fibrin forming system)

- fibrinolytic system (dissolving of fibrin by plasmin)

If a blood clot develops in an undamaged vessel (e.g. due to atherosclerosis) the process is called thrombosis, which can be life-threatening when blood flow to an important organ is suddenly obstructed (infarction) or when the clot is suddenly released causing obstruction elsewhere (thromboembolism).

Healthy blood vessels are equipped with a continuous lining of smooth endothelial cells that facilitate blood flow and participate in hemostatic processes. The luminal surface of the endothelium is coated with glycocalyx, a mucopolysaccharide (glycosaminoglycan), of which heparan sulfate is the main component. ${ }^{7}$ Heparan sulfate weakly stimulates the anti-coagulant antithrombin III, a potent inhibitor of thrombin and factor Xa (see section on blood coagulation). Another important component of the endothelium is thrombomodulin which can bind thrombin, thereby inactivating it. ${ }^{8}$ Furthermore, the thrombomodulin-thrombin complex activates protein $C$ which then acts as an anti-coagulant my inactivating the important cofactors V and VIII. Platelet aggregation on the vessel wall is prevented by ADPase, which degrades ADP (adenosine diphosphate), an activator of platelet aggregation, and by prostacyclin (a prostaglandin), a platelet inhibitor. ${ }^{7}$

On vascular injury the endothelium is disrupted and subendothelial collagen and tissue factor (tissue thromboplastin) are exposed. Platelets quickly adhere to the collagen fibers, initiating platelet plug formation (see next section). The exposed tissue factor initiates the process of blood coagulation (see section on coagulation), resulting in the formation of a fibrin mesh. This mesh reinforces the initial platelet plug and also entraps erythrocytes and leucocytes, thus providing a fully formed blood clot. 


\section{Platelet plug formation}

When a vessel wall is damaged vascular constriction diminishes initial blood loss and reduces the area that must be occluded by a hemostatic plug. ${ }^{7}$ Then blood platelets adhere to damaged cell surfaces and exposed (sub-endothelial) collagen (via receptors). Platelet adhesion is dependent on Von Willebrand factor, which also functions as a carrier of factor VIII in plasma (VIII-vWF) ${ }^{9}$ Adherence of platelets initiates activation and stimulates release of $\mathrm{ADP}$ from adherent platelets or endothelial cells. ADP is a potent initiator of platelet aggregation resulting in the transformation of ambient discoid platelets into reactive spiny spheres (pseudopod formation can be observed at this stage) which form a mass of aggregated platelets. Platelet aggregation is further dependent on fibrinogen (which can bind to glycoprotein receptors on the platelet membrane) and $\mathrm{Ca}^{2+}$. Thromboxane $\mathrm{A} 2$ (a prostaglandin synthesized in the platelet's cytoplasm from phospholipids) is a potent platelet aggregating agent, a vasoconstriction agent, and a mediator of the next step: the platelet release reaction. Platelet release is a calcium-dependent reaction which eventually leads to a mass of degenerated platelets without membranes. During this process substances such as $\mathrm{Ca}^{2+}, \mathrm{ADP}$, factor $\mathrm{V}$, and serotonin (a vasoconstrictor) are released. Thrombin (traces from plasma or larger quantities generated in the coagulation process) has a strong stimulating effect on all steps (platelet adhesion, aggregation, and release).

During platelet aggregation another process takes place which is essential for blood coagulation (as described in the next section). Non-activated platelets have a membrane bilayer in which the phospholipids are asymmetrically distributed: the outer membrane leaflet mainly consists of the neutral choline-containing phospholipids phosphatidylcholine (PC) and sphingomyelin (and some phosphatidylethanolamine) while the negatively charged phosphatidylserine (PS) and phosphatidylinositol are almost exclusively found in the inner membrane leaflet. ${ }^{10,11}$ When platelets are activated by collagen and thrombin a flip-flop reaction (transbilayer movement of phospholipids) occurs in which the asymmetric distribution of phospholipids is lost. ${ }^{11,12}$ An important consequence is the net transport of negatively charged PS from the inner to the outer membrane leaflet. This results in the formation of a procoagulant surface. ${ }^{1-13}$ In a process called shedding smalll 
membrane vesicles (microvesicles) are released from the membrane of activated platelets which also have lost membrane asymmetry, thereby also providing a procoagulant surface on which the surface-dependent reactions of the coagulation cascade can occur. ${ }^{14}$

\section{Blood coagulation}

Blood coagulation involves a series of enzymatic reactions resulting in the formation of insoluble fibrin which reinforces the initially formed platelet plug. ${ }^{15}$ The process is dependent on the presence of activated platelets since they provide a catalytic (procoagulant) surface of phospholipids on which several of the coagulation reactions can occur. The series of reactions involved in blood coagulation is often called the "coagulation cascade" since at every reaction step an enzymatic amplification takes place, eventually resulting in the production of multiple fibrin molecules from few initiator molecules (tissue factor). The coagulation factors (except tissue factor) are present in plasma in their inactive form (zymogens). Limited proteolysis result in the formation of the active enzyme (often a serine protease) which can activate the next zymogen.

The classical coagulation cascade is divided in an intrinsic (left part of Fig. 2) and extrinsic (right part of Fig. 2) pathway. ${ }^{15}$ The intrinsic pathway (intrinsic since all coagulation factors involved are present in plasma) or contact activation pathway was found to start with the activation of factor XII (probably by a conformational change of the protein) on a negatively charged surface such as glass or kaolin in vitro, in the presence of high molecular weight kininogen (HMWK) and prekallikrein (PK) ${ }^{16}$ However, the mechanism of factor XII activation in vivo is not clear. Furthermore, since individuals with deficiencies in the contact activation factors (factor XII, HMWK, and PK) do not experience bleeding episodes, in contrast to patients with factor XI deficiencies, factor XII is no longer considered an important coagulation factor in vivo. ${ }^{16}$ Nevertheless, factor XII, HMWK, and PK probably play an important role in triggering the coagulation cascade when circulating blood comes in contact with an artificial surface in the body, such as an artificial heart valve or vascular graft (see section 1.3). 
Contact activation in vitro
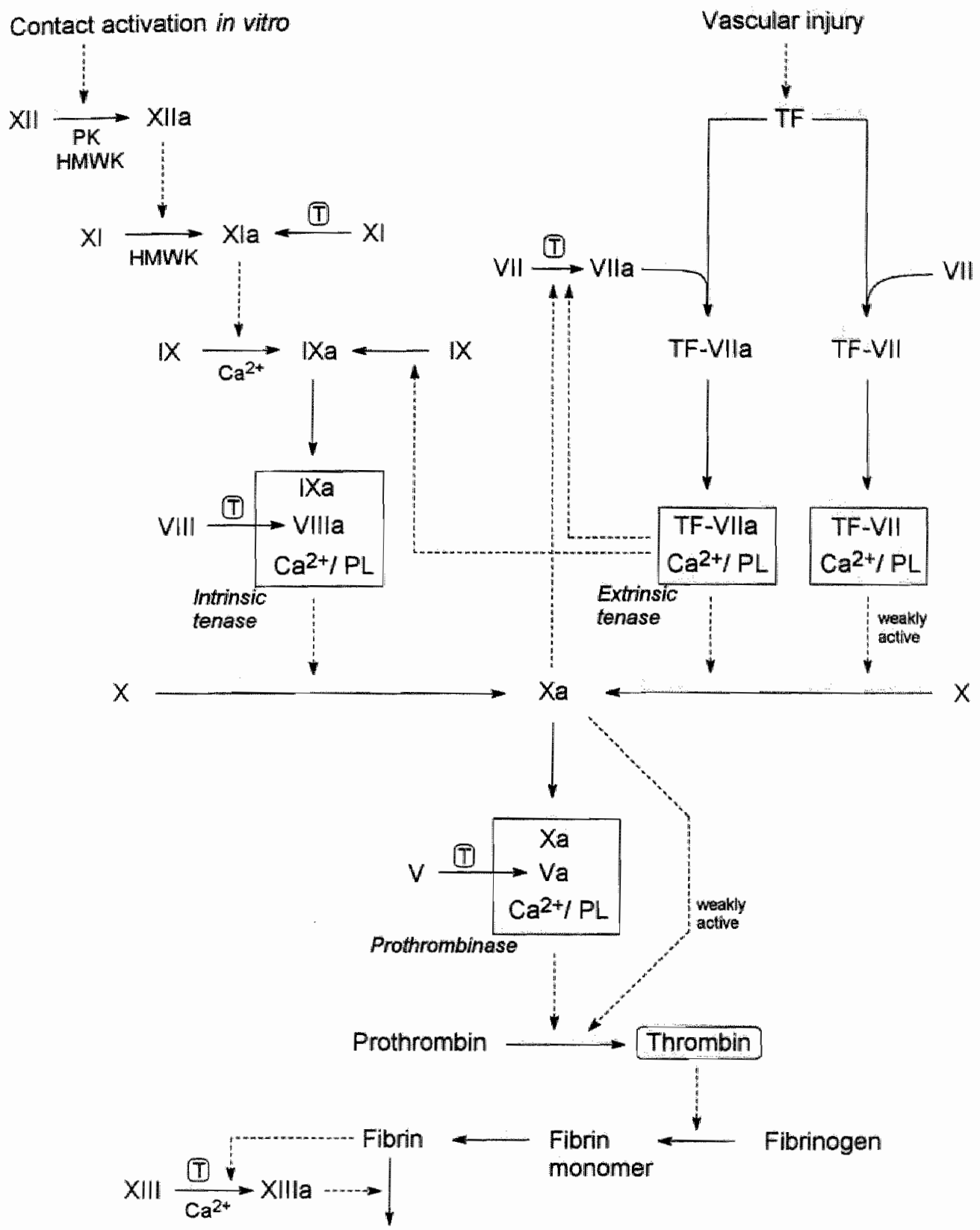

Fibrin net

Figure 2. Blood coagulation cascade. Solid arrows indicate conversion while dashed arrows indicate activation. Abbreviations: TF (tissue factor), T (thrombin), PL (procoagulant phospholipid surface), HMWK (high molecular weight kininogen), PK (prekallikrein), a (in combination with a roman numeral: activated clotting factor). 
The extrinsic pathway (extrinsic since one factor - tissue factor - is only present outside the plasma) starts with the exposure of tissue factor from the subendothelium after vascular injury ${ }^{17}$ Recent research has shown that the intrinsic pathway is in fact part of the extrinsic pathway (see below). Tissue factor forms a complex with factor VII which circulates in plasma. This complex, in the presence of $\mathrm{Ca}^{2+}$, slowly converts some factor $\mathrm{X}$ into the serine protease $\mathrm{Xa}$. Factor $\mathrm{Xa}$ proteolytically converts factor VII into VIIa which, once combined with tissue factor (TF-VIIa), is much more efficient in producing Xa than TF-VII (a positive feedback reaction). Furthermore, this "extrinsic tenase" complex accelerates the activation of factor VII in another positive feedback reaction. The complex also provides a link between the extrinsic and intrinsic pathways by activating factor IX, in a process known as the Josso loop (see below). Since tissue factor apoprotein is tightly associated with phospholipids it is not dependent on activated platelets as a source of anionic phospholipids although PS can enhance its activity. ${ }^{18}$

Factor Xa forms a one-to-one complex ("prothrombinase") with the cofactor Va on an anionic phospholipid surface (from activated platelets), in the presence of $\mathrm{Ca}^{2+}$. The prothrombinase complex converts prothrombin into thrombin (a serine protease) which accelerates its own formation by activating factor $\mathrm{V}$. Thrombin also accelerates its own production by activating several other coagullation factors: factor VII, VIII, and XI. Thrombin proteolytically converts fibrinogen to fibrin monomer, which spontaneously polymerizes into linear fibrin molecules. Thrombin also activates factor XIII in the presence of $\mathrm{Ca}^{2+}$ in a process accelerated by fibrin. Factor XIIIa forms cross-links between fibrin molecules, resulting in the formation of a strong fibrin mesh.

As stated above, the intrinsic part of the coagulation cascade is linked with the extrinsic part through the activation of factor IX by the extrinsic tenase complex (the Josso loop). This positive feedback reaction for the formation of factor Xa becomes especially important when the available amount of tissue factor runs out. Factor IXa assembles on an anionic phospholipid surface (from activated platelets) in a complex ("intrinsic tenase") with cofactor VIIIa, in the presence of $\mathrm{Ca}^{2+}$. This complex is more efficient in producing factor $\mathrm{Xa}$ than the extrinsic tenase complex. The importance of the intrinsic pathway is stressed by the fact that people with deficiencies in factor VIII or IX (causing hemophilia A and B respectively) have 
severe bleeding disorders. The recent discovery of the activation of factor XI by thrombin (enhanced in the presence of a negatively charged surface as provided by heparin or dextran sulfate) could also explain why patients deficient in factor XI show (mild) bleeding disorders. ${ }^{19}$ The activation of factor $\mathrm{IX}$ by XIa (in the presence of $\mathrm{Ca}^{2+}$ ) increases production of Xa via the intrinsic pathway. In conclusion, the extrinsic pathway is essential in initiating blood coagulation while the intrinsic pathway is essential in maintaining and amplifying the process.

\section{Regulation of hemostatic processes}

In the first part of this chapter the important role of the endothelium was already discussed in controlling platelet plug formation and blood coagulation. Blood coagulation is confined to the damaged vessel area since platelets only aggregate at that site, providing a procoagulant phospholipid surface. Also entrapment of thrombin in the fibrin mesh and dilution of the coagulation factors by the blood flow restrict clot formation to the site of injury. Several protease inhibitors are known that control coagulation, a few of which will be mentioned here.

Antithrombin III (AT III) is particularly important in controlling blood coagulation since it can (slowly) deactivate thrombin by irreversibly binding it in a one-to-one complex (acting as a substrate). ${ }^{15}$ In addition, AT III inhibits factors IXa, $\mathrm{Xa}$, and XIa. The anti-coagulant activity of AT III is strongly enhanced by heparin, a sulfated glycosaminoglycan present in plasma in minute amounts. Heparin (from animal tissues) is widely used as an anti-coagulant in the clinic. The inhibitor $\alpha_{2}$ macroglobulin binds to several coagulation factors, thereby inactivating them, but without destroying them (destroying is done in various ways). The extrinsic pathway inhibitor (EPI, also called tissue factor pathway inhibitor, TFPI) binds to the ternary complex VIIa-TF-Xa only. ${ }^{15}$ This complex inhibits VIIa-TF in converting factor $\mathrm{X}$ to Xa. However, it does not inhibit VIIa-TF in converting factor IX to IXa. Hence, coagulation can continue via the intrinsic pathway. 


\subsection{Hemocompatibility of artificial surfaces}

\section{Thrombogenesis on artificial surfaces}

A major problem encountered after the implantation of cardiovascular devices such as heart valves and vascular grafts is thrombus formation (thrombogenesis) on the artificial surface. People with cardiovascular implants need life-long medication to avoid thrombosis as was mentioned in section 1.1 . The problem also exists when blood is temporarily outside the body as in dialysis and heart-lung machines. But in this case the blood can be temporarily heparinized to avoid clotting. Before the blood is returned to the patient the antagonist protamine sulfate is added to neutralize the anti-coagulant action of heparin. Still, blood platelets can be damaged by the procedure and thrombocytopenia can occur.

When blood contacts an artificial surface a number of events occur. The first event is the immediate deposition of a film of plasma proteins (see below) ${ }^{20-23} \mathrm{Next}$, blood platelets start to adhere to the protein covered surface (enhanced by the presence of fibrinogen) while simultaneously the intrinsic coagulation is triggered by the adsorbed contact activation factors as outlined in Figure 3. ${ }^{16,24}$ The activated platelets will release several factors that enhance platelet aggregation (such as ADP) and blood coagulation (such as factor $\mathrm{V}$ ), as was discussed in section 1.2. Furthermore, activated platelets provide a procoagulant phospholipid surface on which the surface-dependent reactions of the coagulation cascade can occur. This results in the formation of a thrombus on the surface consisting of aggregated platelets as well as erythrocytes and leucocytes entrapped in a fibrin network.

It is now generally believed that the composition and organization of the initially formed protein film has a profound influence on the subsequent platelet interactions and contact activation, thus also determining the blood compatibility of the surface. ${ }^{20-23}$ The composition of the protein layer depends on the type of surface and rapidly changes in time. It has become clear that proteins can displace each other on the surface and it was proposed that this displacement occurs in an ordered sequence, known as the "Vroman effect". ${ }^{21}$ On a hydrophilic glass surface the sequence of adsorption (in vitro) was found to be (Alb adsorbs first): $:^{25,26}$ 


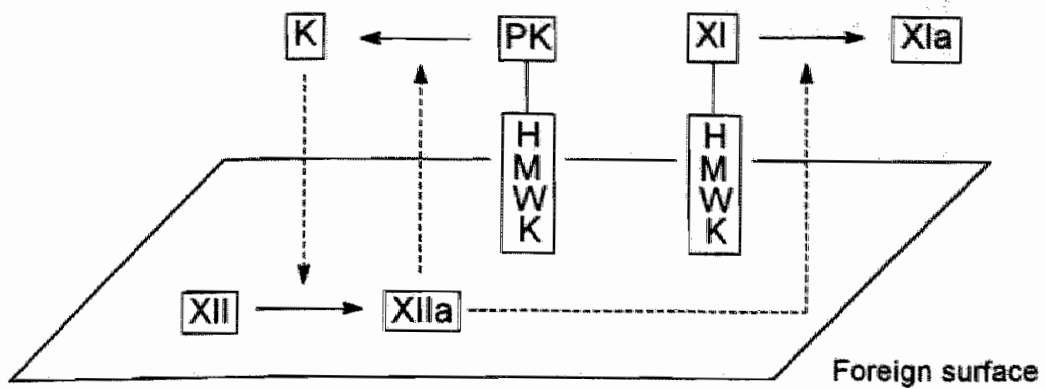

Figure 3. Contact activation on a foreign surface. HMWK is present in plasma in $1: 1$ complexes with PK and factor XI. HMWK and factor XII adhere to foreign surfaces, especially negatively charged hydrophilic surfaces such as glass and kaolin. Hydrophobic polymer surfaces also have an affinity for these proteins which often replace the initially adsorbed Fg (Vroman effect, see text). The activation of XII on the surface (probably via a conformational change) is enhanced by kallikrein (K). Factor XIIa activates the conversion of $\mathrm{PK}$ to $\mathrm{K}$ and also activates $\mathrm{XI}$ which will (via the intrinsic coagulation pathway) eventually lead to fibrin formation. Solid arrows indicate conversion while dashed arrows indicate activation. Abbreviations: see Fig. 2.

This sequence of adsorption nearly corresponds with the sequence of decreasing concentration of the proteins in plasma (Table 3).

Table 3. Physical data and plasma concentrations of the principal proteins involved in the "Vroman effect" "

\begin{tabular}{lllllll}
\hline & Alb & IgG & Fg & Fn & XII & HMWK \\
\hline $\mathrm{C}(\mu \mathrm{M})$ & 600 & 100 & 7.3 & 0.67 & 0.38 & 0.64 \\
$\mathrm{MW}(\mathrm{kg} / \mathrm{mol})$ & 66 & 150 & 330 & 450 & 80 & 110 \\
$\mathrm{D}\left(10^{-7} \mathrm{~cm}^{2} / \mathrm{s}\right)$ & 6.1 & 4.0 & 2 & - & - & - \\
$\mathrm{C} \cdot \mathrm{D}^{1 / 2}$ & 1500 & 200 & 10 & - & - & - \\
\hline
\end{tabular}

"Abbreviations: Alb (albumin), IgG (immunoglobulin G), Fg (fibrinogen), Fn (fibronectin), HMWK (high molecular weight kininogen). 
To explain these observations one should look at the initial stage of the process (in which desorption plays no role yet) which is diffusion controlled adsorption: ${ }^{20,21,27}$

$$
\frac{d \Gamma}{d t}=C_{0}\left(\frac{D}{\pi t}\right)^{1 / 2} \quad \text { or, after integration: } \quad \Gamma=2 C_{6}\left(\frac{D t}{\pi}\right)^{1 / 2}
$$

where $\Gamma$ is the surface concentration $\left(\mathrm{mg} / \mathrm{cm}^{2}\right)$ of a protein at time $t(\mathrm{~s}), D$ the diffusion coefficient $\left(\mathrm{cm}^{2} / \mathrm{s}\right)$ and $\mathrm{C}_{0}$ the bulk concentration of the protein $\left(\mathrm{mg} / \mathrm{cm}^{3}\right)$.

From these data it is clear that albumin is the predominant protein diffusing to the surface at the initial stage. Albumin will be the predominant adsorbed protein at this stage if there is sufficient interaction between the protein and the surface to lead to a reasonable residence time. The proteins present in lower concentrations (or better: the proteins with lower diffusion rates) can displace the already adsorbed proteins partly or completely, depending on their binding affinity to the surface. ${ }^{.} \mathrm{A}$ kinetic model has been developed to explain competitive protein adsorption at surfaces. ${ }^{28}$ In the protein adsorption sequence on glass the proteins with the lowest plasma concentrations have (by chance) the highest binding affinity to the surface. Hence, on glass HMWK and factor XII will eventually (within a few minutes) cover the surface and initiate the intrinsic coagulation pathway. It should be noted however that the displacement of proteins is normally incomplete as is illustrated by the fact that a residual amount of $\mathrm{Fg}$ could be found on glass $\left(0.01-0.02 \mu \mathrm{g} / \mathrm{cm}^{2}\right)$.

On polymeric materials, which are mostly hydrophobic, the protein displacement reactions are slower than on glass and the composition of the resulting protein layer can be quite different. ${ }^{21}$ Furthermore, desorption of a protein from a hydrophobic surface usually does not occur whereas proteins can often be removed from a hydrophilic surface by exposure to extreme $\mathrm{pH}$, high ionic strength, or by extensive rinsing. ${ }^{29}$ In other words, proteins have a higher affinity for hydrophobic surfaces than for hydrophilic surfaces. An illustrative example is the adsorption of plasma proteins to a polyethylene surface (in vitro). ${ }^{21}$ It was found that $\mathrm{Fg}$ is less readily displaced from the polyethylene surface than from a hydrophilic glass

Proteins hardly desorb spontaneously from a surface since they are usually attached through multiple binding sites. The probability of a number of binding sites being released at the same time is quite small. But if the space of a (temporarily) released binding site is immediately occupied by another protein exchange can occur. 
surface. HMWK and factor XII were found to be major Fg displacing proteins on polyethylene (as well as on glass). Alb and IgG on the other hand showed rapid adsorption to a steady-state value, thus not showing a Vroman effect. These observations seem to be true for other hydrophobic polymers as well. ${ }^{30}$ Hence, all of these proteins (and others) can be present in the resulting protein film.

The presence of $\mathrm{Fg}$ on the surface is particularly important since this protein is essential for platelet aggregation. It was shown that adsorbed $\mathrm{Fg}$ is highly platelet. reactive and it was suggested that it could be an important participant in platelet adhesion to a foreign surface as well. ${ }^{31}$ For this reason the preferential adsorption of Fg on a biomaterial is normally considered as "bad" whereas preferential adsorption of Alb (to the exclusion of other proteins) is often considered as "good" since this protein is inert towards platelets. ${ }^{23}$

An important factor in the interaction between the protein film and platelets is also the degree of denaturation of the adsorbed proteins. ${ }^{32}$ Especially on hydrophobic surfaces proteins are likely to denature gradually since hydrophobic interactions with the surface require conformational changes of the protein to expose its internalized hydrophobic domains. The altered conformation of an adsorbed protein can result in a very different reaction to blood cells. It has been suggested that part of the adsorbed $\mathrm{Fg}$ on polymeric surfaces changes its conformation to a form unrecognizable to $\mathrm{Fg}$ receptors on platelets. ${ }^{32}$

Flow conditions influence all thrombotic processes to a major extent. A high shear rate of the blood flow (as in the arteries) leads to a "white" platelet thrombus since clotting factors such as thrombin are rapidly diluted by the plasma whereas a low shear rate of the blood flow (as in the veins) leads to a "red" thrombus composed of platelets, fibrin, and entrapped red blood cells. If areas exist on a biomedical device where blood flow is disturbed, hampered, or even absent thrombi will quickly develop. High shear rates can be destructive to blood cells and initiate platelet activation.

\section{Surface modification of polymeric materials}

While the mechanical properties of a medical device are determined by the bulk of the material the hemocompatibility is determined by its surface. Blood interactions are mediated by the adsorbed proteins at the surface. It seems that the response of 
blood platelets to the protein film determines the hemocompatibility of a material to a large extent. ${ }^{22,23}$ Although it is very difficult to explain why certain polymers are more hemocompatible than others three major points are generally recognized that determine the thrombogenicity of a biomaterial:

- surface chemistry (composition)

- surface charge

- surface morphology (roughness, texture)

The surface composition of a polymeric material always differs from the bulk composition since molecular groups at the surface are not surrounded by similar groups but interact with completely different molecules such as oxygen or water. The material surface rearranges to minimize its thermodynamic free energy and this can result in a surface that is enriched in certain polymeric groups. Furthermore, the surface will rapidly become covered by compounds from the environment (water, hydrocarbons) while surface groups can also react with reactive compounds such as oxygen. Hydrophobic polymer surfaces (Teflon, polyethylene) have a high affinity to plasma proteins (including fibrinogen) which will eventually result in thrombogenesis. Some hydrophilic polymer surfaces (in particular poly(ethylene oxide)) have a very low affinity to proteins and are relatively non-thrombogenic (see below).

The surface charge of the material (and its distribution across the surface), which is determined by the chemical groups at the surface, is important since adsorbing proteins also have charged chemical groups that can be repelled by or attracted to charged surface groups. A small negative charge at the surface generally leads to lower thrombogenicity (perhaps since many plasma proteins, including fibrinogen, have a net negative charge at physiological acidity, $\mathrm{pH} 7.4$ ). ${ }^{23}$ But the charge distribution on the polymer surface and the protein is often unpredictable or unknown and it is this distribution that determines the degree of interaction.

Surface morphology also plays a role in the thrombogenic reaction of a material but not as much as previously thought. It is now generally believed that surfaces that do not contain large irregularities (of more than about $1 \mu \mathrm{m}$ ) are appropriate for blood-contacting applications if care is taken to wet the surface before use (in order to fill cavities or grooves with water, thus expelling air bubbles which are known to denature proteins). ${ }^{22}$ Areas where flow is seriously hampered should be avoided 
since thrombi will develop there. Very smooth surfaces such as Teflon could have the advantage over other materials that at high shear rates (arterial flow) thromboemboli may be released before they grow too large to be dangerous. ${ }^{23} \mathrm{On}$ the other hand, certain rough surfaces may stimulate thrombus formation without blocking the device and hold it tightly bound to the surface resulting in a "passivated" surface. ${ }^{23}$

It was suggested that a hemocompatible surface should have a low affinity towards proteins and should therefore probably be amorphous, hydrophilic, solvated by water, non-electrolytic, and hydrogen-bond accepting, although many exceptions exist. ${ }^{33}$ Metals and ceramics would then be unsuited for blood-contacting applications since they are crystalline and unsolvated by water. Glass would be unsuited since it is unsolvated by water and acts as a $\mathrm{H}$-bond donor (its $\mathrm{Si}-\mathrm{OH}$ groups interact strongly with proteins). Polymers such as polyethylene and Teflon would be unsuited because they are very hydrophobic while a polymer such as poly(vinyl alcohol) would be unsuited because it is a H-bond donor. Polymers that are well-suited include polyacrylamide, agarose (in spite of the fact that it is a H-bond donor as well as a H-bond acceptor) and polyethers such as poly(tetramethylene oxide) (PTMO) and poly(ethylene oxide) (PEO). Especially PEO is important since it is the least protein adsorptive of all known polymers. ${ }^{33,34}$

Surface modification of polymers in order to improve blood-contacting properties has become a popular method of developing new biomaterials. ${ }^{35-37}$ This method is often more efficient than the development of a new polymer since it is in general very difficult to create a polymer that combines excellent mechanical properties with adequate blood compatibility.

Physical and chemical methods can be distinguished for the modification of polymeric surfaces. Physical modification methods include the adsorption of compounds such as albumin, heparin, and phospholipids to the surface. Polymers can be physically attached to the surface of other polymers through adsorption (followed by cross-linking to stabilize them) or via the formation of interpenetrating networks. Endothelial cells can be seeded onto a polymer surface to grow into a smooth layer of cells. Chemical methods include the plasma treatment of polymers to induce surface oxidation or to incorporate small chemical groups such as hydroxyl and amino groups. Several strategies exist to covalently couple alkyl groups, PEO, albumin, heparin, phospholipids (and phosphorylcholine-containing compounds), 
prostaglandins, dipyridamole, and other compounds to a polymer surface, depending on the type of surface ${ }^{35-37}$ Some of the more important surface modification methods will be explained here in some detail.

Poly(ethylene glycol) (PEG, synonymous with PEO) is widely used as a coating on other polymers to improve hemocompatibility. ${ }^{35-37}$ PEG can be made with varying molecular weights and can swell to any degree in water depending on the number of cross-links in the polymer (freely soluble in water when not cross-linked). This hydrogel has a very low affinity towards plasma proteins ${ }^{34}$ and blood platelets ${ }^{38}$ which is often attributed to the combination of high hydration and steric repulsion of proteins by the highly mobile polymer chains. ${ }^{37}$ Since PEG has low dimensional stability it is normally grafted to the surface of polymers that do have good mechanical properties. ${ }^{39}$ It has also been incorporated into the surface of polyurethanes and other polymers via interpenetrating networks. ${ }^{40} \mathrm{PEG}$ can also be incorporated in polymers as part of the polymer chain which is often done to prepare hydrophilic polyurethanes with improved hemocompatibility. ${ }^{1,41}$ Another polyether, poly(tetramethylene oxide) (PTMO), is also often used in polyurethanes (see Fig. 1). In contrast to PEG it hardly swells in water but it also has a low affinity to proteins and platelets. ${ }^{33}$

Alkylation of hydroxyl or amino groups at the polymer surface can be used to reduce protein adsorption (since less $\mathrm{H}$-bonds are possible) and to make the surface more hydrophobic. Albumin, which is a highly hydrophobic protein (on the hydrophobic chromatography scale), ${ }^{42}$ preferentially adsorbs to alkylated polyurethane surfaces and does not easily desorb from this surface. ${ }^{43}$ Adsorbed albumin can diminish subsequent fibrinogen adsorption and decrease thrombogenesis. ${ }^{44}$ It was found that $\mathrm{C}_{18}$-alkylated polyurethane surfaces have enhanced hemocompatibility due to enhanced albumin adsorption..$^{45}$ For long-term implants the usefulness of physically adsorbed albumin is questionable since it can be replaced by other plasma proteins. Covalently coupled albumin ${ }^{46}$ could stay on the surface longer but can eventually be degraded by enzymes.

Heparin is one of the most frequently used anti-coagulants to improve the hemocompatibility of artificial surfaces ${ }^{35,37}$ It has been bound both physically and chemically to surfaces. Chemical coupling methods can be further divided in methods in which heparin is coupled ionically or covalently. Only the latter method guarantees that heparin is not released from the surface. If heparin is slowly released 
from the surface it acts as an anti-coagulant by accelerating the action of antithrombin III on thrombin and several other proteases in plasma (section 1.2). The surface will be slowly depleted of heparin as a result of which this method can only be applied in temporarily implanted devices (or in extracorporeal devices). It was found that covalently bound heparin can also enhance the activity of AT III, especially if a spacer molecule is present between the surface and the heparin molecule. ${ }^{47-49}$ PEG of various chain lengths has been used as the spacer in order to combine the low protein/platelet adhesion often found on PEG-covered surfaces with the anti-coagulant properties of heparin. ${ }^{49}$ In a procedure to modify a polyurethane surface the terminal hydroxyl groups of PEG were first converted into isocyanate groups (by reaction with toluene diisocyanate). One of the isocyanate groups was reacted with the urethane $\mathrm{NH}$-group after which the other isocyanate group was reacted with a $\mathrm{OH}$ - or NH-group of heparin, resulting in the covalent attachment of heparin to the polyurethane surface (via the PEG spacer). ${ }^{49}$ Alternatively, the carboxyl groups of heparin can be activated with a carbodiimide after which it can react with $\mathrm{OH}$ - or $\mathrm{NH}$-groups at a polymer surface. ${ }^{47}$

A new and promising approach for the surface modification of polymers was introduced by Chapman et al. who suggested the use of Langmuir-Blodgett type layers of phospholipids to mimic (to a certain degree) the outer membrane surface of blood platelets and erythrocytes. ${ }^{50}$ Since these cells continuously interact with blood it can be expected that their blood-contacting surface (the outer leaflet of the phospholipid bilayer) is non-thrombogenic. As discussed in section 1.2 , the asymmetric distribution of phospholipids over the inner and outer leaflet of the phospholipid bilayer of platelets is lost upon activation with thrombin and collagen, resulting in the net transport of anionic phospholipids (such as phosphatidylserine) from the inner to the outer leaflet. This process turns the normally non-coagulant platelet surface into a procoagulant one. Further, liposomes (vesicles made from naturally occurring phospholipids) prepared from neutral phospholipids (such as phosphatidylcholine) are non-thrombogenic whereas liposomes containing anionic phospholipids (such as phosphatidylserine) enhance blood clotting. ${ }^{13}$

Langmuir-Blodgett films were prepared on various materials from phospholipids (phosphatidylcholines) containing diacetylene groups which were then cross-linked by UV irradiation to stabilize the phospholipid layer ${ }^{50}$ In an alternative approach Regen et al. prepared relatively stable films of phospholipids containing 
methacryloyl groups on a polyethylene surface by adsorbing phospholipid vesicles to the surface followed by UV irradiation to induce cross-linking. ${ }^{51}$ Application of these cross-linked phospholipid films as a surface coating to enhance hemocompatibility has been limited (probably since these films lack a stable attachment to the surface). $52-54$

It was suggested that the phosphorylcholine headgroup is the essential part of the phosphatidylcholine molecule responsible for its hemocompatibility. ${ }^{55}$ The research groups of Chapman and Nakabayashi have been very active in developing materials containing phosphorylcholine. Although materials with phosphorylcholine groups attached to the surface hardly resemble the highly ordered surface of a phospholipid bilayer they have been quite successful in blood-contacting applications (see below). The strongly hydrophilic nature of the zwitterionic phosphorylcholine group and the fact that it is electrically neutral could be reasons for its hemocompatibility. ${ }^{53}$

Methods were developed to couple phosphorylcholine-containing molecules to surfaces bearing hydroxyl groups (in particular glass) and carboxylic groups, ${ }^{56,57}$ and improvements in hemocompatibility were demonstrated. ${ }^{58}$ Phosphorylcholine was also incorporated in the polymer chain of polyurethanes and polyesters (methacrylate chemistry). ${ }^{59}$ A copolymer of 2-methacryloyloxyethyl phosphorylcholine (MPC) (Fig. 4) and laurylmethacrylate (LM) was used as a (physical) coating on polyvinylchloride, reducing fibrinogen adsorption and platelet adhesion/activation. ${ }^{60}$<smiles>C=C(C)C(=O)OCCOP(=O)([O-])OCC[N+](C)(C)C</smiles>

Figure 4. MPC (2-methacryloyloxyethyl phosphorylcholine).

Nakabayashi et al. have been investigating the use of copolymers of MPC and various acrylates for the preparation of hemocompatible materials. Phosphorylcholine-containing hydrogel membranes were prepared from a copolymer of MPC and butylmethacrylate (BMA). ${ }^{61}$ Platelet adhesion and activation was diminished on the copolymer poly(MPC-co-BMA) compared to polyBMA and decreased with increasing MPC content. ${ }^{62}$ It was speculated that phospholipids from blood have an affinity for the phosphorylcholine-containing polymer and could form 
an arranged layer on the surface, thereby diminishing platelet adhesion. Using DSC (differential scanning calorimetry) and ESCA (electron spectroscopy for chemical analysis) it was made plausible (in a model experiment) that phospholipids (dipalmitoyl phosphatidylcholine, DPPC) adsorbed to poly(MPC-co-BMA) in a bilayer-like structure whereas random adsorption occurred on polyBMA. ${ }^{63}$ Furthermore, albumin adsorption was considerably lower on poly(MPC-co-BMA) than on polyBMA and pre-adsorbed DPPC further diminished albumin adsorption on both surfaces (hence, both bilayer-like and randomly adsorbed DPPC diminishes albumin adsorption). The amount of protein (Alb, Fg, IgG, HMWK, factor XII, and more) adsorbed from human plasma onto poly(MPC-co-BMA) decreased with increasing MPC content. ${ }^{64}$ Platelet adsorption and activation diminished on both poly(MPC-co-BMA) and polyBMA after treatment with DPPC vesicles but considerably more so on the former. ${ }^{65}$ In contrast, pre-adsorption with dipalmitoyl phosphatidylserine (DPPS) increased platelet adsorption on poly(MPC-co-BMA) (not tested on polyBMA).

Phosphorylcholine-containing poly(MPC-co-BMA) has been used as a (physically attached) coating on polyBMA ${ }^{66}$ MPC has been used to modify the surface of Cuprophan ${ }^{(B)}$ (a cellulose membrane for dialysis) in a grafting procedure iniated by $\mathrm{Ce}^{4+}$ ions (resulting in the formation of polyMPC covalently bound to the surface). ${ }^{67}$ An MPC-containing copolymer was employed to physically coat a polyurethane, ${ }^{68}$ while another MPC-containing copolymer was blended with a polyurethane. ${ }^{69}$ In general, the MPC-containing surfaces demonstrated improved hemocompatibility indicated by a decrease in protein adsorption and/or platelet adhesion and activation.

Recently, a different approach was suggested to attach phosphorylcholine groups to a polymer surface. ${ }^{70} \mathrm{~A}$ diacyl phosphatidylcholine containing a carboxylic group at the end of one of the acyl chains was attached to the surface of aminated (by a plasma modification technique) polymers via a carbodiimide coupling scheme. Hydrophobic interactions between the free acyl chains could result in a more highly ordered structure exposing phosphorylcholine at the surface, compared to the modified surfaces described above. Platelet adhesion decreased considerably on these modified surfaces. 


\subsection{Outline of this thesis}

The aim of this study was to find an effective method for the covalent attachment of phosphorylcholine-containing molecules to a polyurethane surface in order to improve the hemocompatibility of this type of polymers.

In Chapter 2 the synthesis is described of a number of bifunctional compounds carrying a phosphorylcholine moiety at one end of the molecule and a photoreactive azidophenyl moiety at the other end. The two moieties are separated by a variablelength spacer chain consisting of ethylene glycol units. A convenient synthetic scheme and purification method was developed that allows for the rapid and safe preparation of these compounds. The photoreactive azidophenyl group can be used to couple these compounds to polymers containing weakly nucleophilic groups.

Chapter 3 provides evidence that aryl azides can indeed couple covalently to a polyurethane surface. For this purpose an aryl azide was synthesized carrying a fluorescent dimethylaminonaphthalenesulfonyl (dansyl) moiety. Irradiation with UV light resulted in the covalent coupling to a polyurethane surface which could be proven by a rapid hydrolysis experiment. Furthermore, an estimate could be made of the surface density of coupled groups.

Chapter 4 describes the preparation of two aryl azides carrying a phosphorylcholine endgroup. The procedure to couple these compounds photochemically to a polyurethane surface is delineated. The modified surfaces were characterized by contact angle and ESCA (electron spectroscopy for chemical analysis) measurements. The hemocompatibility in vitro was tested with thrombin generation tests and platelet adhesion experiments.

Chapter 5 reports on protein adsorption experiments on modified polyurethane surfaces. Polyurethane films were cast on silicon wafers after which phosphorylcholine groups were introduced by the method described in the previous chapter. Ellipsometry was used to measure adsorption of (human) fibrinogen, albumin, and high molecular weight kininogen (HMWK). The influence of preadsorbed phospholipid vesicles on protein adsorption was studied and the results were compared to protein adsorption on a phospholipid bilayer formed on silicon.

Chapter 6 discusses the results from this study. 


\section{References}

1. M.D. Lelah and S.L. Cooper, Polyurethanes in medicine, CRC Press, Boca Raton, Florida, 1986 and references therein.

2. N.A. Peppas and R. Langer, "New challenges in biomaterials," Science, 263, 17151720 (1994).

3. F.H. Silver, Biomaterials, medical devices and tissue engineering: an integrated approach, Chapman \& Hall, London, 1994.

4. B.D. Ratner, "New ideas in biomaterials science - a path to engineered biomaterials," J. Biomed. Mater. Res., 27, 837-850 (1993).

5. F.H. Silver and C. Doillon, Biocompatibility: interactions of biological and implantable materials, Volume 1: Polymers, VCH, New York, 1989.

6. M. Szycher and S.J. Lee, "Cardiovascular devices for the 1990s," J. Biomat. Appl., 8, 31-63 (1993).

7. D. Harmening Pittiglio, in Clinical hematology and fundamentals of hemostasis, D. Harmening Pittiglio and R.A. Sacher (Eds.), F.A. Davis Company, Philadelphia, 1987, Ch. 26.

8. C.T. Esmon and W.G. Owen, "Identification of an endiothelial cofactor for thrombincatalyzed activation of protein C," Proc. Natl. Acad. Sci. USA, 78, 2249-52 (1981).

9. A. Blann, "Von Willebrand factor and the endothelium in vascular disease," $B r . J$. Biomed. Sci., 50, 125-134 (1993) and references therein.

10. H.J. Chap, R.F.A. Zwaal, and L.L.M. van Deenen, "Action of highly purified phospholipases on blood platelets. Evidence for an asymmetric distribution of phospholipids in the surface membrane," Biochim. Biophys. Acta, 467, 146-164 (1977).

11. R.F.A. Zwaal and H.C. Hemker, "Blood cell membranes and haemostasis," Haemostasis, 11, 12-39 (1982).

12. E.M. Bevers, P. Comfurius, J.L.M.L. van Rijn, H.C. Hemker, and R.F.A. Zwaal, "Generation of prothrombin-converting activity and the exposure of phosphatidylserine at the outer surface of platelets," Eur. J. Biochem, 122, 429-436 (1982).

13. R.F.A. Zwaal, P. Comfurius, and L.L.M. van Deenen, "Membrane asymmetry and blood coagulation," Nature, 268, 358-360 (1977).

14. R.F.A. Zwaal, P. Comfurius, and E.M. Bevers, "Platelet procoagulant activity and microvesicle formation. Its putative role in hemostasis and thrombosis," Biochim. Biophys. Acta, 1180, 1-8 (1992).

15. E.W. Davie, K. Fujikawa, and W. Kisiel, "The coagulation cascade: initiation, maintenance, and regulation,"Biochemistry, 30, 10363-70 (1991) and references therein.

16. A.P. Kaplan and M. Silverberg, "The coagulation-kinin pathway of human plasma," Blood, 70, 1-15 (1987) and references therein.

17. Y. Nemerson, "Tissue factor and hemostasis," Blood, 71, 1-8 (1988).

18. R. Bach, R. Gentry, and Y. Nemerson, "Factor VII binding to tissue factor in reconstituted phospholipid vesicles: induction of cooperativity by phosphatidylserine," Biochemistry, 25, 4007-20 (1986). 
19. D. Gailani and G.J. Broze, "Factor XI activation in a revised model of blood coagulation," Science, 253, 909-912 (1991).

20. J.D. Andrade, in Surface and interfacial aspects of biomedical polymers. Vol. 2. Protein Adsorption, J.D. Andrade (Ed.), Plenum Press, New York, 1985, Ch. 1.

21. J.L. Brash, "The fate of fibrinogen following adsorption at the blood-biomaterial interface," Ann. N.Y. Acad. Sci., 516, 206-222 (1987).

22. R.E. Baier, "Selected methods of investigation for blood-contact surfaces," Ann. N.Y. Acad. Sci., 516, 68-77 (1987).

23. A.S. Hoffman, "Blood-biomaterial interactions" an overview," in Biomaterials: interfacial phenomena and applications (Advances in Chemistry Series 199), S.L. Cooper and N.A. Peppas (Eds.), ACS, Washington D.C., 1982, pp. 3-8.

24. R.W. Colman, C.F. Scott, A.H. Schmaier, Y.T. Wachtfogel, R.A. Pixley, and L.H. Edmunds, Jr., "Initiation of blood coagulation at artificial surfaces," Ann. N.Y. Acad. Sci., 516, 253-267 (1987).

25. L. Vroman and A.L. Adams, "Adsorption of proteins out of plasma and solutions in narrow spaces," J. Colloid Interface Sci., 111, 391-402 (1986).

26. L. Vroman, "The life of an artificial device in contact with blood: initial events and their effect on its final state," Bull. N.Y. Acad. Med., 64, 352-357 (1988).

27. J.D. Andrade and V. Hlady, "Plasma protein adsorption: the big twelve," Ann. N.Y. Acad. Sci., 516, 158-172 (1987).

28. P.A. Cuypers, G.M. Willems, H.C. Hemker, and W.T. Hermens, "Adsorption kinetics of protein mixtures: a tentative explanation of the Vroman effect, "Ann. N.Y. Acad. Sci., 516, 244-252 (1987).

29. W. Norde, "Adsorption of proteins at solid surfaces," in Adhesion and adsorption of polymer. Vol. 2., L.-H.Y. Lee (Ed.), Plenum Press, New York, 1980, pp. 801-826.

30. S. Uniyal and J.L. Brash, "Patterns of adsorption of proteins from human plasma onto foreign surfaces," Thromb. Haemostas., 47, 249-259 (1982).

31. E.W. Salzman, J.N. Lindon, G. McNamana, and J.A. Ware, "Role of fibrinogen in activation of platelets by artificial surfaces," Ann. N.Y. Acad. Sci., 516, 184-195 (1987).

32. J.N. Lindon, G. McNamana, L. Kushner, E.W. Merrill, and E.W. Salzman, "Does the conformation of adsorbed fibrinogen dictate platelet interactions with artificial surfaces?" Blood, 68, 355-362 (1986).

33. E.W. Merrill, "Distinctions and correspondences among surfaces contacting blood," Anu. N.Y. Acad. Sci., 516, 196-203 (1987).

34. E.W. Merrill and E.W. Salzman, "Polyethylene oxide as a biomaterial," ASAIO J., 6, 60-64 (1983).

35. G.H. Engbers and J. Feijen, "Current techniques to improve the blood compatibility of biomaterial surfaces, "Int. J. Artif. Organs, 14, 199-215 (1991) and references therein.

36. Y. Ikada, "Surface modification of polymers for medical applications," Biomaterials, $15,725-736$ (1994) and references therein.

37. C.H. Bamford and K.G. Al-Lamee, "Chemical methods for improving the haemocompatibility of synthetic polymers," Clin. Mater., 10, 243-261 (1992) and references therein. 
38. E.W. Merrill, E.W. Salzman, V. Sa Da Costa, D. Brier-Russell, A. Dincer, P. Pape, and J.N. Lindon, "Platelet retention on polymer surfaces," in Biomaterials: interfacial phenomena and applications (Advances in Chemistry Series 199), S.L. Cooper and N.A. Peppas (Eds.), ACS, Washington D.C., 1982, pp. 35-42.

39. Y. Mori, S. Nagaoka, H. Takiuchi, T. Kikuchi, N. Noguchi, H. Tanzawa, and Y. Noishiki, "A new antithrombogenic material with long polyethylene oxide chains," Trans. Am. Soc. Artif. Intern. Organs, 28, 459-463 (1982).

40. N.P. Desai and J.A. Hubbell, "Solution technique to incorporate polyethylene oxide and other water-soluble polymers into surfaces of polymeric biomaterials," Biomaterials, 12, 144-153 (1991).

41. V. Sa Da Costa, D. Brier-Russell, E.W. Salzman, and E.W. Merrill, "ESCA studies of polyurethanes: blood platelet activation in relation to surface composition, ${ }^{\text {" }} \mathrm{J}$. Colloid Interface Sci., 80, 445-452 (1981).

42. B.H.J. Hofstee and N.F. Otillio, "Non-ionic adsorption chromatography of proteins," J. Chromatogr., 159, 57-69 (1978).

43. M.S. Munro, A.J. Quattrone, S.R. Ellsworth, P. Kulkarni, and R.C. Eberhart, "Alkyl substituted polymers with enhanced albumin affinity," Trans. Am. Soc. Artif. Intern. Organs, 27, 499-503 (1981).

44. R.C. Eberhart, M.S. Munro, J.R. Frautschi, M. Lubin, F.J. Clubb, and C.W. Miller, "Influence of endogenous albumin binding on blood-material interactions," Ann. N.Y. Acad. Sci., 516, 78-95 (1987).

45. W.G. Pitt and S.L. Cooper, "Albumin adsorption on alkyl chain derivatized polyurethane. I. The effect of C-18 alkylation," J. Biomed. Mater. Res., 22, 359-382 (1988).

46. K. Kottke-Marchant, J.M. Anderson, Y. Umemura, and R.E. Marchant, "Effect of albumin coating on the in vitro blood compatibility of Dacron arterial prostheses," Biomaterials, 10, 147-155 (1989).

47. C.D. Ebert, E.S. Lee, J. Deneris, and S.W. Kim, "The anticoagulant activity of derivatized and immobilized heparins," in Biomaterials: interfacial phenomena and applications (Advances in Chemistry Series 199), S.L. Cooper and N.A. Peppas (Eds.), ACS, Washington D.C., 1982, pp. 162-176.

48. C.D. Ebert and S.W. Kim, "Immobilized heparin spacer arm effect on biological interactions," Thromb. Res., 26, 43-57 (1982).

49. K.D. Park, T. Okano, C. Nojiri, and S.W. Kim, "Heparin immobilization onto segmented polyurethaneurea surfaces - effect of hydrophilic spacers," J. Biomed. Mater. Res., 22, 977-992 (1988).

50. O. Albrecht, D.S. Johnston, C. Villaverde, and D. Chapman, "Stable biomembrane surfaces formed by phospholipid polymers," Biochim. Biophys. Acta, 687, 165-169 (1982).

51. S.L. Regen, P. Kirszensztejn, and A. Singh, "Polymer-supported membranes. A new approach for modifying polymer surfaces," Macromolecules, 16, 335-338(1983).

52. R. le R. Bird, B. Hall, D. Chapman, and K.E.F. Hobbs, "Material thromboelastography: an assessment of phosphorylcholine compounds as models for biomaterials," Thromb. Res., 51, 471-483 (1988). 
53. D. Chapman, "Biomembranes and new hemocompatible materials," Langmuir, 9, 3945 (1993).

54. D. Chapman, European Patent $32622,1979$.

55. J.A. Hayward and D. Chapman, "Biomembrane surfaces as models for polymer design: the potential for haemocompatibility," Biomaterials, 5, 135-142 (1984).

56. A.A. Durrani, J.A. Hayward, and D. Chapman, "Biomembranes as models for polymer surfaces. II. The syntheses of reactive species for covalent coupling of phosphorylcholine to polymer surfaces," Biomaterials, 7, 121-125 (1986).

57. J.A. Hayward, A.A. Durrani, C.J. Shelton, D.C. Lee, and D. Chapman, "Biomembranes as models for polymer surfaces. III. Characterization of phosphoryllcholine surface covalently bound to glass," Biomaterials, 7, 126-131 (11986).

58. D. Chapman and A.A. Durrani, European Patent $157469,1984$.

59. A.A. Durrani, European Patent 275293, 1986.

60. E.J. Campbell, V. O'Byrne ${ }_{x}$ P.W. Stratford, I. Quirk, T.A. Vick, M.C. Wiles, and Y. Yianni, "Biocompatible surfaces using methacryloylphosphorylcholine laurylmethacrylate copolymer," ASAIO $J_{.}, 40$, M853-M857 (1994).

61. K. Ishihara, T. Ueda, and $\mathbf{N}$. Nakabayashi, "Preparation of phospholipid polymers and their properties as polymer hydrogel membranes," Polym. J., 22, 355-360 (1990).

62. K. Ishihara, R. Aragaki, T. Ueda, A. Watanabe, and N. Nakabayashi, "Reduced thrombogenicity of polymers having phospholipid polar groups," $J$. Biomed. Mater. Res., 24, 1069-77 (1990).

63. T. Ueda, A. Watanabe, K. Ishihara, and N. Nakabayashi, "Protein adsorption on biomedical polymers with a phosphorylcholine moiety adsorbed with phospholipid," J. Biomater. Sci. Polymer Edn, 3, 185-194 (1991).

64. K. Ishihara, N.P. Ziats, B.P. Tierney. N. Nakabayashi, and J.M. Anderson, "Protein adsorption from human plasma is reduced on phospholipid polymers," $J$. Biomed. Mater, Res., 25, 1397-1407 (1991).

65. K. Ishihara, H. Oshida, Y. Endo, A. Watanabe, T. Ueda, and N. Nakabayashi, "Effects of phospholipid adsorption on nonthrombogenicity of polymer with phospholipid polar group," J. Biomed. Mater. Res., 27, 1309-1314 (1993).

66. K. Ishihara, T. Tsuji, T. Kurosaki, and N. Nakabayashi, "Hemocompatibility on graft copolymers composed of poly(2-methacryloyloxyethyl phosphorylcholine) side chain and poly (n-butylmethacrylate) backbone," J. Biomed. Mater. Res., 28, 225-232 (1994).

67. K. Ishihara, N. Nakabayashi, K. Fukumoto, and J. Aaki, "Improvement of blood compatibility on cellulose dialysis membrane. I. Grafting of 2-methacryloyloxyethyl phosphorylcholine on to a cellulose membrane surface," Biomaterials, 13, 145-149 (1992).

68. K. Ishihara, H. Hanyuda, and N. Nakabayashi, "Synthesis of phospholipid polymers having a urethane bond in the side chain as coating material on segmented polyurethane and their platelet adhesion-resistant properties," Biomaterials, 16, 873879 (1992). 
69. K. Ishihara, S. Tanaka, N. Furukawa, K. Kurita, and N. Nakabayashi, "Improved blood compatibility of segmented polyurethanes by polymeric additives having phospholipid polar groups. I. Molecular design of polymeric additives and their functions," J. Biomed. Mater. Res., 32, 391-399 (1996).

70. A.S. Köhler, P.J. Parks, D.L. Mooradian, G.H.R. Rao. and L.T. Furcht, "Platelet adhesion to novel phospholipid materials: Modified phosphatidylcholine covalently immobilized to silica, polypropylene, and PTFE materials," J. Biomed. Mater. Res., 32, 237-242 (1996). 



\title{
Synthesis of a Homologous Series of Bifunctional Photoreactive Compounds Carrying a Phosphoryl- choline Moiety for the Surface Modification of Polymeric Biomaterials*
}

\begin{abstract}
Three novel birunctional compounds $(1 \mathrm{a}-\mathrm{c})$ have been synthesized that can be used for the photochemical surface modification of polymeric materials with the aim of improving their blood compatibility. The conjugate compounds consist of: (i) a photoreactive azidopheny] moiety, (ii) a "blood compatible" phosphorylcholine moiety, and (iii) a variable-length spacer chain separating (i) and (ii). 4-Azidophenethyl 2-(trimethylammonium)ethyl phosphate (1a) was prepared in moderate yield ( $38 \%$ ) by a five-step procedure starting from 4-aminophenethyl alcohol. First, the amino group was converted into an azido group by a diazotation reaction followed by substitution with azide ion. Reaction with phosphorus oxychloride followed by 2-(methylamino)ethanol gave 2-(4-azidophenethoxy)-3-methyl-2oxo-1,3,2-oxazaphospholidine (6a). Hydrolysis with dilute acid followed by methylation with dimethyl sulfate yielded target compound 1a. For the syntheses of the two higher homologs (1b and 1c) bromides were prepared from trityl protected ethylene glycol and triethylene glycol. These spacer molecules were coupled to the azido alcohols via a Williamson reaction. After deprotection the same reaction sequence as described for the synthesis of $1 \mathrm{a}$ yielded target compounds $\mathbf{1 b}$ and $\mathbf{1 c}$.
\end{abstract}

"A.P. van der Heiden, R.T. Boaron, and L.H. Koole, submitted for publication. 


\section{Introduction}

Bifunctional molecules containing an azidophenyl moiety are widely employed as photoaffinity labeling reagents in biochemistry. ${ }^{1,2}$ Irradiation with UV light easily converts the azide into a short-lived intermediate that can react with a targeted site of an enzyme molecule, introducing the desired label. These conjugate compounds can also be employed as surface modifying reagents, an application which is rather new but looks promising. ${ }^{3-5}$ Ideally, surface modification of polymeric materials changes their surface properties while maintaining the bulk properties. This approach is used extensively in the search for new biomaterials that can be applied in the human body. ${ }^{6-8}$

Many polymers can be selected for the use as a biomaterial on the basis of their mechanical properties. However, their surface properties (e.g. hydrophobicity, electrical charge) often prevent the successful application of these polymers as a biomaterial. 9 The introduction of selected functional groups onto the surface of a polymer can impart the desired surface properties. Aryl azides can be used to introduce these functional groups onto a surface, since they are sufficiently reactive to form covalent bonds with nucleophilic groups at a polymer surface (such as $\mathrm{NH}_{2}$, $\mathrm{NH}$, and $\mathrm{OH}$ ) or even to form insertion compounds with $\mathrm{C}-\mathrm{H}$ groups (via a radical mechanism). ${ }^{10}$ A recent study provided unequivocal proof for the covalent attachment of conjugate molecules containing a azidophenyl moiety to a poly(ether urethane) (PEU) surface. ${ }^{11}$ There are several advantages to the use of aryl azides for surface modification in comparison to the use of other reactive compounds: they are relatively easily synthesized, very stable on storage, and very reactive once activated by UV irradiation.

In this laboratory the photoreactive azidophenyl group has been used to attach theophylline, ${ }^{12}$ dipyridamole, ${ }^{13}$ and phosphorylcholine (PC) groups (Ch. 4$)^{14}$ to the surface of PEU (Fig. 1). This polymer has the desired mechanical (bulk) properties for the manufacture of vascular grafts, ${ }^{15}$ but for the long-term application of these grafts the blood compatibility of the material's surface has to be improved. ${ }^{6} \mathrm{PC}$ groups could be used for this purpose, as was originally proposed by Hayward. ${ }^{16}$ Later, the idea of immobilizing PC groups on polymeric surfaces was also applied by others. ${ }^{17-19}$ The idea is based upon the observation that the outer membrane leaflet of 
intact blood cells (such as red blood cells) mainly consists of PC-containing phospholipids (e.g. phosphatidylcholine) which provide a natural non-thrombogenic surface.

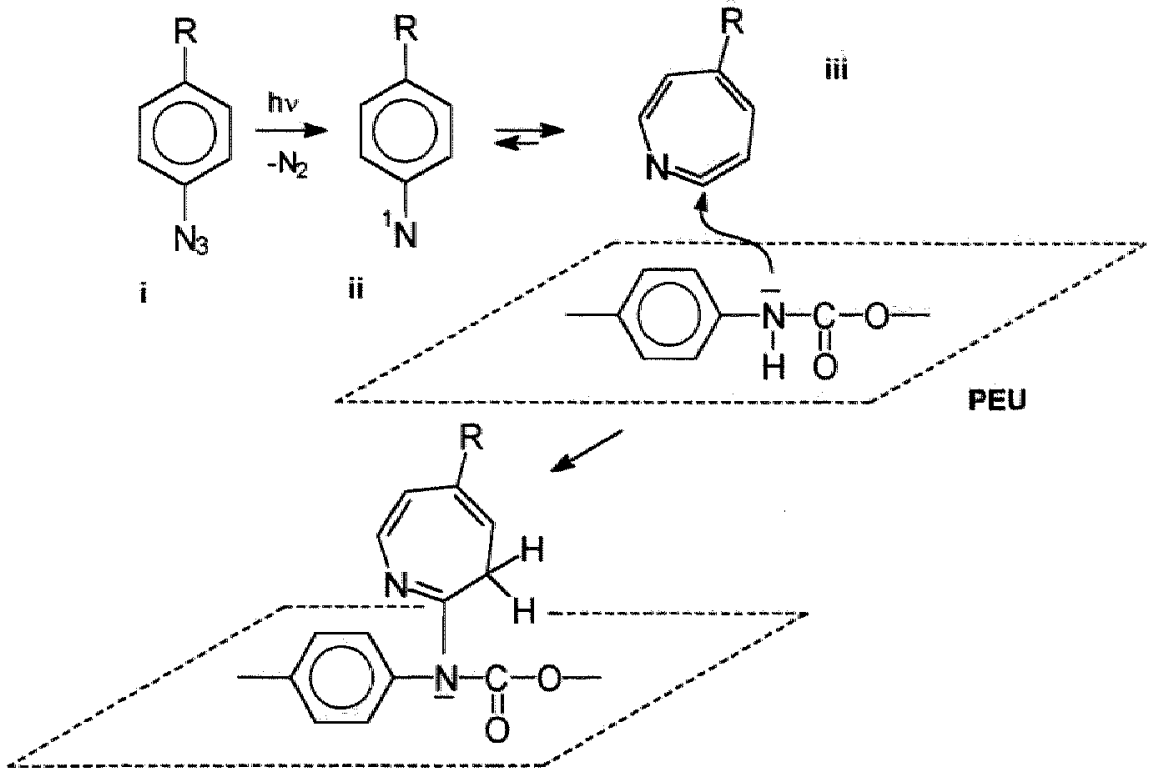

Figure 1. The photochemical reaction between an aryl azide and a poly(ether urethane) surface. UV irradiation converts azide $\mathbf{i}$ into the reactive singlet nitrene ii. After rearrangement into didehydroazepine iii coupling can occur with weakly nucleophillic groups at the polymer surface.

Here, the synthesis is described of three new photoreactive conjugates $(1 \mathrm{a}-\mathrm{c})$ carrying a PC endgroup. The difference between the three compounds is the length of the spacer that separates the PC group from the azidophenyl group. It is hypothesized that the length and the flexibility of the spacer chain plays a role in facilitating the formation of an ordered structure of immobilized PC groups; it is well known that PC groups tend to align themselves in a head-to-tail fashion. The spacer chain was constructed from ethylene glycol units, since it is well known that poly(ethylene glycol) groups coupled to a polymer surface improve the blood compatibility by decreasing protein adsorption. ${ }^{6}$ 


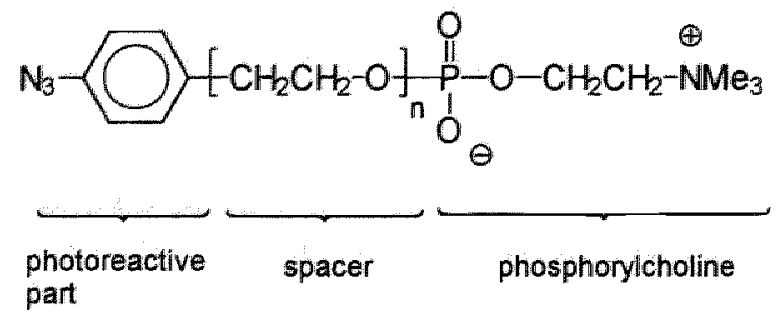

$$
\begin{aligned}
& \text { 1a } n=1 \\
& \text { 1b } n=2 \\
& \text { 1c } n=4
\end{aligned}
$$

\section{Experimental}

\section{General}

NMR spectra were recorded on a Varian Unity-Plus $400 \mathrm{MHz}$ spectrometer

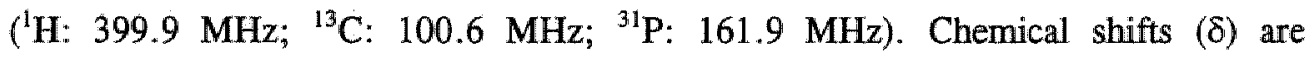
expressed in ppm downfield from internal tetramethylsilane $\left({ }^{1} \mathrm{H}\right.$ and ${ }^{13} \mathrm{C}$ NMR) or external $85 \%$ phosphoric acid ( ${ }^{31} \mathrm{P}$ NMR). Column chromatography was carried out with Merck silica gel $60(0.063-0.200 \mathrm{~mm})$. TLC was performed with Merck silica gel $60 \mathrm{~F}_{254}$ on aluminium sheets. Tetrahydrofuran and diethylether were distilled from $\mathrm{CaH}_{2}$ prior to use. Pyridine was distilled from $\mathrm{KOH}$ and triethylamine from $\mathrm{CaH}_{2}$. Ethylene glycol and triethylene glycol were dried on a column of molecular sieves (4 $\AA$ ). 2-(Methylamino)ethanol was distilled from $\mathrm{CaH}_{2}$ under reduced pressure and stored under nitrogen. Ethyl acetate, petroleumether (PE, bp 40-65 ${ }^{\circ} \mathrm{C}$ ), n-hexane, dichloromethane, toluene, acetonitrile, acetone, and methanol were of p.a. quality and used as received.

\section{Synthesis}

4-Axidophenethyl alcohol (2). 4-Aminophenethyl alcohol (10.0 g, $73.0 \mathrm{mmol})$ was dissolved in a mixture of $60 \mathrm{~mL}$ of water and $15 \mathrm{~mL}$ of $37 \%$ hydrochloric acid $(174 \mathrm{mmol}$ of $\mathrm{HCl})$. The solution was cooled to $0^{\circ} \mathrm{C}$ with an ice bath and a solution of sodium nitrite $(5.04 \mathrm{~g} ; 73.0 \mathrm{mmol})$ in $20 \mathrm{~mL}$ of water was added at such a rate 
that the temperature did not exceed $5^{\circ} \mathrm{C}$. Next, a solution of sodium azide $(5.27 \mathrm{~g}$; $81.0 \mathrm{mmol}$ ) in $20 \mathrm{~mL}$ of water was added slowly, keeping the temperature below 5 ${ }^{\circ} \mathrm{C}$. After stirring for $1 \mathrm{~h}$ the reaction mixture was extracted with ether. The organic layer was washed with $1 \mathrm{M}$ potassium carbonate solution and dried over magnesium sulfate. Evaporation of the solvent yielded the pure product as a yellow oil $(10.7 \mathrm{~g}$; $90 \%), \mathrm{R}_{\mathrm{f}}\left(\mathrm{CH}_{2} \mathrm{Cl}_{2}\right) \quad 0.16 ;{ }^{1} \mathrm{H}$ NMR $\left(\mathrm{CDCl}_{3}\right) \delta 1.52(1 \mathrm{H}, \mathrm{s}, \mathrm{OH}), 2.86(2 \mathrm{H}, \mathrm{t}$, $\left.\mathrm{PhCH}_{2}\right), 3.85\left(2 \mathrm{H}\right.$, br t, $\left.\mathrm{CH}_{2} \mathrm{OH}\right), 6.98(2 \mathrm{H}, \mathrm{m}$, ar $\mathrm{H}), 7.22(2 \mathrm{H}, \mathrm{m}$, ar $\mathrm{H}) ;{ }^{13} \mathrm{C}$ NMR $\left(\mathrm{CDCl}_{3}\right) \delta 38.4\left(\mathrm{PhCH}_{2}\right), 63.5\left(\mathrm{CH}_{2} \mathrm{O}\right), 119.1$ (2 ar C), $130.3(2$ ar C), 135.3 $(\operatorname{ar~C}), 138.2(\operatorname{ar~C}) ; \operatorname{IR}(\mathrm{KBr}) \vee\left(\mathrm{cm}^{-1}\right): 3340(\mathrm{OH}), 2110\left(\mathrm{~N}_{3}\right)$.

2-Bromoethyl trityl ether (3b). Excess ethylene glycol (24.8 g; $400 \mathrm{mmol}$ ), trityl chloride $(13.9 \mathrm{~g} ; 50 \mathrm{mmol})$ and DMAP $(0.30 \mathrm{~g} ; 2.5 \mathrm{mmol})$ were dissolved in $50 \mathrm{~mL}$ of pyridine. After stirring for $16 \mathrm{~h}$ pyridine was evaporated and the last traces of pyridine were removed by coevaporation with toluene (3 times). The solid residue was dissolved in dichloromethane and washed with saturated $\mathrm{NaHCO}_{3}$ and water. The organic layer was dried over magnesium sulfate. After evaporation of the solvent the crude product was coevaporated with toluene, methanol, and dichloromethane. The pure compound was obtained after recrystallization from hexane/chloroform 5:1. This furnished ethylene glycol monotrityl ether as a white solid $\left(9.45 \mathrm{~g}, 62 \%\right.$, based on trityl cbloride); ${ }^{1} \mathrm{H} \mathrm{NMR}\left(\mathrm{CDCl}_{3}\right) \delta 2.02(1 \mathrm{H}, \mathrm{t}, \mathrm{OH})$, $3.27\left(2 \mathrm{H}, \mathrm{t}, \mathrm{CH}_{2} \mathrm{OC}\right), 3.76\left(2 \mathrm{H}\right.$, br q, $\left.\mathrm{CH}_{2} \mathrm{OH}\right), 7.30(9 \mathrm{H}, \mathrm{m}$, ar H), $7.47(6 \mathrm{H}, \mathrm{m}$, ar $\mathrm{H}$ ); ${ }^{13} \mathrm{C}$ NMR $\left(\mathrm{CDCl}_{3}\right) \delta 62.4$ and $64.7\left(2 \times \mathrm{CH}_{2}\right), 86.6$ (quat $\mathrm{C}$ ), 127.0 (ar $\mathrm{C}$, para), 127.8 and 128.6 (ar C, ortho and meta), 143.8 (ar C, ipso).

Triphenylphosphine (5.16 $\mathrm{g} ; 19.3 \mathrm{mmol}$ ) was dissolved in $30 \mathrm{~mL}$ of dichloromethane. A solution of bromine $(3.20 \mathrm{~g} ; 20.0 \mathrm{mmol})$ in $15 \mathrm{~mL}$ of dichloromethane was added dropwise until a small excess of bromine was present in the reaction mixture (yellow solution). This excess was removed by adding a small quantity of triphenylphosphine. After adding triethylamine $(2.43 \mathrm{~g} ; 24.0 \mathrm{mmol})$ a solution of ethylene glycol monotrityl ether $(5.00 \mathrm{~g} ; 16.0 \mathrm{mmol})$ in $15 \mathrm{~mL}$ of dichloromethane was added dropwise. After $30 \mathrm{~min}$ the mixture was evaporated to dryness. The residue was dissolved in ether and washed with water. Two grains of iodine were added during the wash step to catalyze the conversion of excess triphenylphosphine into triphenylphosphine oxide. The organic layer was further 
washed with $1 \mathrm{M}$ sodium thiosulfate and dried over magnesium sulfate. After evaporation of the solvent the crude product was purified by column chromatography (dichloromethane, $\mathrm{R}_{\mathrm{f}}=0.75$ ). Compound $\mathbf{3 b}$ was obtained as a white solid $(5.29 \mathrm{~g}$; $90 \%) ;{ }^{\mathrm{H}} \mathrm{NMR}\left(\mathrm{CDCl}_{3}\right) \delta 3.45\left(4 \mathrm{H}, \mathrm{m}, 2 \times \mathrm{CH}_{2}\right), 7.30(9 \mathrm{H}, \mathrm{m}, \mathrm{ar} \mathrm{H}), 7.49(6 \mathrm{H}$, $\mathrm{m}$, ar H); ${ }^{13} \mathrm{C} \mathrm{NMR}\left(\mathrm{CDCl}_{3}\right) \& 31.0\left(\mathrm{CH}_{2} \mathrm{Br}\right), 63.7\left(\mathrm{CH}_{2} \mathrm{O}\right), 86.8$ (quat $\mathrm{C}$ ), 127.1, 127.8, and 128.6 (ar C), 143.7 (ar C, ipso); IR (KBr) v $\left(\mathrm{cm}^{-1}\right)$ : $570(\mathrm{CBr})$.

2-(2-(2-Bromoethoxy)ethoxy)ethyl trityl ether (3c). To a solution of excess triethylene glycol $(37.50 \mathrm{~g} ; 250 \mathrm{mmol})$ and DMAP $(0.31 \mathrm{~g} ; 2.51 \mathrm{mmol})$ in $50 \mathrm{~mL}$ of pyridine, triphenylmethyl chloride $(6.97 \mathrm{~g} ; 25.0 \mathrm{mmol})$ was added in small quantities during three $\mathrm{h}$. After stirring for $16 \mathrm{~h}$ the reaction mixture was processed as described for the synthesis of ethylene glycol monotrityl ether. Pure triethylene glycol monotrityl ether was obtained after column chromatography (EtOAc/PE 1:1 $\rightarrow$ EtOAc, $\mathrm{Rf}_{\mathrm{f}}=0.47 \mathrm{in}$ EtOAc) as a viscous oil $(8.86 \mathrm{~g} ; 90 \%) ;{ }^{1} \mathrm{H} \mathrm{NMR}\left(\mathrm{CDCl}_{3}\right) \delta$ $2.95\left(1 \mathrm{H}\right.$, br s, OH), $3.25\left(2 \mathrm{H}, \mathrm{t}, \mathrm{CH}_{2} \mathrm{OCPh}_{3}\right), 3.58\left(2 \mathrm{H}, \mathrm{t}, \mathrm{CH}_{2} \mathrm{O}\right), 3.65(8 \mathrm{H}, \mathrm{m}, 4$ $\left.\times \mathrm{CH}_{2} \mathrm{O}\right), 7.20(3 \mathrm{H}, \mathrm{m}$, ar H$), 7.28(6 \mathrm{H}, \mathrm{m}$, ar $\mathrm{H}), 7.48(6 \mathrm{H}, \mathrm{m}$, ar H) .

Triphenylphosphine $(7.08 \mathrm{~g} ; 27.0 \mathrm{mmol})$ was dissolved in $40 \mathrm{~mL}$ of dichloromethane. A solution of bromine $(4.60 \mathrm{~g} ; 28.8 \mathrm{mmol})$ in $20 \mathrm{~mL}$ of dichloromethane was added dropwise until a small excess of bromine was present in the reaction mixture (yellow solution). This excess was removed by adding a small quantity of triphenylphosphine. After adding triethylamine $(4.05 \mathrm{~g} ; 40 \mathrm{mmol}$ ) a solution of triethylene glycol monotrityl ether $(8.76 \mathrm{~g} ; 22.3 \mathrm{mmol})$ in $20 \mathrm{~mL}$ of dichloromethane was added dropwise. After $30 \mathrm{~min}$ the reaction mixture was evaporated to dryness and processed as described for the synthesis of $\mathbf{3 b}$. The crude product was purified by column chromatography (dichloromethane, $R_{f}=0.54$ ). This afforded compound $3 \mathrm{c}$ as a white solid. $(9.31 \mathrm{~g}, 91 \%) ;{ }^{1} \mathrm{H}$ NMR $\left(\mathrm{CDCl}_{3}\right) \delta 3.25$ $\left(2 \mathrm{H}, \mathrm{t}, \mathrm{CH}_{2} \mathrm{OCPh}_{3}\right), 3.48\left(2 \mathrm{H}, \mathrm{t}, \mathrm{CH}_{2}\right), 3.70\left(6 \mathrm{H}, \mathrm{m}, 3 \times \mathrm{CH}_{2}\right), 3.83\left(2 \mathrm{H}, \mathrm{t}, \mathrm{CH}_{2}\right)$, $7.27(9 \mathrm{H}, \mathrm{m}$, ar $\mathrm{H}), 7.48(6 \mathrm{H}, \mathrm{m}$, ar $\mathrm{H}) ;{ }^{13} \mathrm{C} \mathrm{NMR}\left(\mathrm{CDCl}_{3}\right) \delta 30.3\left(\mathrm{CH}_{2} \mathrm{Br}\right), 63.3$, $70.6,70.7,70.8$, and $71.2\left(5 \times \mathrm{CH}_{2} \mathrm{O}\right.$ ), 86.6 (quat $\mathrm{C}$ ), 126.9, 127.8, and 128.7 (ar C), 144.0 (ar C, ipso).

2-(4-Azidophenethoxy)ethyl trityl ether (4b). A $60 \%$ w/w dispersion of $\mathrm{NaH}$ in mineral oil $(0.80 \mathrm{~g} ; 20.0 \mathrm{mmol} \mathrm{NaH})$ was washed with hexane and added to a 
solution of alcohol $2(1.45 \mathrm{~g} ; 8.90 \mathrm{mmol})$ in $40 \mathrm{~mL}$ of dry THF. After $30 \mathrm{~min}$ of ultrasonication bromide $3 \mathbf{b}(3.60 \mathrm{~g} ; 9.80 \mathrm{mmol})$ was added. After stirring for $16 \mathrm{~h}$ the reaction mixture was poured into saturated $\mathrm{NH}_{4} \mathrm{Cl}$ and extracted with ethyl acetate. The organic layer was dried over magnesium sulfate. After evaporation of the solvent the crude product was purified by column chromatography $\left(\mathrm{CH}_{2} \mathrm{Cl}_{2} / \mathrm{PE}\right.$ $3: 7 \rightarrow \mathrm{CH}_{2} \mathrm{Cl}_{2}, \mathrm{R}_{\mathrm{f}}=0.09$ in $\left.\mathrm{CH}_{2} \mathrm{Cl}_{2} / \mathrm{PE} 3: 7\right)$. This afforded compound $4 \mathrm{~b}$ as a yellow oil $(2.69 \mathrm{~g}, 67 \%)$; ${ }^{1} \mathrm{H}$ NMR $\left(\mathrm{CDCl}_{3}\right) \delta 2.90\left(2 \mathrm{H}, \mathrm{t}, \mathrm{PhCH}_{2}\right), 3.22(2 \mathrm{H}, \mathrm{t}$, $\left.\mathrm{CH}_{2} \mathrm{OCPh}_{3}\right), 3.60\left(2 \mathrm{H}, \mathrm{t}, \mathrm{CH}_{2} \mathrm{CH}_{2} \mathrm{OCPh}_{3}\right), 3.70\left(2 \mathrm{H}, \mathrm{t}, \mathrm{PhCH}_{2} \mathrm{CH}_{2} \mathrm{O}\right), 6.93(2 \mathrm{H}$, $\left.\mathrm{m}, \mathrm{PhN}_{3}\right), 7.28\left(11 \mathrm{H}, \mathrm{m}, 9 \mathrm{H}\right.$ from trityl and $2 \mathrm{H}$ from $\left.\mathrm{PhN}_{3}\right), 7.45(6 \mathrm{H}, \mathrm{m}$, trityl); ${ }^{13} \mathrm{C} \mathrm{NMR}\left(\mathrm{CDCl}_{3}\right) \delta 35.6\left(\mathrm{PhCH}_{2}\right), 63.2\left(\mathrm{CH}_{2} \mathrm{OCPh}_{3}\right), 70.3\left(\mathrm{CH}_{2} \mathrm{CH}_{2} \mathrm{OCPh}_{3}\right), 71.9$ $\left(\mathrm{PhCH}_{2} \mathrm{CH}_{2} \mathrm{O}\right.$ ), 86.4 (quat $\mathrm{C}$ ), $118.8\left(2 \mathrm{C}, \mathrm{PhN}_{3}\right), 126.8,127.7$, and 128.6 (trityl), $130.2\left(2 \mathrm{C}, \mathrm{PhN}_{3}\right), 136.0$ and $137.7\left(2 \mathrm{C}, \mathrm{PhN}_{3}\right), 144.0$ (trityl, ipso).

2-(2-(2-(4-Azidophenethoxy)ethoxy)ethoxy)ethyl trityl ether (4c). A $60 \%$ w/w dispersion of $\mathrm{NaH}$ in mineral oil $(0.88 \mathrm{~g} ; 22.0 \mathrm{mmol} \mathrm{NaH})$ was washed with hexane and added to a solution of alcohol $2(1.50 \mathrm{~g} ; 9.20 \mathrm{mmoll})$ in $40 \mathrm{~mL}$ of dry THF. After $30 \mathrm{~min}$ of uitrasonication bromide $3 \mathrm{c}(5.00 \mathrm{~g} ; 11.0 \mathrm{mmol})$ was added. After stirring for $16 \mathrm{~h}$ the reaction mixture was processed as described for the synthesis of $\mathbf{4 b}$. The crude product was purified by column chromatography $(0 \rightarrow$ $20 \%$ EtOAc in PE), affording compound $4 \mathrm{c}$ as a yellow oil. $(2.84 \mathrm{~g}, 58 \%) ;{ }^{1} \mathrm{H}$ $\operatorname{NMR}\left(\mathrm{CDCl}_{3}\right) \& 2.87\left(2 \mathrm{H}, \mathrm{t}, \mathrm{PhCH}_{2}\right), 3.25\left(2 \mathrm{H}, \mathrm{t}, \mathrm{CH}_{2} \mathrm{OCPh}_{3}\right) 3.67(12 \mathrm{H}, \mathrm{m}, 6 \times$ $\left.\mathrm{CH}_{2} \mathrm{O}\right), 6.92\left(2 \mathrm{H}, \mathrm{m}, \mathrm{PhN}_{3}\right), 7.23\left(11 \mathrm{H}, \mathrm{m}, 9 \mathrm{H}\right.$ from trityl and $2 \mathrm{H}$ from $\left.\mathrm{PhN}_{3}\right)$, $7.48\left(6 \mathrm{H}, \mathrm{m}\right.$, trityl); ${ }^{13} \mathrm{C} \mathrm{NMR}\left(\mathrm{CDCl}_{3}\right) 835.5\left(\mathrm{PhCH}_{2}\right), 63.3\left(\mathrm{CH}_{2} \mathrm{OCPh}_{3}\right), 69.8$, $70.3,70.6,70.7,70.8$, and $72.1\left(6 \times \mathrm{CH}_{2} \mathrm{O}\right), 86.5$ (quat C), $118.9\left(2 \mathrm{C}, \mathrm{PhN}_{3}\right)$, 126.9, 127.7, and 128.7 (trityl), $130.2\left(2 \mathrm{C}, \mathrm{PhN}_{3}\right), 135.8$ and $137.8\left(2 \mathrm{C}, \mathrm{PhN}_{3}\right)$, 144. 1 (trityl, ipso).

2-(4-Azidophenethoxy)ethanol (5b). Zinc bromide $(3.40 \mathrm{~g} ; 15.1 \mathrm{mmol})$ was added to a solution of trityl ether $4 \mathbf{b}(2.76 \mathrm{~g} ; 6.10 \mathrm{mmol})$ in $10 \mathrm{~mL}$ of dichloromethane/methanol 8:2 v/v. After stirring for 15 min the reaction mixture was evaporated to dryness. The residue was dissolved in ethyl acetate and washed with $0.1 \mathrm{M} \mathrm{HCl}$, saturated $\mathrm{Na}_{2} \mathrm{CO}_{3}$, and saturated $\mathrm{NaCl}$, successively. After drying 
over magnesium sulfate the solvent was evaporated. The crude product was purified by column chromatography $\left(\mathrm{CH}_{2} \mathrm{Cl}_{2} /\right.$ EtOAc $8: 2 \rightarrow$ EtOAc $_{y} \mathrm{R}_{\mathrm{f}}=0.43$ in EtOAc). This yielded compound $5 \mathrm{~b}$ as a yellow oil. $(1.00 \mathrm{~g}, 79 \%) ;{ }^{1} \mathrm{H} \mathrm{NMR}\left(\mathrm{CDCl}_{3}\right) \delta 1.95$ $\left(1 \mathrm{H}\right.$, br t, OH), $2.88\left(2 \mathrm{H}, \mathrm{t}, \mathrm{PhCH}_{2}\right), 3.55\left(2 \mathrm{H}, \mathrm{m}, \mathrm{OCH}_{2} \mathrm{CH}_{2} \mathrm{OH}\right), 3.68(2 \mathrm{H}, \mathrm{t}$, $\left.\mathrm{PhCH}_{2} \mathrm{CH}_{2} \mathrm{O}\right), 3.71\left(2 \mathrm{H}, \mathrm{m}, \mathrm{CH}_{2} \mathrm{OH}\right), 6.97(2 \mathrm{H}, \mathrm{m}$, ar $\mathrm{H}), 7.21(2 \mathrm{H}, \mathrm{m}$, ar $\mathrm{H}) ;{ }^{13} \mathrm{C}$ NMR $\left(\mathrm{CDCl}_{3}\right)$ \& $35.6\left(\mathrm{PhCH}_{2}\right), 61.7\left(\mathrm{CH}_{2} \mathrm{OH}\right), 71.8\left(2 \times \mathrm{CH}_{2} \mathrm{O}\right), 118.9,130.1$, 135.6 , and 138.0 (ar C).

2-(2-(2-(4-Azidophenethoxy)ethoxy)ethoxy)ethanol (5c). Zinc bromide (2.27 $\mathrm{g} ; 10.1 \mathrm{mmol})$ was added to a solution of trityl ether $4 \mathrm{c}(2.69 \mathrm{~g} ; 5.00 \mathrm{mmol})$ in 10 $\mathrm{mil}$ of dichloromethane/methanol $8: 2 \mathrm{v} / \mathrm{v}$. After stirring for $15 \mathrm{~min}$ the reaction mixture was processed as described for the synthesis of $\mathbf{5 b}$. The crude product was purified by column chromatography $\left(0 \rightarrow 5 \% \mathrm{MeOH}\right.$ in $\left.\mathrm{CH}_{2} \mathrm{Cl}_{2}\right)$. This afforded compound $5 \mathrm{c}$ as a yellow oil $(1.10 \mathrm{~g}, 74 \%) ;{ }^{1} \mathrm{H} \mathrm{NMR}\left(\mathrm{d}_{6}-\mathrm{DMSO}\right) \delta 2.80(2 \mathrm{H}, \mathrm{t}$, $\left.\mathrm{PhCH}_{2}\right), 3.42\left(2 \mathrm{H}, \mathrm{m}, \mathrm{CH}_{2} \mathrm{O}\right), 3.50\left(10 \mathrm{H}, \mathrm{m}, 5 \times \mathrm{CH}_{2} \mathrm{O}\right), 3.60(2 \mathrm{H}, \mathrm{t}$, $\left.\mathrm{PhCH}_{2} \mathrm{CH}_{2} \mathrm{O}\right), 4.60\left(1 \mathrm{H}\right.$, br t, OH), $7.03(2 \mathrm{H}, \mathrm{m}$, ar $\mathrm{H}), 7.30(2 \mathrm{H}, \mathrm{m}$, ar $\mathrm{H}) ;{ }^{13} \mathrm{C}$ NMR ( $\mathrm{d}_{6}$-DMSO) $\delta 34.8\left(\mathrm{PhCH}_{2}\right), 60.2,64.6,69.5,69.7,69.8,71.1$, and $72.3(7$ $\left.\times \mathrm{CH}_{2} \mathrm{O}\right), 118.8,130.4,136.2$, and $137.1(\operatorname{ar} \mathrm{C})$.

\section{2-(4-Azidophenethoxy)-3-methyl-2-oxo-1,3,2-oxazaphospholidine (6a).}

To a solution of $\mathrm{POCl}_{3}(4.14 \mathrm{~g} ; 27.0 \mathrm{mmol})$ in $20 \mathrm{~mL}$ of ether a solution of $\mathrm{NEt}_{3}$ $(3.64 \mathrm{~g} ; 36.0 \mathrm{mmol})$ in $30 \mathrm{~mL}$ of ether was added dropwise while the temperature was kept at $0{ }^{\circ} \mathrm{C}$. When half of the solution had been added the dropwise addition of a solution of 4-azidophenethyl alcohol (2) $(2.94 \mathrm{~g} ; 18.0 \mathrm{mmol})$ in $50 \mathrm{~mL}$ of ether was started. After stirring for $30 \mathrm{~min}$ at $0^{\circ} \mathrm{C}$ and $30 \mathrm{~min}$ at ambient temperature the reaction mixture was filtered (under argon) to remove precipitated triethylammonium chlloride. Toluene was added to the filtrate and the solution was evaporated to dryness. The residue was dissolved in $30 \mathrm{~mL}$ of ether. The solution was cooled to 0 ${ }^{\circ} \mathrm{C}$ and a solution of $\mathrm{NEt}_{3}(1.82 \mathrm{~g} ; 18.0 \mathrm{mmol})$ in $20 \mathrm{~mL}$ of ether was added. To this mixture a solution of 2-(methylamino)ethanol $(1.50 \mathrm{~g} ; 20.0 \mathrm{mmol})$ and $\mathrm{NEt}_{3}(3.64 \mathrm{~g}$; $36.0 \mathrm{mmol}$ ) in $50 \mathrm{~mL}$ of ether was added dropwise. After stirring for $30 \mathrm{~min}$ at $0{ }^{\circ} \mathrm{C}$ and another $30 \mathrm{~min}$ at ambient temperature the reaction mixture was filtered to remove precipitated triethylammonium chloride. Column chromatography $(0 \rightarrow 5 \%$ 
w/v $\mathrm{MeOH}$ in $\mathrm{CH}_{2} \mathrm{Cl}_{2}, \mathrm{R}_{\mathrm{f}}=0.39$ in $\mathrm{CH}_{2} \mathrm{Cl}_{2} / \mathrm{MeOH}$ 95:5 v/v) afforded compound 6a as a yellow oil $(2.72 \mathrm{~g} ; 54 \%) ;{ }^{1} \mathrm{H} \mathrm{NMR}\left(\mathrm{CDCl}_{3}\right) \delta 2.60(3 \mathrm{H}, \mathrm{d}, \mathrm{NMe}), 2.98(2 \mathrm{H}, \mathrm{t}$, $\left.\mathrm{PhCH}_{2}\right), 3.29\left(2 \mathrm{H}, \mathrm{m}, \mathrm{CH}_{2} \mathrm{~N}\right), 4.10-4.35\left(4 \mathrm{H}, \mathrm{m}, 2 \times \mathrm{CH}_{2} \mathrm{OP}\right), 6.98(2 \mathrm{H}, \mathrm{m}$, ar $\mathrm{H}), 7.25\left(2 \mathrm{H}, \mathrm{m}\right.$, ar H); ${ }^{13} \mathrm{C} \mathrm{NMR}\left(\mathrm{CDCl}_{3}\right) \delta 31.1(\mathrm{~d}, \mathrm{NMe}), 36.2\left(\mathrm{~d}, \mathrm{PhCH}_{2}\right), 49.0$ (d, $\mathrm{CH}_{2} \mathrm{~N}$ ), 63.8 (d, $\mathrm{PhCH}_{2} \mathrm{CH}_{2} \mathrm{OP}$ ), 67.7 (d, $\left.\mathrm{POCH}_{2} \mathrm{CH}_{2} \mathrm{~N}\right), 118.9$ (2 ar C), 130.3 $(2 \operatorname{ar~C}), 134.1(\operatorname{ar~C}), 138.3(\operatorname{ar~C}) ;{ }^{31} \mathrm{P}$ NMR $\left(\mathrm{CDCl}_{3}\right) \delta 22.0$.

\section{2-(2-(4-Azidophenethoxy)ethoxy)-3-methyl-2-oxo-1,3,2-oxazaphospholidine} (6b). To a solution of $\mathrm{POCl}_{3}(1.90 \mathrm{~g} ; 12.3 \mathrm{mmol})$ in $6 \mathrm{~mL}$ of ether a solution of $\mathrm{NEt}_{3}(0.83 \mathrm{~g} ; 8.20 \mathrm{mmol})$ in $6 \mathrm{~mL}$ of ether was added dropwise while the temperature was kept at $0{ }^{\circ} \mathrm{C}$. When half of the solution had been added the dropwise addition of a solution of alcohol $5 \mathrm{~b}(0.85 \mathrm{~g} ; 4.1 \mathrm{mmol})$ in $6 \mathrm{~mL}$ of ether was started. After stirring for $30 \mathrm{~min}$ at $0{ }^{\circ} \mathrm{C}$ and $30 \mathrm{~min}$ at ambient temperature the reaction mixture was filtered (under argon) to remove precipitated triethylammonium chloride. Toluene was added to the filtrate and the solution was evaporated to dryness. The residue was dissolved in $6 \mathrm{~mL}$ of ether. The solution was cooled to 0 ${ }^{\circ} \mathrm{C}$ and a solution of $\mathrm{NEt}_{3}(0.42 \mathrm{~g} ; 4.11 \mathrm{mmol})$ in $4 \mathrm{~mL}$ of ether was added. To this mixture a solution of 2-(methylamino)ethanol $(0.37 \mathrm{~g} ; 4.90 \mathrm{mmol})$ and $\mathrm{NEt}_{3}(0.83 \mathrm{~g}$; $8.20 \mathrm{mmol}$ ) in $8 \mathrm{~mL}$ of ether was added dropwise. After stirring for $30 \mathrm{~min}$ at $0^{\circ} \mathrm{C}$ and $30 \mathrm{~min}$ at ambient temperature the reaction mixture was filtered to remove precipitated triethylammonium chloride. Column chromatography $(0 \rightarrow 5 \% \mathrm{v} / \mathrm{v}$ $\mathrm{MeOH}$ in $\mathrm{CH}_{2} \mathrm{Cl}_{2}, \mathrm{R}_{\mathrm{f}}=0.50$ in $\mathrm{CH}_{2} \mathrm{Cl}_{2} / \mathrm{MeOH} 95.5 \mathrm{v} / \mathrm{v}$ ) afforded compound $6 \mathbf{b}$ as a yellow oil $(0.57 \mathrm{~g} ; 44 \%)$; ${ }^{1} \mathrm{H}$ NMR $\left(\mathrm{CDCl}_{3}\right) \delta 2.70(3 \mathrm{H}, \mathrm{d}, \mathrm{NMe}), 2.90(2 \mathrm{H}, \mathrm{t}$, $\left.\mathrm{PhCH}_{2}\right), 3.32\left(2 \mathrm{H}, \mathrm{m}, \mathrm{CH}_{2} \mathrm{~N}\right), 3.70\left(4 \mathrm{H}, \mathrm{m}, 2 \times \mathrm{CH}_{2} \mathrm{OC}\right), 4.11-4.37(4 \mathrm{H}, \mathrm{m}, 2 \times$ $\left.\mathrm{CH}_{2} \mathrm{OP}\right), 6.96(2 \mathrm{H}, \mathrm{m}$, ar $\mathrm{H}), 7.22(2 \mathrm{H}, \mathrm{m}$, ar $\mathrm{H}) ;{ }^{13} \mathrm{C} \mathrm{NMR}\left(\mathrm{CDCl}_{3}\right) \& 31.2(\mathrm{~d}$, NMe), $35.5\left(\mathrm{PhCH}_{2}\right), 49.1\left(\mathrm{~d}, \mathrm{CH}_{2} \mathrm{~N}\right), 63.8,66.5,69.9$, and $71.9\left(4 \times \mathrm{CH}_{2} \mathrm{O}\right)$, $118.8,130.2,135.6$, and 137.9 (ar C); ${ }^{31} \mathrm{P}$ NMR $\left(\mathrm{CDCl}_{3}\right) \delta 22.3$.

\section{2-(2-(2-(2-(4-Axidophenethoxy)ethoxy)ethoxy)ethoxy)-3-methyl-2-0x0-1,3,2-} oxazaphospholidine (6c). To a solution of $\mathrm{POCl}_{3}(1.65 \mathrm{~g} ; 10.8 \mathrm{mmol})$ in $6 \mathrm{~mL}$ of ether a solution of $\mathrm{NEt}_{3}(0.73 \mathrm{~g} ; 7.21 \mathrm{mmol})$ in $6 \mathrm{~mL}$ of ether was added dropwise while the temperature was kept at $0{ }^{\circ} \mathrm{C}$. When half of the solution had been added 
the dropwise addition of a solution of alcohol $5 \mathrm{c}(1.06 \mathrm{~g} ; 3.59 \mathrm{mmol})$ in $6 \mathrm{~mL}$ of ether was started. After stirring for $30 \mathrm{~min}$ at $0{ }^{\circ} \mathrm{C}$ and $30 \mathrm{~min}$ at ambient temperature the reaction mixture was filtered (under argon) to remove precipitated triethylammonium chloride. Toluene was added to the filtrate and the solution was evaporated to dryness. The residue was dissolved in $6 \mathrm{~mL}$ of ether. The solution was cooled to $0{ }^{\circ} \mathrm{C}$ and a solution of $\mathrm{NEt}_{3}(0.36 \mathrm{~g} ; 3.56 \mathrm{mmol})$ in $4 \mathrm{~mL}$ of ether was added. To this mixture a solution of 2-(methylamino)ethanol $(0.33 \mathrm{~g} ; 4.39 \mathrm{mmol}$ ) and $\mathrm{NEt}_{3}(0.73 \mathrm{~g} ; 7.21 \mathrm{mmol})$ in $8 \mathrm{~mL}$ of ether was added dropwise. After stirring for $30 \mathrm{~min}$ at $0{ }^{\circ} \mathrm{C}$ and $30 \mathrm{~min}$ at ambient temperature the reaction mixture was filtered to remove precipitated triethylammonium chloride. Column chromatography $\left(0 \rightarrow 5 \% \mathrm{v} / \mathrm{v} \mathrm{MeOH}\right.$ in $\mathrm{CH}_{2} \mathrm{Cl}_{2}, \mathrm{R}_{\mathrm{f}}=0.50$ in $\left.\mathrm{CH}_{2} \mathrm{Cl}_{2} / \mathrm{MeOH} 95: 5 \mathrm{v} / \mathrm{v}\right)$ afforded compound $6 \mathrm{c}$ as a yellow oil $(0.44 \mathrm{~g} ; 30 \%) ;{ }^{1} \mathrm{H} \mathrm{NMR}\left(\mathrm{CDCl}_{3}\right) \delta 2.70(3 \mathrm{H}$, d, $\mathrm{NMe}), 2.88\left(2 \mathrm{H}, \mathrm{t}, \mathrm{PhCH}_{2}\right), 3.32\left(2 \mathrm{H}, \mathrm{m}, \mathrm{CH}_{2} \mathrm{~N}\right), 3.63\left(12 \mathrm{H}, \mathrm{m}, 6 \times \mathrm{CH}_{2} \mathrm{O}\right)$, 4.12-4.36 (4H, m, $\left.2 \times \mathrm{CH}_{2} \mathrm{OP}\right), 6.95\left(2 \mathrm{H}, \mathrm{m}\right.$, ar H), $7.20(2 \mathrm{H}, \mathrm{m}$, ar $\mathrm{H}) ;{ }^{13} \mathrm{C}$ NMR $\left(\mathrm{CDCl}_{3}\right) \delta 31.2(\mathrm{~d}, \mathrm{NMe}), 35.5\left(\mathrm{PhCH}_{2}\right), 49.1\left(\mathrm{~d}, \mathrm{CH}_{2} \mathrm{~N}\right), 63.8,66.5,69.8,70.2$, $70.3,70.4,70.5$, and $72.1\left(8 \times \mathrm{CH}_{2} \mathrm{O}\right), 118.9,130.2,135.8$, and $137.9($ ar $\mathrm{C}) ;{ }^{31} \mathrm{P}$ $\mathrm{NMR}\left(\mathrm{CDCl}_{3}\right) \delta 22.3$.

4-Axidophenethyl 2-(trimethylammonium)ethyl phosphate (1a). Compound 6 a $(2.72 \mathrm{~g} ; 9.60 \mathrm{mmol})$ was dissolved in $30 \mathrm{~mL}$ of acetone/water $6: 1 \mathrm{v} / \mathrm{v}$. The compound was hydrolyzed by adding a small amount of $1 \mathrm{M}$ hydrochloric acid $(0.5$ $\mathrm{mL} ; 0.5 \mathrm{mmol} \mathrm{HCl}$ ). After $15 \mathrm{~min}$ the reaction mixture was evaporated to dryness and coevaporated with acetonitrile. The residue was dissolved in $30 \mathrm{~mL}$ of methanol. Methylation of the compound was performed by adding $40 \%$ w/w aqueous $\mathrm{NaOH}$ (1.44 mL; $20.6 \mathrm{mmol} \mathrm{NaOH})$ and dimethyl sulfate $(1.95 \mathrm{~mL} ; 2.60 \mathrm{~g} ; 20.6 \mathrm{mmol})$. After stirring for $1 \mathrm{~h} 30 \%$ ammonia $\left(3.0 \mathrm{~mL} ; 48 \mathrm{mmol} \mathrm{NH}_{3}\right)$ was added to decompose excess dimethyl sulfate. After $30 \mathrm{~min}$ the reaction mixture was evaporated to dryness and coevaporated with acetonitrile. Purification with column chromatography $\left(0 \rightarrow 10 \% \mathrm{H}_{2} \mathrm{O}\right.$ in methanol, $\mathrm{R}_{\mathrm{f}}=0.18$ in $\mathrm{MeOH} / \mathrm{H}_{2} \mathrm{O} 9: 1 \mathrm{v} / \mathrm{v}$ ) yielded compound $1 \mathrm{la}$ as a sticky yellow solid $(2.46 \mathrm{~g} ; 78 \%) ;{ }^{1} \mathrm{H}$ NMR (d $\left.-\mathrm{DMSO}\right) \delta$ $2.80\left(2 \mathrm{H}, \mathrm{t}, \mathrm{PhCH}_{2}\right), 3.12\left(9 \mathrm{H}, \mathrm{s}, \mathrm{NMe}_{3}\right), 3.49\left(2 \mathrm{H}\right.$, br t, $\left.\mathrm{CH}_{2}{ }^{14} \mathrm{~N}\right), 3.81(2 \mathrm{H}, \mathrm{q}$, $\left.\mathrm{PhCH}_{2} \mathrm{CH}_{2} \mathrm{OP}\right), 3.95\left(2 \mathrm{H}\right.$, br m, $\left.\mathrm{POCH}_{2} \mathrm{CH}_{2}{ }^{14} \mathrm{~N}\right), 7.02(2 \mathrm{H}, \mathrm{m}$, ar $\mathrm{H}), 7.28(2 \mathrm{H}$, $\mathrm{m}$, ar H); ${ }^{13} \mathrm{C} \mathrm{NMR}\left(\mathrm{d}_{6}-\mathrm{DMSO}\right) 836.1\left(\mathrm{~d}, \mathrm{PhCH}_{2}\right), 53.1$ (3 lines, $\left.{ }^{14} \mathrm{NMe}_{3}\right), 58.1(\mathrm{~d}$, 
$\mathrm{POCH}_{2} \mathrm{CH}_{2} \mathrm{~N}$ ), 64.6 (d, $\mathrm{PhCH}_{2} \mathrm{CH}_{2} \mathrm{OP}$ ), 65.4 (5 lines, $\mathrm{CH}_{2}{ }^{14} \mathrm{~N}$ ), 118.4 (2 ar C), 130.5 (2 ar C), $136.4(1 \operatorname{ar~C}), 137.0\left(1\right.$ ar C); ${ }^{31} \mathrm{P}$ NMR (d. DMSO) 80.20 .

\section{2-(4-Azidophenethoxy)ethyl 2-(trimethylammonium)ethyl phosphate (1b).} Compound $6 \mathrm{~b}(0.55 \mathrm{~g} ; 1.69 \mathrm{mmol})$ was dissolved in $10 \mathrm{~mL}$ of acetone/water $6: 1$ $\mathrm{v} / \mathrm{v}$. The compound was hydrolyzed by adding a small amount of $1 \mathrm{M}$ hydrochloric acid $(0.1 \mathrm{~mL} ; 0.1 \mathrm{mmol} \mathrm{HCl})$. After $15 \mathrm{~min}$ the reaction mixture was evaporated to dryness and coevaporated with acetonitrile. The residue was dissolved in $5 \mathrm{~mL}$ of methanol. Methylation of the compound was performed by adding $40 \% \mathrm{w} / \mathrm{w}$ aqueous $\mathrm{NaOH}(0.26 \mathrm{~mL} ; 3.72 \mathrm{mmol} \mathrm{NaOH})$ and dimethyl sulfate $(0.36 \mathrm{~mL} ; 0.46 \mathrm{~g} ; 3.72$ mmol). After stirring for $1 \mathrm{~h} 30 \% \mathrm{w} / \mathrm{w}$ aqueous ammonia $\left(0.5 \mathrm{~mL} ; 8 \mathrm{mmol} \mathrm{\textrm {NH } _ { 3 }}\right)$ was added to decompose excess dimethyl sulfate. After 30 min the reaction mixture was evaporated to dryness and coevaporated with acetonitrile. Purification with column chromatography $\left(0 \rightarrow 10 \% \mathrm{H}_{2} \mathrm{O}\right.$ in methanol, $\mathrm{R}_{\mathrm{f}}=0.20$ in $\mathrm{MeOH} / \mathrm{H}_{2} \mathrm{O} 9: 1$ $\mathrm{v} / \mathrm{v})$ yielded compound $1 \mathrm{~b}$ as a sticky yellow solid $(0.47 \mathrm{~g} ; 75 \%) ;{ }^{1} \mathrm{H}$ NMR $\left(\mathrm{d}_{6}-\right.$ DMSO) $\delta 2.80\left(2 \mathrm{H}, \mathrm{t}, \mathrm{PhCH}_{2}\right), 3.13\left(9 \mathrm{H}, \mathrm{s}, \mathrm{NMe}_{3}\right), 3.50\left(4 \mathrm{H}, \mathrm{m}, \mathrm{CH}_{2} \mathrm{~N}\right.$ and $\left.\mathrm{OCH}_{2} \mathrm{CH}_{2} \mathrm{OP}\right), 3.60\left(2 \mathrm{H}, \mathrm{t}, \mathrm{PhCH}_{2} \mathrm{CH}_{2} \mathrm{O}\right), 3.72\left(2 \mathrm{H}, \mathrm{q}, \mathrm{OCH}_{2} \mathrm{CH}_{2} \mathrm{OP}\right), 4.02(2 \mathrm{H}$, br m, POCH$\left.{ }_{2} \mathrm{CH}_{2}{ }^{14} \mathrm{~N}\right), 7.03(2 \mathrm{H}, \mathrm{m}$, ar $\mathrm{H}), 7.30(2 \mathrm{H}, \mathrm{m}$, ar $\mathrm{H}) ;{ }^{13} \mathrm{C} \mathrm{NMR}\left(\mathrm{d}_{6^{-}}\right.$ DMSO) $\delta 34.9\left(\mathrm{PhCH}_{2}\right), 53.1\left(\mathrm{NMe}_{3}\right), 58.2\left(\mathrm{~d}, \mathrm{POCH}_{2} \mathrm{CH}_{2} \mathrm{~N}\right), 63.3\left(\mathrm{CH}_{2} \mathrm{O}\right), 65.5$ (m, $\left.\mathrm{CH}_{2}{ }^{14} \mathrm{~N}\right), 70.3$, and $71.1\left(2 \times \mathrm{CH}_{2} \mathrm{O}\right), 118.9,130.5,136.2$, and 137.1 (ar C); ${ }^{3 i} \mathrm{P}$ NMR (d $\mathrm{d}_{6}$-DMSO) 80.17 .

\section{2-(2-(2-(4-Azidophenethoxy)ethoxy)ethoxy)ethyl} 2-(trimethylammonium) ethyl phosphate (1c). Compound $6 \mathrm{c}(0.42 \mathrm{~g} ; 1.01 \mathrm{mmol})$ was dissolved in $10 \mathrm{~mL}$ of acetone/water $6: 1 \mathrm{v} / \mathrm{v}$. The compound was hydrolyzed by adding a small amount of $1 \mathrm{M}$ hydrochloric acid $(0.1 \mathrm{~mL} ; 0.1 \mathrm{mmol} \mathrm{HCl})$. After $15 \mathrm{~min}$ the reaction mixture was evaporated to dryness and coevaporated with acetonitrile. The residue was dissolved in $5 \mathrm{~mL}$ of methanol. Methylation of the compound was performed by adding $40 \%$ w/w aqueous $\mathrm{NaOH}(0.16 \mathrm{~mL} ; 2.22 \mathrm{mmol} \mathrm{NaOH})$ and dimethyl sulfate $(0.21 \mathrm{~mL} ; 0.28 \mathrm{~g} ; 2.22 \mathrm{mmol})$. After stirring for $1 \mathrm{~h} 30 \% \mathrm{w} / \mathrm{w}$ aqueous ammonia $\left(0.3 \mathrm{~mL} ; 5 \mathrm{mmol} \mathrm{NH}_{3}\right)$ was added to decompose excess dimethyl sulfate. After 30 min the reaction mixture was evaporated to dryness and coevaporated with acetonitrile. Purification with column chromatography $\left(0 \rightarrow 10 \% \mathrm{H}_{2} \mathrm{O}\right.$ in methanol, 
$\mathrm{R}_{\mathrm{f}}=0.20$ in $\mathrm{MeOH} / \mathrm{H}_{2} \mathrm{O} 9.1 \mathrm{v} / \mathrm{v}$ ) yielded compound $1 \mathrm{c}$ as a sticky yellow solid $(0.39 \mathrm{~g} ; 83 \%) ;{ }^{1} \mathrm{H}$ NMR (d $\left.-\mathrm{DMSO}\right) \delta 2.81\left(2 \mathrm{H}, \mathrm{t}, \mathrm{PhCH}_{2}\right), 3.13\left(9 \mathrm{H}, \mathrm{s}, \mathrm{NMe}_{3}\right)$, $3.50\left(12 \mathrm{H}, \mathrm{m}, 6 \times \mathrm{CH}_{2}\right), 3.60\left(2 \mathrm{H}, \mathrm{t}, \mathrm{PhCH}_{2} \mathrm{CH}_{2} \mathrm{O}\right), 3.70\left(2 \mathrm{H}, \mathrm{q}, \mathrm{OCH}_{2} \mathrm{CH}_{2} \mathrm{OP}\right)$, $4.02\left(2 \mathrm{H}\right.$, br m, $\left.\mathrm{POCH}_{2} \mathrm{CH}_{2}{ }^{14} \mathrm{~N}\right), 7.03(2 \mathrm{H}, \mathrm{m}$, ar $\mathrm{H}), 7.30(2 \mathrm{H}, \mathrm{m}$, ar $\mathrm{H}) ;{ }^{13} \mathrm{C}$ NMR $\left(\mathrm{d}_{6}-\mathrm{DMSO}\right) \delta 34.8\left(\mathrm{PhCH}_{2}\right), 53.1\left(\mathrm{NMe}_{3}\right), 58.3\left(\mathrm{~d}, \mathrm{POCH}_{2} \mathrm{CH}_{2} \mathrm{~N}\right), 63.3$ and $64.7\left(2 \times \mathrm{CH}_{2} \mathrm{O}\right), 65.5\left(\mathrm{~m}, \mathrm{CH}_{2}{ }^{14} \mathrm{~N}\right), 69.5,69.7,69.8,70.7$, and $71.1\left(5 \times \mathrm{CH}_{2} \mathrm{O}\right)$, $118.9,130.5,136.2$, and 137.1 (ar C); ${ }^{31} \mathrm{P}$ NMR (d ${ }_{6}$-DMSO) 80.22 .

\section{Results}

The synthetic scheme can be divided in three parts. In the first part building blocks 2 (the azido alcohol) and 3 (the spacer molecule) were prepared (Scheme 1). These compounds were coupled in the second part (Scheme 2). The PC group was introduced in the third part (Scheme 3 ). Target compounds 1 were obtained via the cyclic intermediates 6 .

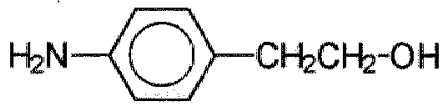

$\left.\mathrm{HO}+\mathrm{CH}_{2} \mathrm{CH}_{2}-\mathrm{O}+\right]_{x}^{-}$

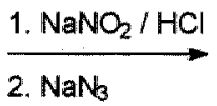

1. $\mathrm{Ph}_{3} \mathrm{CCl}$

2. $\mathrm{Php} / \mathrm{Br}_{2}$

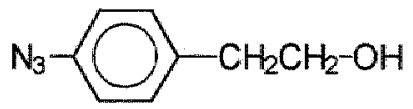

2

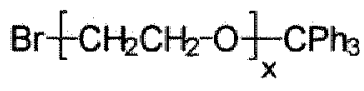

$3 \mathbf{b}=1$
$3 \mathbf{c} x=3$

\section{Scheme 1}

The azido alcohol 2 was prepared from 4-aminophenethyl alcohol via a standard diazotation reaction with sodium nitrite and hydrochloric acid followed by substitution with azide ion, in excellent yield (90\%) (Scheme 1). Two spacer molecules, $\mathbf{3 b}$ and $\mathbf{3 c}$, were synthesized from ethylene glycol and triethylene glycol, respectively. For this purpose one of the hydroxyl groups of the diols was protected 
by reacting it with a small amount of trityl chloride (in pyridine). The yield of this reaction could be increased up to $90 \%$ (based on trityl chloride) by adding trityl chloride in small portions over a period of several $\mathbf{h}$. The monoprotected diols were converted into the corresponding bromides $3 \mathbf{b}$ and $3 \mathbf{c}$ by the $\mathrm{Ph}_{3} \mathrm{PBr}_{2}$ reagent (which was prepared in situ from triphenylphosphine and bromine), in excellent yield (approx. 90\% for both compounds).

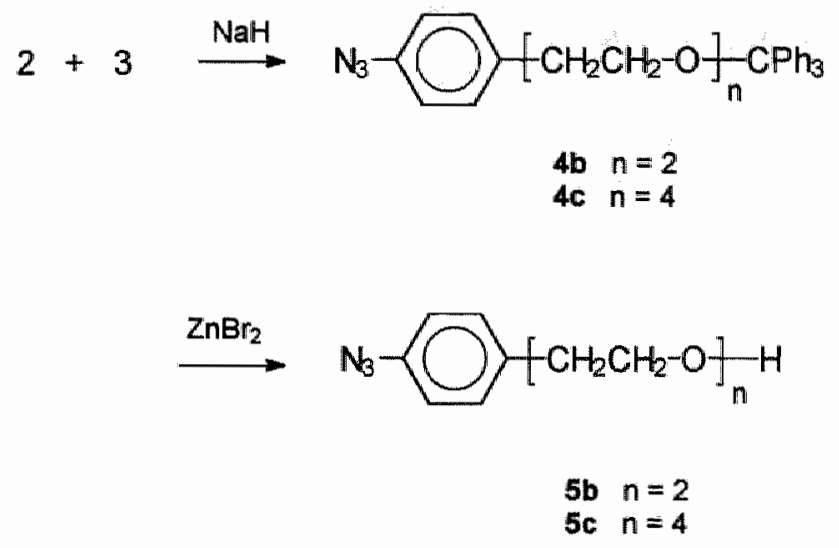

Scheme 2

Coupling of 2 and 3 was performed by a Williamson reaction, using sodium hydride to convert the alcohol into alkoxide (Scheme 2). The ethers $4 \mathbf{b}$ and $\mathbf{4 c}$ were obtained in moderate yield (67\% and 58\% respectively). Deprotection of the trityl ethers was carried out with a solution of zinc bromide in dichloromethane/methanol $8: 2 \mathrm{v} / \mathrm{v} .{ }^{20}$ This resulted in the formation of the azido alcohols $\mathbf{5 b}$ and $\mathbf{5 c}$ in high yield (79\% and $74 \%$ respectively).

The PC group was introduced according to a procedure first described by Eibl, ${ }^{21}$ and later also applied by Macdonald ${ }^{22}$ (Scheme 3). Phosphorus oxychloride was reacted with the azido alcohols 5 and $\mathbf{2}$ in the presence of triethylamine yielding the intermediate dichlorophosphate esters. To prevent substitution of more than one chlorine atom compounds 5 and $\mathbf{2}$ were added slowly to an excess of phosphorus oxychloride, while keeping the temperature at approximately $0^{\circ} \mathrm{C}$. After removing precipitated triethylammonium chloride (by filtration) and excess phosphorus oxychloride (by evaporation), the crude product was directly reacted with 
2-(methylamino)ethanol in the presence of triethylamine, affording oxazaphospholidines $6 a-c$ in low to moderate yield $(54 \%, 44 \%$, and $30 \%$ respectively). Specific hydrolysis (using acidic conditions) of the $\mathrm{P}-\mathrm{N}$ bond in cyclic oxazaphospholidines can be accomplished without affecting the $\mathrm{P}-\mathrm{O}$ bond, according to Eibl. ${ }^{21}$ Compounds 6 were readily hydrolyzed by a trace of hydrochloric acid in acetone/water $6: 1 \mathrm{v} / \mathrm{v}$. After evaporation of the solvents the methylamino group of the reaction products was methylated with dimethyl sulfate in a concentrated aqueous sodium hydroxide solution. The crude reaction products were purified by column chromatography using silicagel as the stationary phase and a gradient solution of water $(0$ to $10 \% \mathrm{v} / \mathrm{v})$ in methanol as the mobile phase. This afforded the target compounds $1 \mathrm{a}-\mathrm{c}$ in high yield $(78 \%, 75 \%$, and $83 \%$ respectively).

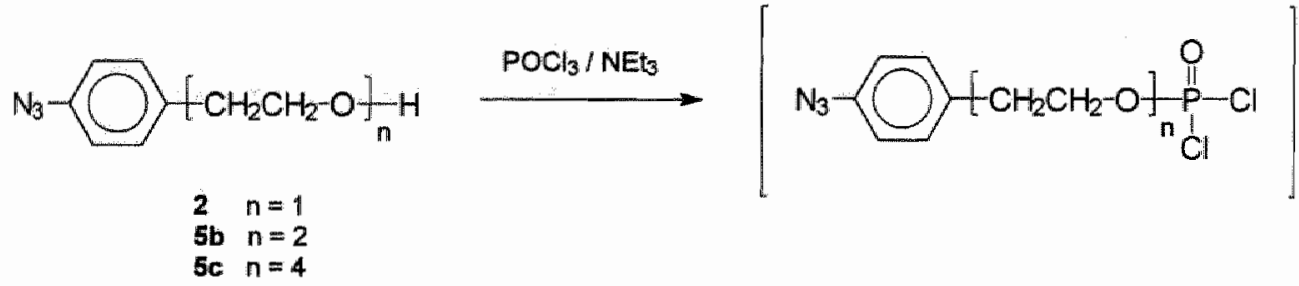

$\mathrm{MeNHCH} \mathrm{CH}_{2} \mathrm{OH}$

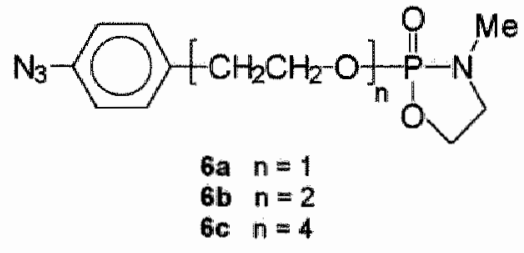

1. $\mathrm{HCl}$

2. $\mathrm{Me}_{2} \mathrm{SO}_{4} / \mathrm{NaOH}$<smiles></smiles>

1a $n=1$

Ib $n=2$

Ic $n=4$

Scheme 3 


\section{Discussion}

The critical step in the synthesis of the aryl azides described in this work is the introduction of the PC group. The approach followed here to introduce it is based on the work of Eibl ${ }^{21}$ and Macdonald. ${ }^{22}$ The yields in this study were lower than expected which could be due to decomposition of the intermediate dichlorophosphate esters during filtration of precipitated triethylammonium chloride that proved to be laborious. Still, this approach has advantages over other methods: the reactions proceed rapidly under mild conditions with no or little formation of by-products.

Another, more laborious, approach to synthesize alkyl phosphorylcholines also uses phosphorus oxychloride to prepare dichlorophosphate esters. ${ }^{23}$ These are then cyclized with ethylene glycol. Treatment with trimethylamine at $75^{\circ} \mathrm{C}$ under pressure (in a sealed tube) for $30 \mathrm{~h}$ gives the product in moderate (35-50\%) overall yield. In a third approach the phosphorus heterocycle is constructed first. ${ }^{24}$ The reaction between phosphorus trichloride and 2-(methylamino)ethanol affords the heterocyclic 2-chloro-3-methyl-1,3,2-oxazaphosphacyclopentane. The chlorine atom of this compound can be substituted with alcohols after which oxidation (with dinitrogen tetroxide) gives 3-methyl-2-oxo-1,3,2-oxazaphospholidines such as compounds 6 that can be hydrolyzed and methylated as described in this report. This approach has also been used in this laboratory (using tert-butylhydroperoxide as the oxidizing reagent) but the method described in the current report was preferred since it does not require the time-consuming synthesis and distillation of the phosphorus heterocycle. ${ }^{25}$

In conclusion, a method was reported for the convenient synthesis of aryl azides with a phosphorylcholine endgroup. The synthetic approach permits the preparation of molecules with a variable-length spacer chain constructed from ethylene glycol units. The compounds described here can be used for the photochemical surface modification of polymeric materials to improve their blood compatibility. 


\section{References}

1. H. Bayley, Photogenerated Reagents in Biochemistry and Molecular Biology, Elsevier, New York, 1983.

2. E.F.V. Scriven (ed.), Azides and Nitrenes, Academic Press, New York, 1984.

3. T. Sugawara and T. Matsuda, "Synthesis of phenylazido-derivatized substances and photochemical surface modification to immobilize functional groups," J. Biomed. Mater. Res., 32, 157-164 (1996).

4. Y.-C. Tseng and K. Park, "Synthesis of photoreactive poly(ethylene glycol) and its application to the prevention of surface-induced platelet activation, ${ }^{\prime} J$. Biomed. Mater. Res., 26, 373-391 (1992).

5. M. Erdtmann, R. Keller, and H. Baumann, "Photochemical immobilization of heparin, dermatan sulphate, dextran sulphate and endothelial cell surface heparan sulphate onto cellulose membranes for the preparation of athrombogenic and antithrombogenic polymers," Biomaterials, 15, 1043-1048 (1994).

6. G.H. Engbers and J. Feijen, "Current techniques to improve the blood compatibility of biomaterial surfaces," Int. J. Antif. Organs, 14, 199-215 (1991).

7. Y. Ikada, "Surface modification of polymers for medical applications," Biomaterials, 15, 725-736 (1994).

8. C.H. Bamford and K.G. Al-Lamee, "Chemical methods for improving the haemocompatibility of synthetic polymers," Clin. Mater., 10, 243-261 (1992).

9. N.A. Peppas and R. Langer, "New challenges in biomaterials," Science, 263, 17151720 (1994).

10. E.F.V. Scriven and $\mathbb{K}$. Turnbull, "Azides: Their preparation and synthetic uses," Chem. Rev., 88, 297-368 (1988).

11. A.P. van der Heiden and L.H. Koole, "Photochemical coupling of aryl azides to poly(ether urethane) surfaces: Studies with a fluorescent model compound," Macromolecules, 29, 7012-7015 (1996).

12. J.M.H. Kuijpens, G.A. Kardaun, A.P. Pijpers, and L.H. Koole, "Immobilization of theophylline on medical-grade polyurethane inhibits surface-induced activation of platelets," J. Am. Chem. Soc., 117, 8691-8697 (1995).

13. Y.B.J. Aldenhoff, A.P. Pijpers, and L.H. Koole, "Synthesis of a new photoreactive derivative of dipyridamole and its use in the manufacture of artificial surfaces with low thrombogenicity," Bioconjugate Chem., 8, 296-303 (1997).

14. A.P. van der Heiden, D. Goebbels, A.P. Pijpers, and L.H. Koole, "A photochemical method for the surface modification of poly(ether urethanes) with phosphorylcholinecontaining compounds to improve hemocompatibility," J. Biomed. Mater. Res., 37, 282-290 (1997).

15. M.D. Lelah and S.L. Cooper, Polyurethanes in Medicine, CRC Press, Boca Raton, Florida, 1986.

16. J.A. Hayward and D. Chapman, "Biomembrane surfaces as models for polymer design: The potential for haemocompatibility, Biomaterials, 5, 135-142 (1984).

17. A.A. Durrani, J.A. Hayward, and D. Chapman, "Biomembranes as models for polymer surfaces. II. The syntheses of reactive species for covalent coupling of phosphorylcholine to polymer surfaces," Biomaterials, 7, 121-125 (1986). 
18. K. Ishihara, S. Tanaka, N. Furukawa, K. Kurita, and N. Nakabayashi, "Improved blood compatibility of segmented polyurethanes by polymeric additives having phospholipid polar groups. I. Molecular design of polymeric additives and their functions," J. Biomed. Mater. Res., 32, 391-399 (1996).

19. A.S. Köhler, P.J. Parks, D.L. Mooradian, G.H.R. Rao, and L.T. Furcht, "Platelet adhesion to novel phospholipid materials: Modified phosphatidylcholine covalently immobilized to silica, polypropylene, and PTFE materials," J. Biomed. Mater. Res., 32, 237-242 (1996).

20. V. Kohli, H. Blöcker, and H. Köster, "The triphenylmethyl (trityl) group and its use in nucleotide chemistry," Tetrahedron Lett., 21, 2683-2686 (1980).

21. H. Eibl, "Phospholipid synthesis: Oxazaphospholanes and dioxaphospholanes as intermediates," Proc. Natl. Acad. Sci. USA, 75, 4074-4077 (1978).

22. P.M. Macdonald, J.R. Rydall, S.C. Kuebler, and F.M. Winnik, "Synthesis and characterization of a homologous series of zwitterionic surfactants based on phosphocholine," Langmuir, 7, 2602-2606 (1991).

23. R.L. Magolda and P.R. Johnson, "A new and versatile synthesis of alkyl phosphorylcholines," Tetrahedron Lett., 26, 1167-1170 (1985).

24. C. McGuigan and B. Swords, "Synthesis of phospholipids by phosphoramidite methodology," J. Chem. Soc. Perkin Trans, 1, 783-787 (1990).

25. A.P. van der Heiden, (unpublished results). 


\title{
Photochemical Coupling of Aryl Azides to \\ Poly(ether urethane) Surfaces: Studies with a Fluorescent Model Compound *
}

\begin{abstract}
A fluorescent aryl azide [5-dimethylaminonaphthalene-1-(N-methyl- $\mathrm{N}$-(2-hydroxyethyl))sulfonamide 4-azidobenzoate] (2) was synthesized as a model compound for aryl azides that are used for the photochemical surface modification of poly(ether urethanes) (PEUs). This method of surface modification is being used in this laboratory in the search for artificial surfaces with optimized blood compatibility. As a part of this work, two pivotal questions are now addressed: (i) what is the surface density of coupled molecules that can be reached by this method and (ii) is binding to the surface really covalent? After the photochemical coupling of 2 to a PEU surface the ester bonds of the coupled molecules were selectively hydrolyzed with $0.1 \mathrm{M} \mathrm{NaOMe} / \mathrm{MeOH}$ and the concentration of fluorescent moleculles in solution determined spectrofluorometrically. Since not all of the fluorescent molecules were removed by this procedure an additional experiment was performed (in which the polymer was completely dissolved). It was found that $25 \mathrm{nmol} / \mathrm{cm}^{2}$ had coupled to the outermost polymer layers and $7.7 \mathrm{nmol} / \mathrm{cm}^{2}$ to polymer layers more within the material (unreachable for the $\mathrm{NaOMe} / \mathrm{MeOH}$ reagent). In another experiment a modified $\mathrm{PEU}$ sheet was dissolved in THF after which $\mathrm{MeOH}$ was added to precipitate it again. From the fact that no fluorescence was detected in solution it could be concluded that all of the fluorescent molecules were indeed covalently coupled to the polymer surface.
\end{abstract}

* A.P. van der Heiden and L.H. Koole, Macromolecules, 29, 7012-7015 (1996). 


\section{Introduction}

Biomaterials are designed to perform their function in contact with living tissue. They have found widespread applications in all kinds of medical devices. ${ }^{1}$ They can be made of polymers, ceramics, and metals. For applications such as artificial blood vessels polymeric materials are needed with better blood compatibility. Surface modification of existing polymeric materials can improve the materials' interaction with the biological environment while the mechanical (bulk) properties remain essentially unchanged. ${ }^{2,3}$

Several research groups are using surface modification techniques that are based on the photochemical reactivity of aryl azides. ${ }^{4-7}$ In this laboratory aryl azides have been used that carry a dipyridamole ${ }^{8}$ or theophylline group ${ }^{9}$ (which are both platelet inhibitors). At present, aryl azides are studied that carry a phosphorylcholine group. The rationale for this approach lies in the fact that phosphorylcholine is the polar head group of phosphatidylcholine, the most abundant phospholipid in the outer surface of the membrane bilayer of blood platelets. It was argued that phosphorylcholine could "passivate" an artificial surface in such a way that no platelet activation or contact activation can occur and initiate blood coagulation. ${ }^{10}$

Poly(ether urethanes) (PEUs) are already being used in blood-contacting devices, because of their excellent mechanical properties, but the blood compatibility has to be improved for long-term implants. ${ }^{3,11}$ In this laboratory molecules such as $\mathbf{1}$ have been synthesized that contain a photoactivatable 4-azidobenzoyl group at one end of the molecule and a phosphorylcholine group at the other end. After coupling to a PEU surface the phosphorylcholine group rendered the polymer more blood compatible (see Ch. 4). This report deals with two important questions: (i) do aryl azides such as $\mathbf{1}$ and $\mathbf{2}$ indeed couple covalently with reactive groups at a PEU surface and (ii) what surface density can be reached.

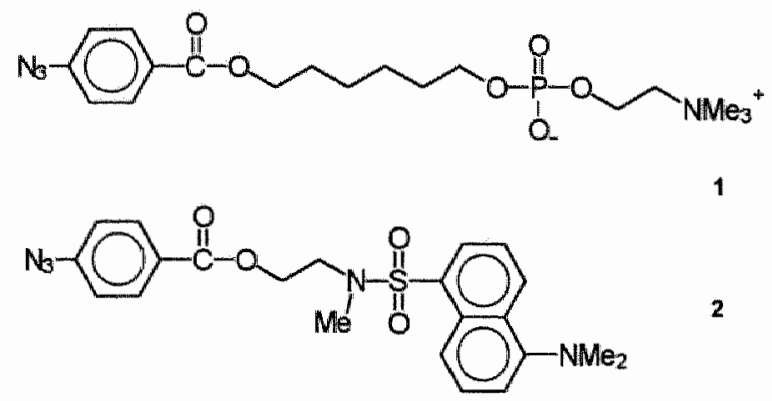


Upon photoactivation an aryl azide splits off nitrogen $\left(\mathrm{N}_{2}\right)$ and a highly reactive intermediate - a singlet nitrene - is formed. The chemistry of nitrenes is complex and not fully understood. ${ }^{12}$ Reaction pathways depend on temperature, the presence of ring substituents, and the availability of nucleophiles. ${ }^{13-16}$ The major pathway in the presence of nucleophiles is shown in Scheme 1. Ring expansion of the nitrene leads to a 1,2-didehydroazepine that can react with various nucleophiles. The electron-withdrawing para-carboxyl substituent increases the reactivity of the 1,2didehydroazepine intermediate as a result of which it can react not only with amines but also with alcohols. ${ }^{15}$ It is likely that even urethane $\mathrm{NH}$ groups are nucleophilic enough to react with the didehydroazepine (vide infra). Didehydroazepine molecules that do not react with the polymer surface will form by-products that can be washed off.

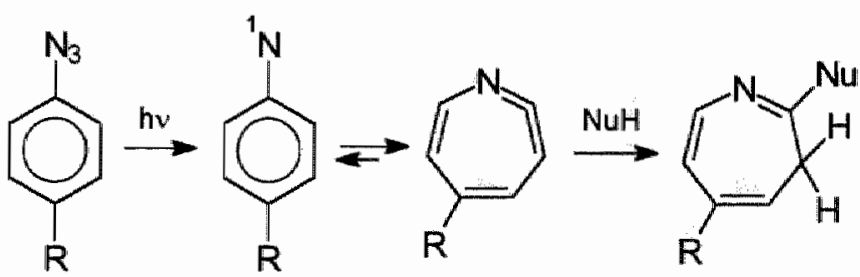

Scheme 1

A method was devised to measure the number of aryl azide molecules that have reacted with a PEU surface. ${ }^{*}$ For this purpose model compound 2 was synthesized (Scheme 2). This compound can be physically adlsorbed to a PEU surface and irradiated with UV light which leads to coupling to the surface. The ester bonds in the coupled molecules can then be hydrolyzed allowing analysis of the resulting solution. The intense fluorescence of the dimethylaminonaphthalenesulfonyl (dansyl) group $^{18}$ is used to determine the surface density of coupled molecules.

${ }^{\dagger}$ Analysis with ESCA (Electron Spectroscopy for Chemical Analysis) can reveal the relative amounts of elements present at the surface (in a layer of about $100 \AA$ thick). For very smooth surfaces (e.g. silicon wafers) also the approximate thickness of a modified surface layer can be deduced from variable angle measurements. ${ }^{17}$ But for the rough surfaces of most polymers ("rough" meaning that the surface contains irregularities larger than the mean free path of inelastic scattering electrons which is about $30 \AA)$ this important information cannot be obtained. 


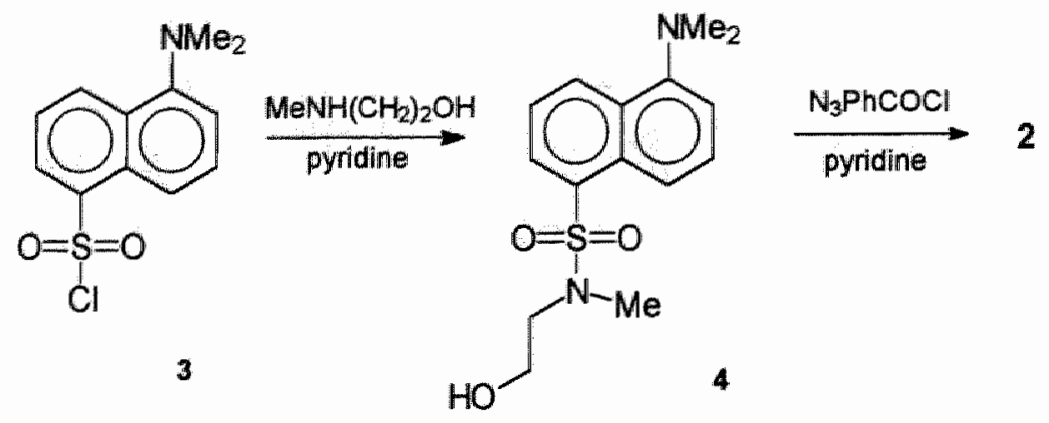

Scheme 2

\section{Experimental}

\section{General}

NMR spectra were recorded on a Varian $400 \mathrm{MHz}$ spectrometer $\left({ }^{1} \mathrm{H}: 399.9\right.$ $\mathrm{MHz} ;{ }^{13} \mathrm{C}$ : $100.6 \mathrm{MHz}$ ). Tetramethylsilane was used as the internal standard for ${ }^{1} \mathrm{H}$ and ${ }^{13} \mathrm{C}$ NMR. Column chromatography was done with Merck silica gel $60(0.063-$ $0.200 \mathrm{~mm}$ ). TLC was performed with Merck silica gel $60 \mathrm{~F}_{254}$ on aluminium sheets. 2-(Methylamino)ethanol was distilled from $\mathrm{CaH}_{2}$ under reduced pressure and stored under nitrogen.

\section{Synthesis}

5-Dimethylaminonaphthalene-1-(N-methyl-N-(2-hydroxyethyl))-sulfonamide (4) A solution of dansyl chloride $(1.89 \mathrm{~g}, 7.00 \mathrm{mmol})$ in $15 \mathrm{ml}$ pyridine was added to a solution of 2 -(methylamino)ethanol $(2.6 \mathrm{~g}, 35 \mathrm{mmol})$ in $15 \mathrm{ml}$ pyridine during $30 \mathrm{~min}$ at $0{ }^{\circ} \mathrm{C}$. After stirring for another $30 \mathrm{~min}$ at $0^{\circ} \mathrm{C}$ and $1 \mathrm{~h}$ at ambient temperature the solution was evaporated. The residue was dissolved in EtOAc and washed with $\mathrm{H}_{2} \mathrm{O}, 0.5 \mathrm{M}$ citric acid, saturated $\mathrm{NaHCO}_{3}$ solution, and brine. The organic layer was dried $\left(\mathrm{MgSO}_{4}\right)$ and evaporated. Silica gel chromatography $\left(\mathrm{CH}_{2} \mathrm{Cl}_{2} / \mathrm{EtOAc} 8: 2 \mathrm{v} / \mathrm{v}, \mathrm{R}_{\mathrm{r}} 0.18\right)$ afforded 4 as a viscous yellow oil $(1.36 \mathrm{~g}, 62 \%)$. ${ }^{H} \mathrm{H}$ NMR $\left(\mathrm{CDCl}_{3}\right) \delta 2.04(1 \mathrm{H}, \mathrm{t}, \mathrm{OH}), 2.89\left(6 \mathrm{H}, \mathrm{s}, \mathrm{NMe}_{2}\right), 2.96(3 \mathrm{H}, \mathrm{s}, \mathrm{NMe})$, $3.35\left(2 \mathrm{H}, \mathrm{t}, \mathrm{CH}_{2} \mathrm{~N}\right), 3.77\left(2 \mathrm{H}, \mathrm{q}, \mathrm{CH}_{2} \mathrm{O}\right), 7.18,7.56(2 \mathrm{H}), 8.20,8.35$, and 8.57 (6 $\mathrm{H}$, naphthyl). ${ }^{13} \mathrm{C} \mathrm{NMR}\left(\mathrm{CDCl}_{3}\right) \delta 35.2(\mathrm{NMe}), 45.4\left(\mathrm{NMe}_{2}\right), 51.8\left(\mathrm{CH}_{2} \mathrm{~N}\right), 60.0$ $\left(\mathrm{OCH}_{2}\right), 115.2,119.3,123.1,128.2,130.0,130.1,130.2,130.6,133.7$, and 151.8 (10 C, naphthyl). MS (ED) $\mathrm{m} / \mathrm{z} 308\left(\mathrm{M}^{+}\right)$. 


\section{5-Dimethylaminonaphthalene-1-(N-methyl- $\mathbf{N}$-(2-hydroxyethyl))-sulfonamide} 4-azidobenzoate (2) 4-Azidobenzoic acid was prepared from 4-aminobenzoic acid by a standard diazotation reaction with $\mathrm{NaNO}_{2}$ (1 equiv) in dilute hydrochloric acid. The resulting diazonium salt was converted into the azide by reaction with $\mathrm{NaN}_{3}$ (1.1 equiv) (yield: $83 \% ; \mathrm{mp} 183-185^{\circ} \mathrm{C}$ (dec.), lit. ${ }^{16,19}: \mathrm{mp} 185^{\circ} \mathrm{C}$ ). The acid was converted into 4-azidobenzoyl chloride by refluxing with $\mathrm{SOCl}_{2}$ in THF followed by crystallization from $\mathrm{n}$-hexane (yield: $81 \% ; \mathrm{mp} 54-56^{\circ} \mathrm{C}$, lit. ${ }^{20}: \mathrm{mp} 57-58^{\circ} \mathrm{C}$ ). To a solution of $4(0.72 \mathrm{~g}, 2.33 \mathrm{mmol})$ in $10 \mathrm{ml}$ pyridine 4-azidobenzoyl chloride $(0.51 \mathrm{~g}$, 2.8 mmol) was added. After $14 \mathrm{~h}$ the solution was evaporated and the residue dissolved in EtOAc. This solution was washed with $0.5 \mathrm{M}$ citric acid, saturated $\mathrm{NaHCO}_{3}$, and brine. The organic layer was dried $\left(\mathrm{MgSO}_{4}\right)$ and evaporated. Silica gel chromatography $\left(\mathrm{CH}_{2} \mathrm{Cl}_{2} /\right.$ EtOAc $\left.97: 3 \mathrm{v} / \mathrm{v}, \mathrm{R}_{\mathrm{f}} 0.28\right)$ provided 2 as a viscous yellow oil $(0.86 \mathrm{~g}, 81 \%) .{ }^{1} \mathrm{H}$ NMR $\left(\mathrm{CDCl}_{3}\right) \delta 2.88\left(6 \mathrm{H}, \mathrm{s}, \mathrm{NMe}_{2}\right), 2.97(3 \mathrm{H}, \mathrm{s}$, $\mathrm{NMe}), 3.65\left(2 \mathrm{H}, \mathrm{t}, \mathrm{CH}_{2} \mathrm{~N}\right), 4.45\left(2 \mathrm{H}, \mathrm{t}, \mathrm{OCH}_{2}\right), 7.02(2 \mathrm{H}, \mathrm{d}, \mathrm{Ph}), 7.92(2 \mathrm{H}, \mathrm{d}$, $\mathrm{Ph}), 7.13,7.48(2 \mathrm{H}), 8.20,8.28$, and $8.52\left(6 \mathrm{H}\right.$, naphthyl). ${ }^{13} \mathrm{C} \mathrm{NMR}\left(\mathrm{CDCl}_{3}\right) \delta$ $35.0(\mathrm{NMe}), 45.4\left(\mathrm{NMe}_{2}\right), 48.4\left(\mathrm{CH}_{2} \mathrm{~N}\right), 62.0\left(\mathrm{OCH}_{2}\right), 115.1,119.3,123.0,128.1$, $129.9,130.0,130.1,130.6,133.9$, and 151.7 (10 C, naphthyl), 118.8 (2 C), 126.1, $131.5(2 \mathrm{C})$, and $144.9(6 \mathrm{C}, \mathrm{Ph}), 165.4(\mathrm{COO})$. MS (EI) $\mathrm{m} / \mathrm{z} 453\left(\mathrm{M}^{+}\right)$. Anal. Calcd for $\mathrm{C}_{22} \mathrm{H}_{23} \mathrm{~N}_{5} \mathrm{O}_{4} \mathrm{~S}: \mathrm{C}, 58.27 ; \mathrm{H}, 5.11 ; \mathrm{N}, 15.44$. Found: $\mathrm{C}, 57.99 ; \mathrm{H}, 5.24 ; \mathrm{N}$, 15.11 .

\section{Photochemical Surface Modification}

A piece $(6 \times 2 \mathrm{~cm})$ of poly(ether urethane) foil (Pellethane $2363-55 \mathrm{D}$, Dow Chemical Inc., thickness $0.13 \mathrm{~mm}$ ) was ultrasonically cleaned with isopropanol, water, and ethanol ( 2 minutes in each solvent) and dried in vacuo. A $5 \mathrm{mM}$ solution of azide $\mathbf{2}$ in isopropanol was sprayed onto the surface ten times, drying with hot air in between. It is estimated that about $0.5 \mathrm{ml}$ of the solution was deposited on the surface. This corresponds with $2.5 \mu \mathrm{mol}$ on $5.6 \mathrm{~cm}^{2}$ of polymer surface or 450 $\mathrm{nmol} / \mathrm{cm}^{2}\left(0.2 \mathrm{mg} / \mathrm{cm}^{2}\right.$; an obvious excess). UV irradiation was performed at a distance of $40 \mathrm{~cm}$ for 20 minutes with a medium-pressure metal halide lamp emitting radiation mainly between 300 and $400 \mathrm{~nm}$. The foil was washed and dried as before (the efficiency of the washing steps could easily be verified by observing the solvents under UV light, $365 \mathrm{~nm}$ ). The surfaces now showed a yellow color (green fluorescent when viewed under UV) but were still transparent. 


\section{Fluorescence Measurements}

A piece of the modified PEU surface $\left(2.8 \times 2.0=5.6 \mathrm{~cm}^{2}\right)$ was treated with $2.5 \mathrm{ml} 0.1 \mathrm{M} \mathrm{NaOMe} / \mathrm{MeOH}(14 \mathrm{~h})$ in order to hydrolyze the ester bonds of the coupled fluorescent molecules. The supernatant liquid was isolated and diluted to $10.9 \mathrm{ml}$ (an arbitrary value, calculated from the weight measured) and the fluorescence intensity determined with a SLM/Aminco SPF-500C spectrofluorometer. The excitation wavelength was set at $340 \mathrm{~nm}$ and emission was measured at $530 \mathrm{~nm}$. This was compared to a reference solution of 4 in $\mathrm{MeOH}$ of about the same concentration $\left(5.0 \times 10^{-6} \mathrm{M}\right)$. At these low concentrations there is a linear relationship between the fluorescence intensity and the concentration. From this the concentration in the sample was determined $\left(1.3 \times 10^{-5} \mathrm{M}\right)$. It follows that $25 \mathrm{nmol} / \mathrm{cm}^{2}$ had been present at the PEU surface.

\section{Results and Discussion}

Dansyl chloride 3 was converted into the dansyl alcohol 4 by reacting it with an excess of 2-(methylamino)ethanol in pyridine (62\% yield). 4-Azidobenzoyl chloride was obtained in two steps (67\% overall yield) from 4-aminobenzoic acid by standard reactions. Coupling of 4 with 4 -azidobenzoyl chloride in pyridine yielded (81\%) azide 2.

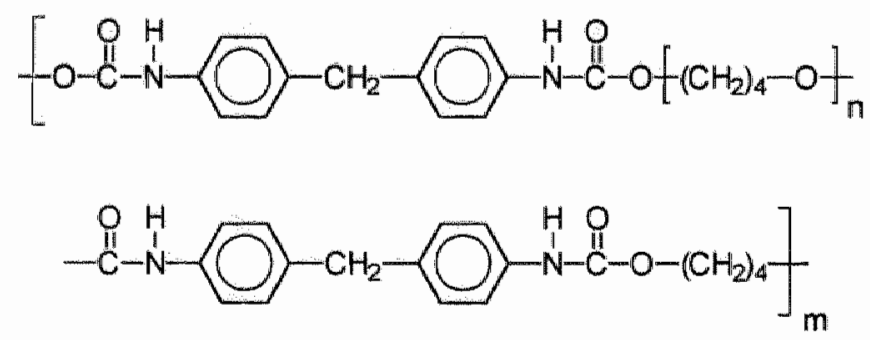

Figure 1. Structural formula of Pellethane 2363-55D. It is made of methylene-4,4'diphenyldiisocyanate, polytetramethylene oxide, and 1,4-butanediol, although its exact composition is proprietary. ${ }^{11}$

A $5 \mathrm{mM}$ solution of 2 in isopropanol (in which PEU hardly swells) was sprayed onto a PEU (Pellethane, Fig. 1) surface followed by drying. The polymer sheet with the adsorbed aryl azide was irradiated with UV-light $(300-400 \mathrm{~nm})$ resulting in 
coupling of 2 with the polymer surface. After extensive washing the polymer sheet was viewed under UV light $(365 \mathrm{~nm})$. Judging from the (green) fluorescence distribution the material was homogeneously coated. A piece of the polymer was dissolved in THF after which $\mathrm{MeOH}$ was added to precipitate it again. The precipitate showed fluorescence while the solution did not (Fig. 2). It follows that the dansyl derivative $\mathbf{2}$ is indeed covalently bound to the PEU surface. The nature of the chemical bond is uncertain. Probably, the urethane NH groups have reacted with the electrophilic didehydroazepine molecules (it is known that urethane NH groups can react with the electrophilic reagents $\mathrm{NaH} /$ alkyl iodide and alkyl diisocyanates ${ }^{3}$ ). Alternatively, $\mathrm{NH}$ or $\mathrm{CH}$ insertion of the singlet (or triplet) nitrene intermediate may have occurred (while insertion reactions of aryl azides in solution are rare, when immobilized on a surface the insertion efficiency might be higher) ${ }^{21}$ No indication was found for the formation of insoluble high molecular weight polyazepines (often called "tar"), ${ }^{22}$ since all by-products could easily be washed off (and were soluble) leaving a transparent polymer sheet.

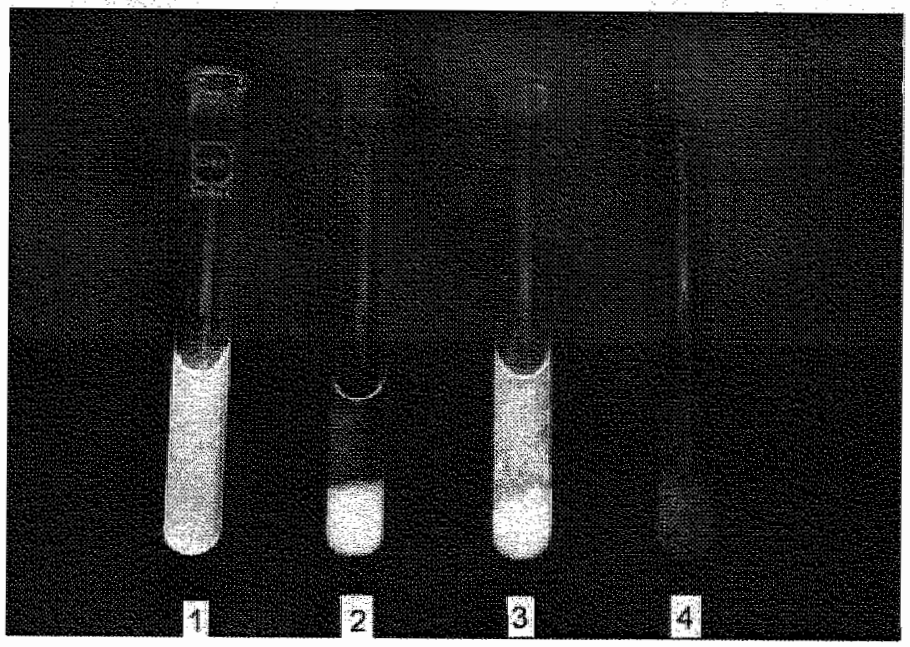

Figure 2. Glass test tubes viewed under UV light $(365 \mathrm{~nm})$. Tube 1 contains a solution of PEU modified with 2, in THF. In tube 2, MeOH was added to a part of this solution, resulting in precipitation of the modified polymer. Because no fluorescence is detected in solution (only the precipitate fluoresces) it must be concluded that all of the fluorescent molecules are covalently bound to the polymer. In tube 3,0.1 $\mathrm{M} \mathrm{NaOMe} / \mathrm{MeOH}$ was added instead of $\mathrm{MeOH}$ resulting in hydrolysis of the ester bonds of coupled molecules 2 , so that the solution shows fluorescence again (not all of the coupled molecules were hydrolyzed in this experiment; see text). Tube 4 is a control: (untreated) PEU precipitated from a solution in THF by adding $\mathrm{MeOH}$. 
To determine the surface density of coupled molecules a piece of the modified polymer was treated with $0.1 \mathrm{M} \mathrm{NaOMe} / \mathrm{MeOH}(14 \mathrm{~h})$ in order to hydrolyze the ester bonds. Note that the urethane groups of the polymer are resistant to this treatment (in solution, urethanes (carbamates) have low reactivity towards $\mathrm{NaOMe} / \mathrm{MeOH}$ at ambient temperanure ${ }^{25}$ ). The concentration of dansyl derivative 4 in solution was determined spectrofluorometrically. It was calculated that $25 \mathrm{nmol} / \mathrm{cm}^{2}\left(7.9 \mu \mathrm{g} / \mathrm{cm}^{2}\right)$ had been present on the polymer surface.

Because the polymer sheet still showed some fluorescence (which was not affected by fresh $\mathrm{NaOMe} / \mathrm{MeOH}$ solution) the material was completely dissolved in THF and $0.1 \mathrm{M} \mathrm{NaOMe} / \mathrm{MeOH}$ was added in order to hydrolyze the ester bonds. The amount of added solution (ca. $20 \% \mathrm{v} / \mathrm{v}$ ) was such that no polymer precipitated. After 14 hours excess $\mathrm{MeOH}$ was added to precipitate the polymer. After centrifugation the solution was isolated (the precipitate showed no fluorescence) and evaporated to dryness. The residue was dissolved in $\mathrm{MeOH}$ and the concentration of dansyl derivative 4 was determined spectrofluorometrically. It was calculated that $7.7 \mathrm{nmol} / \mathrm{cm}^{2}\left(2.3 \mu \mathrm{g} / \mathrm{cm}^{2}\right)$ had been present in the polymer sheet, unreachable for $\mathrm{NaOMe} / \mathrm{MeOH}$. Hence, in total $32.7 \mathrm{nmol} / \mathrm{cm}^{2}\left(10.2 \mu \mathrm{g} / \mathrm{cm}^{2}\right.$, or $2.0 \times 10^{16}$ molecules $/ \mathrm{cm}^{2}$ ) of 2 had coupled to the PEU surface, of which $25 \mathrm{nmol} / \mathrm{cm}^{2}$ to the outermost polymer layers (hydrolyzable by $\mathrm{NaOMe} / \mathrm{MeOH}$ ) and $7.7 \mathrm{nmol} / \mathrm{cm}^{2}$ to polymer layers more within the material (not directly hydrolyzable by $\mathrm{NaOMe} / \mathrm{MeOH}$ ). Note that the surface of a polymer could be defined as that part which is accessible to reagents that are soluble in a non-swelling solvent but insoluble in the polymer. ${ }^{26}$

The surface density found $\left(25 \mathrm{nmol} / \mathrm{cm}^{2}\right)$ is comparable to what was found in an earlier report for the coupling of an aryl azide carrying a dipyridamole group to a PEU surface ( $15 \mathrm{nmol} / \mathrm{cm}^{2}$, measured by UV absorption). ${ }^{8}$ In a determination (by a fluorescence assay) of the surface density of carboxylic groups on polyethylene a value of approximately $3.3 \mathrm{nmol} / \mathrm{cm}^{2}$ was found ${ }^{26}$ In all of these cases the surface densities of functional groups are higher than the surface density of a compressed

\footnotetext{
¥ MeOH does not cause appreciable swelling of the PEU. Furthermore, since NaOMe is a salt it is not expected to penetrate deeper than a few polymer layers into the hydrophobic PEU; in any case, hydrolysis will be much slower for the deeper layers than for the layers close to the surface. ${ }^{23}$ For a discussion of the hydrolysis of ester groups at a polyethylene surface with various alkoxides, see Ref. 24.
} 
oriented stearic acid monolayer $\left(0.8 \mathrm{nmol} / \mathrm{cm}^{2}\right),{ }^{27}$ or a phospholipid layer adsorbed and polymerized on a polyethylene surface $\left(0.3 \mathrm{nmol} / \mathrm{cm}^{2}\right) .{ }^{28}$ There can be two reasons for this. First, the true surface area of the polymers is much higher than the geometric surface area because of the surface roughness. Second, the surface modification schemes in this and the cited investigations undoubtedly result in the modification of a (unknown) number of polymer layers close to the surface.

\section{Conclusions}

Evidence was provided that the photochemical reaction of an aryl azide (containing a carboxyl group para to the azido group) with a poly(ether urethane) surface results in covalently coupled molecules. Furthermore, it appears that the surface density of coupled molecules can be increased to values of about $25 \mathrm{nmol} / \mathrm{cm}^{2}$. With the described method of selective hydrolysis of a fluorescent model compound it was possible to make a distinction between modified polymer layers closest to the surface and layers more deeply buried in the polymer. These results contribute to the validation of photochemical surface modification techniques based on the use of aryl azides. This surface modification method will be applied in this laboratory to modify polymeric surfaces with the aim of improving their blood compatibility in vitro and in vivo.

\section{References}

1. N.A. Peppas and R. Langer, "New challenges in biomaterials," Science, 263, 17151720 (1994).

2. Y. Ikada, "Surface modification of polymers for medical applications," Biomaterials, 15, 725-736 (1994).

3. G.H. Engbers and J. Feijen, "Current techniques to improve the blood compatibility of biomaterial surfaces," Int. J. Artif. Organs, 14, 199-215 (1991).

4. Y.-C. Tseng and K. Park, "Synthesis of photoreactive poly(ethylene glycol) and its application to the prevention of surface-induced platelet activation," $J$. Biomed. Mater. Res., 26, 373-391 (1992).

5. T. Sugawara and T. Matsuda, "Photochemical surface derivatization of a peptide containing Arg-Gly-Asp (RGD)," J. Biomed. Mater. Res., 29, 1047-1052 (1995). 
6. M. Erdtmann, R. Keller, and H. Baumann, "Photochemical immobilization of heparin, dermatan sulphate, dextran sulphate and endothelial cell surface heparan sulphate onto cellulose membranes for the preparation of athrombogenic and antithrombogenic polymers," Biomaterials, 15, 1043-1048 (1994).

7. M. Yan, S.X. Cai, M.N. Wybourne, and J.F.W. Keana "Photochemical functionalization of polymer surfaces and the production of biomoleculecarrying micrometer-scale structures by deep-UV lithography using 4 substifuted perfluorophenyl azides," J. Am. Chem. Soc., 115, 814-816 (1993).

8. Y.B.J. Aldenhoff and L.H. Koole, "Studies on a new strategy for surface modification of polymeric biomaterials, ${ }^{*}$. Biomed. Mater. Res., 29, 917-928 (1995).

9. J.M.H. Kuijpens, G.A. Kardaun, A.P. Pijpers, and L.H. Koole, "Immobilization of theophylline on medical-grade polyurethane inhibits surface-induced activation of platelets," J. Am. Chem. Soc., 117, 8691-97 (1995).

10. D. Chapman, "Biomembranes and new hemocompatible materials," Langmuir, 9, 3945 (1993).

11. M.D. Lellah and S.L. Cooper, Polyurethanes in medicine, CRC Press, Boca Raton, Florida, 1986.

12. E F.V. Scriven (Ed.), Azides and Nitrenes, Academic Press, New York, 1984.

13. Y.-Z. Li, J.P. Kirby, M.W. George, M. Poliakoff, and G.B. Schuster, “1,2Didehydroazepines from the photolysis of substituted aryl azides: Analysis of their chemical and physical properties by time-resolved spectroscopic methods, ${ }^{n} J$. Am. Chem. Soc., 110, 8092-98 (1988).

14. C.G. Younger and R.A. Bell, "Photolysis of 3,4-diamidophenyl azides: Evidence for azirine intermediates," J. Chem. Soc. Chem. Commun., 1359-1361 (1992).

15. P.E. Nielsen and O. Buchardt, "Aryl azides as photoaffinity labels. A photochemical study of some 4-substituted aryl azides," Photochem. Photobiol., 35, 317-323 (1982).

16. C.J. Shields, D.E. Falvey, G.B. Schuster, O. Buchardt, and P. E. Nielsen, ${ }^{\text {tC}}$ Competitive singlet-singlet energy transfer and electron transfer activation of aryl azides: application to photo-cross-linking experiments," J. Org. Chem., 53, 35013507 (1988).

17. J.D. Andrade, in Surface and Interfacial Aspects of Biomedical Polymers. Vol. 1. Surface Chemistry and Physics, J.D. Andrade (Ed.), Plenum Press, New York, 1985, Ch. 5 .

18. A. Mayer and S. Neuenhofer, "Lumineszenzmarker - mehr als nur eine Alternative zu Radioisotopen?," Angew. Chem., 106, 1097-1126 (1994).

19. P. Griess, Z. Chem., $164(1867)$.

20. S.H. Merrill and C.C. Unruh, "Photosensitive azide polymers," J. Appl. Polym. Sci., 7, 273-279 (1963).

21. K.G. Pinney and J.A. Katzenellenbogen, "Synthesis of a tetrafluoro-substituted aryl azide and its protio analogue as photoaffinity labeling reagents for the estrogen receptor," J. Org. Chem., 56, 3125-33 (1991).

22. E.W. Meijer, S. Nijhuis, and F.C.B.M. van Vroonhoven, "Poly-1,2-azepines by the photopolymerization of phenyl azides. Precursors for conducting polymer films," $J$. Am. Chem. Soc., 110, 7209-10 (1988). 
23. S.R. Holmes-Farley and G.M. Whitesides, "Reactivity of carboxylic acid and ester groups in the functionalized interfacial region of "polyethylene carboxylic acid" (PE$\mathrm{CO}_{2} \mathrm{H}$ ) and its derivatives: Differentiation of the functional groups into shallow and deep subsets based on a comparison of contact angle and ATR-IR measurements," Langmuir, 3, 62-76 (1987).

24. D.E. Bergbreiter and G.A. Aguilar, "Solvent effects on ester alcoholysis at functionalized polyethylene surfaces," I. Polym. Sci. Part A: Polym. Chem., 33, 1209-17 (1995).

25. T.W. Greene and P.G.M. Wuts, Protective Groups in Organic Synthesis, 2 nd ed., Wiley-Interscience, New York, 1991, p 442.

26. J.R. Rasmussen, E.R. Stedronsky, and G.M. Whitesides, "Introduction, modification, and characterization of functional groups on the surface of low-density polyethylene film," J. Am. Chem. Soc., 99, 4736-45 (1977).

27. H. Kuhn, D. Mobius, and H. Bucher, in Techniques of Chemistry, A. Weissberger (Ed.), Wiley-Interscience, New York, 1972, Vol. 1 (III-B), p 577.

28. S.L. Regen, P. Kirszensztejn, and A. Singh, "Polymer-supported membranes. A new approach for modifying polymer surfaces," Macromolecules, 16, 335-338 (1983). 


\title{
A photochemical Method for the Surface Modification of Poly(ether urethanes) with Phosphorylcholine-containing Compounds to Improve Hemocompatibility *
}

\begin{abstract}
Phosphorylcholine groups attached to polymer surfaces are known to improve hemocompatibility. A photochemical method is presented here to couple phosphorylcholinem containing aryl azides to poly(ether urethane) surfaces (PEUs). Two aryl azides were synthesized that consist of a photoactivatable 4-azidobenzoyl group, a short spacer chain, and a phosphorylcholine endgroup. The two compounds differ onlly in the type of spacer used: triethyllene glycol for compound 1 and hexanediol for compound 2. These compounds were physically adsorbed to PEU surfaces. Upon UV irradiation reactive intermediates are formed that react with nucleophilic groups on the polymer surface. The modified surfaces showed decreased underwater contact angles, indicating that hydrophillic phosphorylcholine groups are present at the surface. ESCA measurements showed the presence of phosphorus and positively charged nitrogen atoms in the outermost polymer layers (analyzed depth about $50 \AA$ ), which is a strong indication for the presence of phosphorylcholine groups. Hemocompatibility in vitro was tested with thrombin generation assays and platelet adhesion tests. In thrombin generation assays the clotting time of platelet-rich plasma which is in contact with the polymer surface is determined. Clotting times were clearly prolonged for the modified surfaces. Surfaces modified with 2 showed slightly higher clotting times than those modified with 1 . Repeated surface modification with 2 further increased the clotting time. For the tested surfaces an increase in the clotting time corresponded to an increase in the concentration of phosphorylcholine groups at the surface (as measured by ESCA and contact angle). Platelet adhesion studies with scanning electron microscopy demonstrated that fewer platelets (showing less activation) adhered to the modified surfaces than to the unmodified polyurethane.
\end{abstract}

\footnotetext{
"A. P. van der Heiden, D. Goebbels, A. P. Pijpers, and L. H. Koole, J. Biomed. Mater. Res., 37, 282-290 (1997).
} 


\section{Introduction}

In the search for polymeric materials that can be successfully applied as vascular grafts in the human body, many materials have been developed, but only a few have shown satisfactory results in vivo. Thrombus formation at the bloodbiomaterial interface is almost inevitable for long-term implants and can lead to occlusion of the artificial blood vessel or to embolic complications. ${ }^{1}$ Patients with implanted vascular grafts require lifelong administration of anticoagulants such as heparin, causing bleeding disorders in some cases. It is important to realize that a biomaterial's surface essentially controls the interaction with the biological environment while the mechanical properties are determined primarily by its bulk. So, optimization of the surface properties of a material that already has the desired mechanical bulk properties could be a fast and reliable way to develop a new biomaterial with improved blood compatibility.

In this report a method is described for the surface modification of medicalgrade poly(ether urethanes) (PEUs). This class of polymers shows excellent mechanical properties (toughness, durability, and resistance to flex-fatigue) and relatively good blood compatibility, compared to other polymers. ${ }^{1}$ This fairly good blood compatibility is sometimes attributed to the microphase separation of "hard" (rigid methylene diphenyl diurethane) and "soft" (flexible polyether) segments in the polymer chains. ${ }^{2}$ The specific interaction with plasma proteins of these segmented PEUs could be the reason for this behavior. Surface modification of PEUs that increases the hydrophilicity in general improves the blood compatibility due to diminished protein adsorption. Polyethylene glycol groups are often coupled to a PEU surface for this purpose. ${ }^{3}$ Another approach is to couple anticoagulants (as heparin ${ }^{3}$ ) or antiplatelet agents (as dipyridamole ${ }^{4}$ or theophylline ${ }^{5}$ ) to the surface. The approach that is described in the current report is based on the theory that an artificial surface that is covered with certain phospholipids would resemble the outer lipid surface of red blood cells and blood platelets, a surface that can be considered to be perfectly blood compatible. ${ }^{6}$

Several kinds of phospholipids are present in the plasma membrane of red blood cells and blood platelets and they are asymmetrically distributed across the phospholipid bilayer. The phospholipids with an electrically neutral phosphorylcholine headgroup (phosphatidylcholine and sphingomyelin) are 
predominant in the outer membrane leaflet, while the negatively charged phosphatidylserine is found almost exclusively in the inner membrane leaflet. ${ }^{7}$ Upon vascular injury platelets become activated by collagen and thrombin, exposing their cytoplasm to the outside and releasing several compounds that accelerate blood clotting. Also, the asymmetric distribution of phospholipids in the bilayer is lost by the so-called flip-flop mechanism, ${ }^{8}$ causing phosphatidylserine to move from the inner membrane leaflet to the outer, which results in the formation of a procoagulant surface. It was proposed that it is the phosphorylcholine headgroup that is essential for blood compatibility, ${ }^{6}$ and a number of materials have been developed with phosphorylcholine groups attached to the surface. ${ }^{9,10}$ Apart from mimicking (to some degree) the outer lipid surface of blood cells, phosphorylcholine has some other properties that can explain its blood compatibility: it is a very polar, zwitterionic molecule that can bind a large amount of water. ${ }^{11}$ As stated before, increasing the hydrophilicity of PEU surfaces generally improves blood compatibility; and an adsorbed layer of water could effectively shield the surface of the polymer from the flowing blood.

Here a method is presented for coupling phosphorylcholine groups to a PEU surface through a photochemical reaction. For this purpose, two aryl azides (1 and 2) were synthesized that carry a phosphorylcholine endgroup. The compounds differ only in the type of spacer present between the azidophenyl and the phosphorylcholine group. The advantage of this photochemical coupling method over the more classic chemical coupling schemes lies in its relative ease: only a short irradiation with UV light turns the normally stable aryl azide molecules into very reactive compounds that can react with (weakly) nucleophilic groups on a polymer surface. PEU surfaces were modified with the compounds and analyzed.
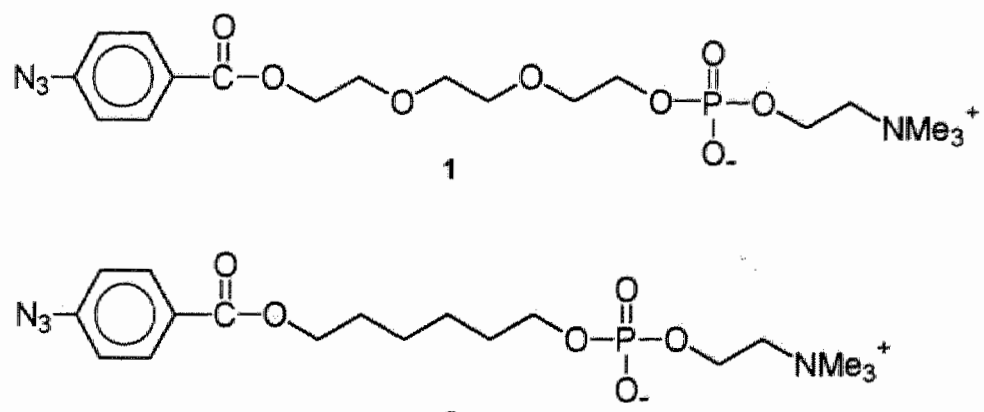


\section{Experimental}

\section{General}

NMR spectra were recorded on a Varian Unity-Plus $400 \mathrm{MHz}$ spectrometer

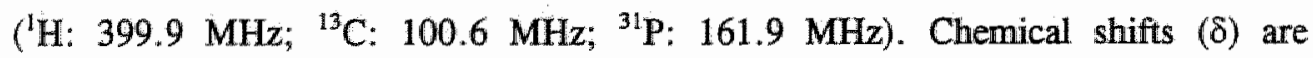
expressed in ppm downfield from internal tetramethylsilane $\left({ }^{1} \mathrm{H}\right.$ and $\left.{ }^{13} \mathrm{C} \mathrm{NMR}\right)$ or external $85 \%$ phosphoric acid $\left({ }^{31} \mathrm{P}\right.$ NMR). Column chromatography was carried out with Merck silica gel $60(0.063-0.200 \mathrm{~mm})$. TLC was performed with Merck silica gel $60 \mathrm{~F}_{254}$ on aluminium sheets. Tetrahydrofuran and diethylether were distilled from $\mathrm{CaH}_{2}$ prior to use. Pyridine was distilled from $\mathrm{KOH}$ and triethylamine from $\mathrm{CaH}_{2}$. 2-(Methylamino)ethanol was distilled from $\mathrm{CaH}_{2}$ under reduced pressure and stored under nitrogen. Ethyl acetate, petroleumether (PE, bp $40-65^{\circ} \mathrm{C}$ ), n-hexane, dichloromethane, toluene, acetonitrile, and methanol were of p.a. quality and used as received.

\section{Synthesis}

4-Axidobenzoyl chloride (3) 4-Aminobenzoic acid (11.0 g, $80.0 \mathrm{mmol}$ ) was dissolved in $64 \mathrm{ml} \mathrm{H} \mathrm{H}_{2} \mathrm{O}+16 \mathrm{ml} \mathrm{36 \%} \mathrm{HCl}(186 \mathrm{mmol} \mathrm{HCl})$. The solution was cooled with an ice bath and a solution of $\mathrm{NaNO}_{2}(5.52 \mathrm{~g}, 80.0 \mathrm{mmol})$ in $20 \mathrm{ml}$ of $\mathrm{H}_{2} \mathrm{O}$ was added at such a rate that the temperature did not exceed $5^{\circ} \mathrm{C}$. A solution of $\mathrm{NaN}_{3}(5.72 \mathrm{~g}, 88.0 \mathrm{mmol})$ in $20 \mathrm{ml}$ of $\mathrm{H}_{2} \mathrm{O}$ was added slowly, keeping the temperature below $5{ }^{\circ} \mathrm{C}$. At the same time $50 \mathrm{ml}$ of ethyl acetate was added to prevent product precipitation. Large amounts of nitrogen gas evolved from the solution. After stirring for $1 \mathrm{~h}$ the reaction mixture was extracted with $100 \mathrm{mi}$ of ethyl acetate. The organic layer was separated and extracted with $100 \mathrm{ml} 1 \mathrm{M}$ $\mathrm{NaOH}$. The water layer was neutralized with $100 \mathrm{ml} 1 \mathrm{M} \mathrm{HCl}$ and extracted with $100 \mathrm{ml}$ of ethyl acetate. After evaporation 4-azidobenzoic acid was obtained as a pale yellow solid $\left(12.0 \mathrm{~g}, 92 \%\right.$ yield, mp $183-185^{\circ} \mathrm{C}$ (dec.), lit. ${ }^{13}: \mathrm{mp} 185^{\circ} \mathrm{C}$ ). IR $(\mathrm{KBr}) \mathrm{cm}^{-1}$ : 3100-2500 (broad, O-H), $2110\left(\mathrm{~N}_{3}\right), 1680(\mathrm{C}=\mathrm{O}), 1300(\mathrm{C}-\mathrm{O}) .{ }^{1} \mathrm{H}$ NMR (d $\left.{ }_{6}-\mathrm{DMSO}\right): \delta 7.20(2 \mathrm{H}, \mathrm{d}$, ar $\mathrm{H}), 7.95(2 \mathrm{H}, \mathrm{d}$, ar $\mathrm{H}), 12.95(1 \mathrm{H}$, bs, $\mathrm{COOH}$ ). 
Thionylchloride $(6.57 \mathrm{~g}, 55.2 \mathrm{mmol})$ was added to a solution of 4-azidobenzoic acid $(3.0 \mathrm{~g}, 18.4 \mathrm{mmol})$ in $100 \mathrm{ml}$ of tetrahydrofuran. After refluxing for $0.5 \mathrm{~h}$ the solution was evaporated. Crystallization from $\mathrm{n}$-hexane afforded $\mathbf{3}$ as a yellow solid $\left(2.96 \mathrm{~g}, 89 \%, \mathrm{mp} 54-56{ }^{\circ} \mathrm{C}\right.$, lit. $\left.{ }^{13}: \mathrm{mp} 57-58{ }^{\circ} \mathrm{C}\right) .{ }^{1} \mathrm{H} \mathrm{NMR}\left(\mathrm{CDCl}_{3}\right): \delta 7.10(2 \mathrm{H}$, d, ar H), $8.10(2 \mathrm{H}, \mathrm{d}$, ar H).

Triethylene glycol trityl ether (4) Triethylene glycol (12.0 g, $84.0 \mathrm{mmol})$ was dissolved in $30 \mathrm{ml}$ of pyridine. After evaporating about $10 \mathrm{ml}$ of pyridine (azeotropic drying) a solution of triphenylmethyl chloride $(2.33 \mathrm{~g}, 8.37 \mathrm{mmol})$ in $10 \mathrm{ml}$ of pyridine was added slowly during $3 \mathrm{~h}$. The solution was stirred for $16 \mathrm{~h}$ after which pyridine was evaporated and coevaporated with toluene (twice). The residue was dissolved in dichloromethane and washed with $0.1 \mathrm{M}$ citric acid, saturated $\mathrm{NaHCO}_{3}$, and brine. Column chromatography (gradient PE/EtOAc 1:1 $\mathrm{w} / \mathrm{v} \rightarrow$ EtOAc, $\mathbf{R}_{f}$ (EtOAc) 0.47) yielded 4 as a colorless viscous oil $(3.0 \mathrm{~g}, 91 \%$, based on triphenylmethylchloride). ${ }^{1} \mathrm{H} \mathrm{NMR}\left(\mathrm{CDCl}_{3}\right): \delta 2.95(1 \mathrm{H}$, br s, OH$), 3.25(2 \mathrm{H}, \mathrm{t}$, $\left.\mathrm{CH}_{2} \mathrm{OCPh}_{3}\right), 3.58\left(2 \mathrm{H}, \mathrm{m}, \mathrm{CH}_{2}\right), 3.65\left(8 \mathrm{H}, \mathrm{m}, 4 \times \mathrm{CH}_{2}\right), 7.20(3 \mathrm{H}, \mathrm{m}$, ar $\mathrm{H}), 7.28$ $(6 \mathrm{H}, \mathrm{m}$, ar $\mathrm{H}), 7.48(6 \mathrm{H}, \mathrm{m}, \operatorname{ar} \mathrm{H})$.

Hexanediol trityl ether (5) This compound was synthesized in the same way as 4 , using hexanediol $(14.8 \mathrm{~g}, 125 \mathrm{mmol})$ and triphenylmethyl chloride $(6.96 \mathrm{~g}, 24.9$ mmol). After column chromatography (PE/EtOAc 7:3 v/v, $R_{\mathrm{f}} 0.21$ ) pure 5 was obtained as a white solid $(6.89 \mathrm{~g}, 77 \%)$. ${ }^{1} \mathrm{H}$ NMR $\left(\mathrm{CDCl}_{3}\right): 81.35(4 \mathrm{H}, \mathrm{m}, 2 \times$ $\left.\mathrm{CH}_{2}\right), 1.60\left(4 \mathrm{H}, \mathrm{m}, 2 \times \mathrm{CH}_{2}\right), 3.05\left(2 \mathrm{H}, \mathrm{t}, \mathrm{CH}_{2} \mathrm{OCPh}_{3}\right), 3.60\left(2 \mathrm{H}, \mathrm{t}, \mathrm{CH}_{2} \mathrm{OH}\right), 7.20$ $(9 \mathrm{H}, \mathrm{m}$, ar H), $7.50(6 \mathrm{H}, \mathrm{m}$, ar $\mathrm{H})$.

Hexanediol 4-azidobenzoate (6) 4-Azidobenzoylchloride (3) (1.28 g, 7.05 mmol) and 5 (2.26 g, $6.27 \mathrm{mmol})$ were dissolved in $20 \mathrm{ml}$ of pyridine. After stirring for $16 \mathrm{~h}$ pyridine was evaporated and coevaporated with toluene (twice). The residue was dissolved in ethyl acetate and washed with $0.1 \mathrm{M}$ citric acid, saturated $\mathrm{NaHCO}_{3}$, and brine. Column chromatography (PE/EtOAc 9:1 v/v, $R_{f} 0.51$ ) yielded the intermediate product as a yellow oil $(2.79 \mathrm{~g}, 88 \%)$. This was dissolved in a mixture of $8 \mathrm{ml}$ of dichloromethane and $2 \mathrm{ml}$ of methanol after which zinc bromide $(3.1 \mathrm{~g}$, $13.8 \mathrm{mmol}$ ) was added. The mixture was stirred for $15 \mathrm{~min}$ and evaporated. The 
residue was dissolved in ethyl acetate and washed with water and brine. Purification by column chromatography (PE/EtOAc $8: 2 v / v, R_{f} 0.20$ ) provided 6 as a pale yellow oil $(1.05 \mathrm{~g}, 73 \%)$. ${ }^{1} \mathrm{H}$ NMR (d 6 -DMSO): $81.40\left(6 \mathrm{H}, \mathrm{m}, 3 \times \mathrm{CH}_{2}\right), 1.70(2 \mathrm{H}, \mathrm{m}$, $\left.\mathrm{CH}_{2}\right), 3.40\left(2 \mathrm{H}, \mathrm{q}, \mathrm{CH}_{2} \mathrm{OH}\right), 4.25\left(2 \mathrm{H}, \mathrm{t}, \mathrm{COOCH}_{2}\right), 4.35(1 \mathrm{H}, \mathrm{t}, \mathrm{OH}), 7.22(2 \mathrm{H}$, d, ar H), $7.98(2 \mathrm{H}, \mathrm{d}$, ar H).

\section{1-O-(3-Methyl-2-oxo-1,3,2-oxazaphospholidin-2-yloxy)-hexanediol 4-azido-} benzoate $(7)$ Phosphorus oxychloride $(0.73 \mathrm{~g}, 4.78 \mathrm{mmol})$ and triethylamine $(0.27$ $\mathrm{g}, 2.60 \mathrm{mmol}$ ) were dissolved in $6 \mathrm{ml}$ of dichloromethane. The mixture was cooled to $0{ }^{\circ} \mathrm{C}$ and a solution of $6(1.05 \mathrm{~g}, 3.98 \mathrm{mmol})$ and triethylamine $(0.70 \mathrm{~g}, 7.00$ $\mathrm{mmol}$ ) in $12 \mathrm{ml}$ of dichloromethane was added slowly during $30 \mathrm{~min}$. After stirring an additional $30 \mathrm{~min}$ at room temperature the solution was cooled again to $0{ }^{\circ} \mathrm{C}$ and a solution of 2 -(methylamino)ethanol $(0.39 \mathrm{~g}, 5.30 \mathrm{mmol}$ ) and triethylamine $(1.46 \mathrm{~g}$, $14.4 \mathrm{mmol}$ ) in $15 \mathrm{ml}$ of dichloromethane was added slowly during $30 \mathrm{~min}$. After stirring for another $30 \mathrm{~min}$ at room temperature the mixture was filtered and evaporated. The residue was dissolved in dichloromethane/ether $1: 1 \mathrm{v} / \mathrm{v}$ and filtered again. Purification was accomplished by column chromatography $\left(\mathrm{CH}_{2} \mathrm{Cl}_{2} / \mathrm{MeOH}\right.$ 97:3 v/v plus a trace of $\mathrm{NEt}_{3}, \mathrm{R}_{\mathrm{f}} 0.31$ ), yielding 7 as a pale yellow oil $(1.04 \mathrm{~g}$, $68 \%) .{ }^{31} \mathrm{P} \mathrm{NMR}\left(\mathrm{CDCl}_{3}\right): \delta 22.3 .{ }^{1} \mathrm{H} \mathrm{NMR}\left(\mathrm{CDCl}_{3}\right): \delta 1.50\left(4 \mathrm{H}, \mathrm{m}, 2 \times \mathrm{CH}_{2}\right), 1.75$ $\left(4 \mathrm{H}, \mathrm{m}, 2 \times \mathrm{CH}_{2}\right), 2.69(3 \mathrm{H}, \mathrm{d}, \mathrm{NMe}), 3.31\left(2 \mathrm{H}, \mathrm{m}, \mathrm{CH}_{2} \mathrm{~N}\right), 4.02(2 \mathrm{H}, \mathrm{q}$, hexyl $\left.\mathrm{CH}_{2} \mathrm{OP}\right), 4.20\left(1 \mathrm{H}, \mathrm{m}, \mathrm{OCHHCH}_{2} \mathrm{~N}\right), 4.31\left(3 \mathrm{H}, \mathrm{m}, \mathrm{OCHHCH}_{2} \mathrm{~N}+\mathrm{COOCH}_{2}\right)$, $7.07(2 \mathrm{H}, \mathrm{d}$, ar $\mathrm{H}), 8.01(2 \mathrm{H}, \mathrm{d}$, ar $\mathrm{H})$.

1-O-(2-(Trimethylammonium)ethylphosphoryl)-hexanediol 4-azidobenzoate (2) Trifluoroacetic acid $(0.01 \mathrm{~g}, 0.10 \mathrm{mmol})$ was added to a solution of $7(1.04 \mathrm{~g}$, $2.72 \mathrm{mmol}$ ) in acetone/water $6: 1 \mathrm{v} / \mathrm{v}$. The solution was stirred for $1 \mathrm{~h}$, evaporated, and coevaporated with acetonitrile. The residue was dissolved in $20 \mathrm{ml}$ of methanol. Dimethylsulfate $(0.75 \mathrm{~g}, 5.98 \mathrm{mmol})$ and diisopropylamine $(1.06 \mathrm{~g}, 8.19 \mathrm{mmol})$ were added to the solution. After stirring for $6 \mathrm{~h}$ the reaction was quenched by adding ammonia $\left(1.0 \mathrm{ml} 25 \%, 13.4 \mathrm{mmol} \mathrm{NH}_{3}\right)$. The solution was evaporated and coevaporated with acetonitrile. Column chromatography $\left(\mathrm{MeOH} / \mathrm{H}_{2} \mathrm{O}\right.$ 9:1 v/v, $\mathrm{R}_{\mathrm{f}}$ $0.15)$ afforded pure 2 as a pale yellow solid $(0.86 \mathrm{~g}, 74 \%) .{ }^{3 i} \mathrm{P}$ NMR $\left(\mathrm{d}_{6}-\mathrm{DMSO}\right): \delta$ 0.48. ${ }^{1} \mathrm{H}$ NMR $\left(\mathrm{d}_{6}\right.$-DMSO): $\delta 1.37\left(4 \mathrm{H}, \mathrm{m}, 2 \mathrm{x}\right.$ hexyl $\left.\mathrm{CH}_{2}\right), 1.49(2 \mathrm{H}, \mathrm{m}$, hexyl 
$\left.\mathrm{CH}_{2} \mathrm{CH}_{2} \mathrm{OP}\right), 1.70\left(2 \mathrm{H}, \mathrm{m}, \mathrm{COOCH}_{2} \mathrm{CH}_{2}\right), 3.14\left(9 \mathrm{H}, \mathrm{s}, \mathrm{NMe}_{3}\right), 3.52(2 \mathrm{H}$, br t, $\left.\mathrm{CH}_{2} \mathrm{~N}\right), 3.60\left(2 \mathrm{H}, q, \mathrm{CH}_{2} \mathrm{OP}\right), 4.00\left(2 \mathrm{H}\right.$, br m, POCH$\left.{ }_{2} \mathrm{CH}_{2} \mathrm{~N}\right), 4.25(2 \mathrm{H}, \mathrm{t}$, $\left.\mathrm{COOCH}_{2}\right), 7.25(2 \mathrm{H}, \mathrm{d}$, ar $\mathrm{H}), 7.98\left(2 \mathrm{H}, \mathrm{d}\right.$, ar H). ${ }^{13} \mathrm{C}$ NMR $\left(\mathrm{d}_{6}-\mathrm{DMSO}\right): \delta 25.2$ (2C), 28.2, 30.4, 53.0, 58.2, 63.7, 64.7, 65.4, $119.4(2 \mathrm{C}), 126.3,131.0(2 \mathrm{C})$, $144.3,165.0$.

1-O-(2-(Trimethylammonium)ethylphosphoryl)-triethylene glycol 4-azidobenzoate (1) Synthesis of this compound proceeded like that of 2 (starting with 4 ). Pure 1 was obtained after column chromatography $\left(\mathrm{MeOH} / \mathrm{H}_{2} \mathrm{O} 9: 1 \mathrm{v} / \mathrm{v}, \mathrm{R}_{\mathrm{f}} 0.14\right)$ as a pale yellow oil $(0.93 \mathrm{~g}) .{ }^{31} \mathrm{P}$ NMR $\left(\mathrm{d}_{6}-\mathrm{DMSO}\right): \delta 0.23 .{ }^{1} \mathrm{H}$ NMR $\left(\mathrm{d}_{6}-\mathrm{DMSO}\right): \delta$ $3.12\left(9 \mathrm{H}, \mathrm{s}, \mathrm{NMe}_{3}\right), 3.49\left(4 \mathrm{H}, \mathrm{m}, \mathrm{CH}_{2} \mathrm{~N}\right.$ and $\left.\mathrm{OCH}_{2} \mathrm{CH}_{2} \mathrm{OP}\right), 3.53$ and $3.58(4 \mathrm{H}, 2$ $\left.\mathrm{x} \mathrm{m}, 2 \times \mathrm{CH}_{2} \mathrm{O}\right), 3.70\left(2 \mathrm{H}, \mathrm{q}, \mathrm{OCH}_{2} \mathrm{CH}_{2} \mathrm{OP}\right), 3.74\left(2 \mathrm{H}, \mathrm{t}, \mathrm{COOCH}_{2} \mathrm{CH}_{2} \mathrm{O}\right), 4.02$ $\left(2 \mathrm{H}\right.$, br m, $\left.\mathrm{POCH}_{2} \mathrm{CH}_{2} \mathrm{~N}\right), 4.38\left(2 \mathrm{H}, \mathrm{t}, \mathrm{COOCH}_{2}\right), 7.28(2 \mathrm{H}, \mathrm{d}, \mathrm{ar} \mathrm{H}), 7.98(2 \mathrm{H}, \mathrm{d}$, ar H). ${ }^{13} \mathrm{C}$ NMR (d $\mathrm{d}_{6}$-DMSO): $\delta 53.1,58.2,63.3,64.1,65.5,68.3,69.6,69.9,70.6$, $119.4(2 \mathrm{C}), 126.0,131.1(2 \mathrm{C}), 144.4,165.0$.

\section{Surface modification}

Poly(ether urethane) foil (Pellethane 2363-55D, Dow Chemical Inc., thickness $0.13 \mathrm{~mm}$ ) was ultrasonically cleaned with isopropanol, water, and ethanol and dried in vacuo. A $5 \mathrm{mM}$ solution of compound 2 (or 1 ) in isopropanol was sprayed onto the surface ten times, drying with hot air in between. UV irradiation was performed at a distance of $40 \mathrm{~cm}$ for 20 min with a medium-pressure metal halide lamp emitting radiation mainly between 300 and $400 \mathrm{~nm}$. The foil was washed and dried as before. One surface (surface (d), Table 1) was modified three times according to this procedure to obtain higher surface concentrations. 


\section{Surface characterization}

\section{Contact angles}

Surfaces were cut into pieces measuring $15 \times 5 \mathrm{~mm}^{2}$. After ultrasonically cleaning with isopropanol and water they were equilibrated in pure water for at least $14 \mathrm{~b}$. The surfaces were transferred into the transparent sample holder (polystyrene) that was filled with pure water. Multiple air bubbles $(1 \mu \mathrm{l})$ were introduced through a U-shaped needle underneath each floating polymer surface and viewed with a microscope (magnification 40x). Contact angles were determined with the goniometer present in the ocular and also by measuring the dimensions of the air bubble with the help of a movable cross-hair that was attached to a micrometer. The latter method gives more accurate results (using the formula in Table 1).

\section{ESCA}

ESCA (electron spectroscopy for chemical analysis) data were obtained with a Leybold MAX200 instrument using $\mathrm{Mg} \mathrm{K \alpha}(1253.6 \mathrm{eV})$ radiation. A surface area of $7 \times 4 \mathrm{~mm}^{2}$ was analyzed. The take-off angle between the sample and the spectrometer was $90^{\circ}$. Narrow-scan spectra were used to determine the area under each elemental peak. The measurements were performed as described previously. ${ }^{5}$

\section{Hemocompatibility measurements}

Thrombin generation assays were carried out on all modified surfaces. Blood was taken by venipuncture of a healthy donor who had not taken aspirin or other anti-coagulants for at least one week. The blood was anti-coagulated with $130 \mathrm{mM}$ trisodium citrate (1 part to 9 parts of blood) and centrifuged at $250 \mathrm{~g}$ for $15 \mathrm{~min}$ to obtain platelet-rich plasma. Surfaces were kept in a phosphate-buffered saline solution (PBS: $136 \mathrm{mM} \mathrm{NaCl}, 6.5 \mathrm{mM} \mathrm{Na}_{2} \mathrm{HPO}_{4} .12 \mathrm{H}_{2} \mathrm{O}, 1.5 \mathrm{mM} \mathrm{KH}_{2} \mathrm{PO}_{4}$, and 2.7 $\mathrm{mM} \mathrm{KCl}$; $\mathrm{pH} 7.4$ ) for $14 \mathrm{~h}$ and then incubated with the plasma for $15 \mathrm{~min}$ at $37^{\circ} \mathrm{C}$ after which recalcification with $0.5 \mathrm{M} \mathrm{CaCl}_{2}$ (final free $\mathrm{Ca}^{2+}$ concentration $4 \mathrm{mM}$ ) initiated clot formation. Thrombin generation was measured as described by Hemker et all. ${ }^{20}$ 
Platelet adhesion was studied with SEM (scanning electron microscopy). Polymer surfaces were kept in PBS buffer for $14 \mathrm{~h}$ and then incubated with citrated PRP for $30 \mathrm{~min}$ at $37^{\circ} \mathrm{C}$ in a 24 -well plate under very gentle shaking conditions. Then they were gently rinsed with (isotonic) PBS buffer after which the adhered cells were fixated with glutaric dialdehyde solution (2.5\% in PBS buffer) for $14 \mathrm{~h}$. The surfaces were rinsed with PBS buffer and dehydrated with a series of ethanol/water mixtures of increasing ethanol concentration $(15,50,75,95$, and $100 \%$ ethanol; $10 \mathrm{~min}$ in each mixture), followed by critical-point drying with $\mathrm{CO}_{2}$. The samples were sputter-coated with gold and viewed by a scanning electron microscope (Philips SEM 505 model).

\section{Results}

\section{Synthesis}

Both of the synthesized compounds contain a para-azidobenzoyl group that can be photochemically activated (vide infra). A short spacer chain (triethylene glycol for compound 1 and hexanediol for 2; the optimal spacer length is unknown) separates this group from the phosphorylcholine group. The triethylene glycol group in compound 1 could amplify the ability of phosphorylcholine to bind water.
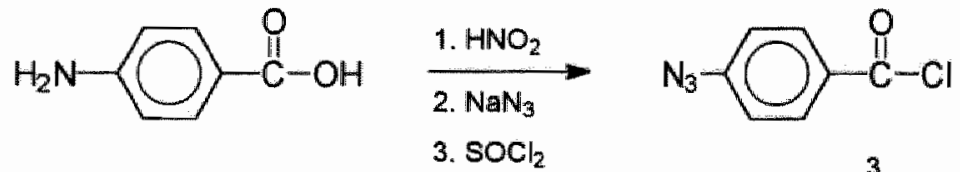

$\mathrm{H}-\left(\mathrm{OCH}_{2} \mathrm{CH}_{2}\right)_{3}-\mathrm{OH}$

$\mathrm{Ph}_{3} \mathrm{CCl}$

$\mathrm{H}-\left(\mathrm{OCH}_{2} \mathrm{CH}_{2}\right)_{3}-\mathrm{OCPh}_{3}$

4

$\mathrm{HO}-\left(\mathrm{CH}_{2}\right)_{6}-\mathrm{OH}$

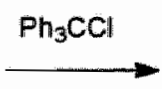

$\mathrm{HO}-\left(\mathrm{CH}_{2}\right)_{6}-\mathrm{OCPh}_{3}$ 
Synthesis of the compounds starts with converting 4-aminobenzoic acid into 4 azidobenzoic acid by a standard diazotation reaction with sodium nitrite in dilute hydrochloric acid, followed by addition of sodium azide. ${ }^{12}$ Reaction with thionyl chloride yields 4 -azidobenzoyl chloride 3 (Scheme 1). ${ }^{13}$ The second building block, mono-protected diol, is prepared from triethylene glycol or hexanediol by reacting it with triphenylmethyl chloride in a ratio of $10: 1$, yielding $\mathbf{4}$ and 5 respectively (Scheme 1). Coupling of the two building blocks proceeds smoothly in pyridine (Scheme 2, only synthesis of target compound 2 shown). Removal of the triphenylmethyl protecting group with the mild Lewis acid zinc bromide affords 6 . Reaction with phosphorus oxychloride followed by 2-(methylamino)ethanol yields cyclic phosphorus compound $7 .^{14}$ Selective hydrolysis of this compound can be performed with a trace amount of acid. The basicity of the nitrogen atom and the high stability of the $\mathrm{P}-\mathrm{O}$ bond are responsible for this selectivity. Methylation with dimethyl sulfate in basic solution results in the formation of target compound 2 . It is remarkable that an azidophenyl group can survive some of the harsh reaction conditions during the synthesis; it can withstand strong acids, nucleophiles, and methylating agents. ${ }^{15}$

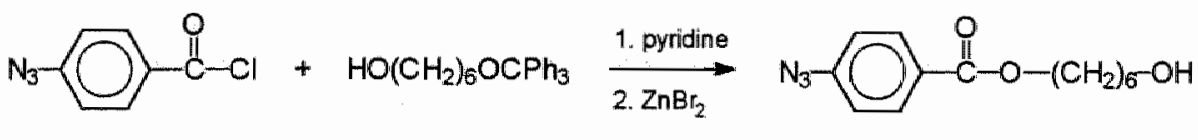

3

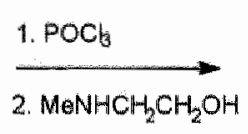<smiles>CC(=O)c1ccc(N)cc1</smiles>

$\underset{\text { 2. } \mathrm{Me}_{2} \mathrm{SO}_{4}}{\stackrel{\mathrm{H}^{+}}{-}}$

7

Scheme 2 


\section{Surface modification}

Although the photochemistry of aryl azides is complex, a substantial part of the mechanisms involved has been elucidated; however, the outcome of any photoreaction involving aryl azides is highly dependent on reaction conditions, substituents on the phenyl ring, and the availability of nucleophiles. ${ }^{15,16}$ Upon UV irradiation nitrogen $\left(\mathrm{N}_{2}\right)$ splits off and the highly reactive intermediate 8 - a singlet nitrene - is formed. The main reaction path followed by this intermediate in the presence of nucleophiles is shown in Scheme 3. The unstable singlet nitrene quickly rearranges to the didehydroazepine 9 , which is still a reactive compound (with a lifetime of a few milliseconds ${ }^{17}$ ) because of the unstable ketenimine fragment. Reaction with a nucleophile yields the azepine 10. In the surface modification of a $\mathrm{PEU}$ the urethane NH or the pendent $\mathrm{OH}$ groups can serve as nucleophilic groups. The presence of the electron-withdrawing para-carboxyl group on the phenyl ring of aryl azides $\mathbf{1}$ and $\mathbf{2}$ increases the reactivity of the cyclic ketenimine intermediate $\mathbf{9}$. It is known that this intermediate is sufficiently electrophilic to react with alcohols. ${ }^{18}$

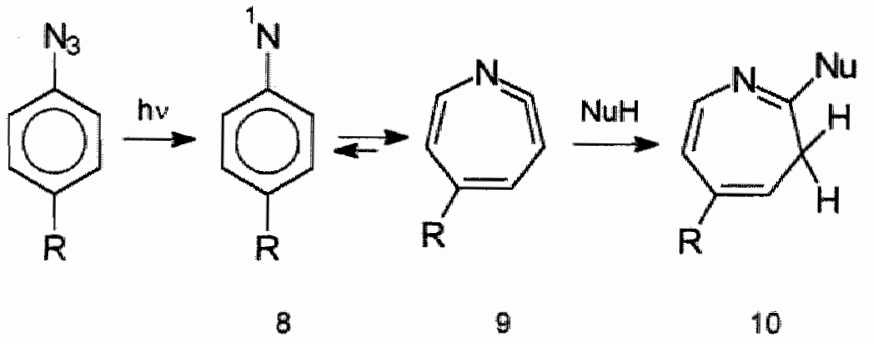

Scheme 3

The surface modification procedure starts with spraying a PEU foil (Pellethane 2363-55D) with a $5 \mathrm{mM}$ solution of compound 1 or 2 in isopropanol, followed by drying. This process results in a physically adsorbed layer of the aryl azide on the polymer sheet. Upon irradiation with UV light (300-400 nm) covalent bonds are formed between the compound and the reactive groups on the polymer surface. After extensive washing the procedure can be repeated to attain higher surface concentrations of coupled molecules. 


\section{Surface analysis}

\section{Contact angles}

The captive bubble technique ${ }^{19}$ was used to determine underwater contact angles of the modified surfaces (Table 1). This technique gives a static contact angle that is comparable to the (dynamic) receding contact angle which is measured with the Wilhelmy method. ${ }^{19}$ All surfaces were kept in water for at least $14 \mathrm{~h}$ before contact angles were measured. Contact angles were determined from air bubbles introduced undemeath each polymer surface that was floating in water. The modified surfaces showed lower contact angles than the unmodified PEU, which indicates that hydrophillic phosphorylcholine groups were present at the surface. The lowest contact angle ( $\left(44^{\circ}\right)$ was found for the surface that was modified three times with compound 2. Apparently, not all of the available reactive groups at the polymer surface reacted after one modification passage.

Table 1. Contact angles

\begin{tabular}{lll}
\hline surface $^{*}$ & & $\theta_{c}(\text { s.d. })^{\dagger}$ \\
\hline PEU control & (a) & $58(2)$ \\
PEU + 1 & (b) & $53(2)$ \\
PEU + 2 & (c) & $50(2)$ \\
PEU + 2,3x & (d) & $44(3)$ \\
\hline
\end{tabular}

* PEU is Pellethane 2363-55D; surface (d) was modified three times (with compound 2).

${ }^{+}$Average of eight measurements with standard deviations in brackets. Angles were calculated according to the formula $\theta_{c}=\arccos (2 \mathrm{~h} / d-1)$, in which $h$ is the height and $d$ is the diameter of the air bubble.

\section{ESCA}

ESCA spectra were measured for all surfaces. From narrow-scan spectra the atomic composition of the surfaces was calculated (Table 2). The most obvious difference between a PEU and a modified surface is, of course, the appearance of phosphorus ( $\mathrm{P} 2 \mathrm{~s}$ and $\mathrm{P} 2 \mathrm{p}$ ) signals. Also, it can be seen that the $\mathrm{N}$ 1s signal consists of two parts (Fig. 1): a major peak at $400 \mathrm{eV}$ and a minor peak at $402 \mathrm{eV}$. The latter can be attributed to positively charged nitrogen atoms, i.e. quaternary ammonium 
groups. The $\mathrm{N}^{+}$concentrations should be equal to the $\mathrm{P}$ concentrations. From Table 2 it follows that, within the experimental error for these low concentrations of about $20 \%$, this is the case. This is a strong indication for the presence of phosphorylcholine groups at the polymer surface. Although it is not possible to determine absolute amounts of coupled molecules with ESCA, a qualitative comparison can be made with a theoretical surface consisting only of compound 1 or 2. The atomic composition of these compounds after irradiation (which results in the loss of two nitrogen atoms) also is given in Table 2. Looking at surface (d) for instance, it can be seen that $\mathrm{N}^{+}$and $\mathrm{P}$ concentrations are quite high (almost $50 \%$ of the theoretical values as they would appear on a surface consisting only of compound 2). For all surfaces $\mathrm{C}$ concentrations have decreased and $\mathrm{O}$ concentrations increased in comparison to PEU, as expected. The differences in $\mathrm{N}$ concentrations probably are due to experimental errors that can be as high as $20 \%$ for these low concentrations.

Table 2. ESCA analyses*

\begin{tabular}{llllllll}
\hline surface & & at\% C & at\% O & at\% $\mathrm{N}$ & at\% $\mathrm{N}^{+}$ & at\% $\mathrm{P}$ \\
\hline PEU control (a) & 81 & 16 & 2.9 & 0 & 0 \\
$\mathrm{PEU}+1$ & (b) & 76 & 20 & 3.2 & 0.6 & 0.8 \\
$\mathrm{PEU}+2$ & (c) & 73 & 21 & 2.9 & 1.1 & 1.5 \\
$\mathrm{PEU}+2,3 \mathrm{x}$ (d) & 73 & 21 & 2.6 & 1.2 & 1.8 \\
compound 1, theor. $^{+}$ & 62 & 28 & 3.5 & 3.5 & 3.4 \\
compound 2, theor. $^{\dagger}$ & 67 & 22 & 3.7 & 3.7 & 3.7
\end{tabular}

- ESCA measurements were performed at a take-off angle between the sample and the electron energy analyzer of $90^{\circ}$ (scanning depth about 50 A). Atom percentages were derived from $C 1 s, O 1 s, N 1 s$, and $P 2 p$ narrow-scan spectra.

$\dagger$ Theoretical values for a surface consisting only of this compound, after UV irradiation (i.e. after losing two nitrogen atoms). 


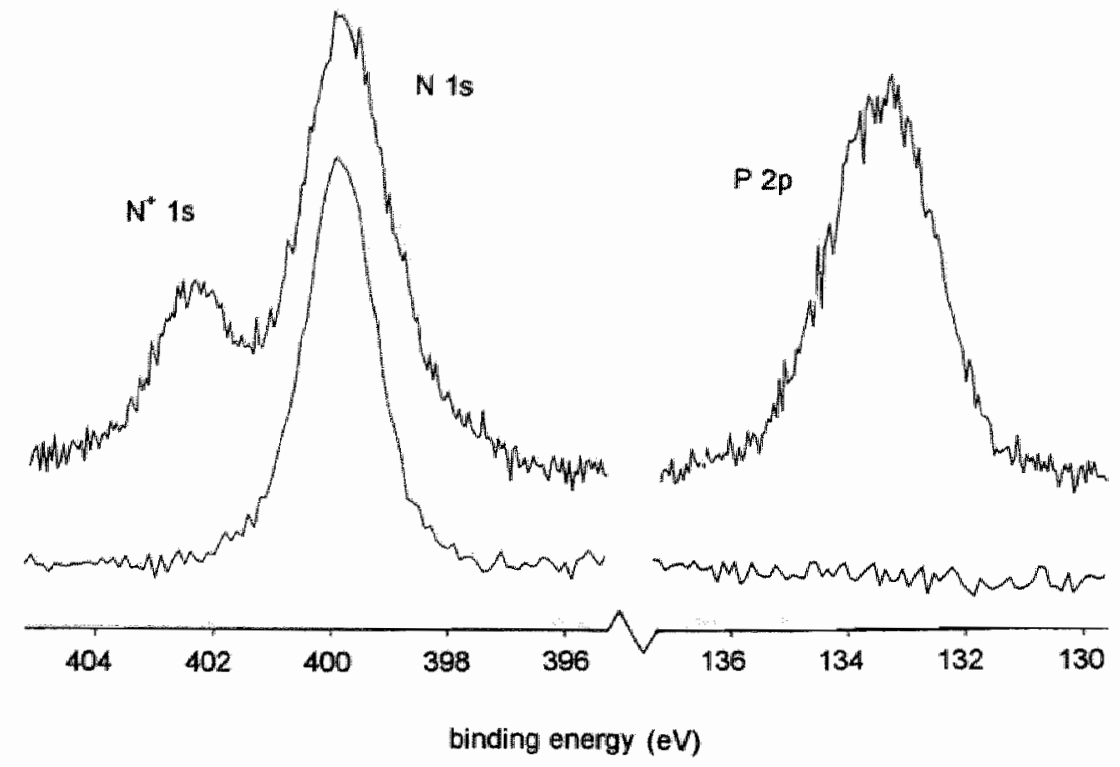

Figure 1. ESCA N 1s and P 2p narrow-scan spectra of the PEU surface modified with compound 2. The bottom spectrum shows the $\mathrm{N}$ 1s peak of unmodified PEU.

\section{Hemocompatibility in vitro}

Thrombin generation assays

In vitro thrombin generation tests were performed with the surfaces in order to determine blood clotting times and maximum thrombin concentrations reached in clotting blood. The procedure was described previously. ${ }^{20,4}$ In short, the polymer surfaces are incubated with citrated platelet-rich plasma (PRP) for $15 \mathrm{~min}$. Recalcification (final free $\mathrm{Ca}^{2+}$ concentration $4 \mathrm{mM}$ ) initiates clot formation. Subsamples are taken at regular time intervals and tested for thrombin, using thrombin-specific chromogenic substrate S2238 (H-D-phenylalanyl-pipecolylarginine $p$-nitroanilide). Thrombin splits off $p$-nitroaniline which is spectrophotometrically detected at $405 \mathrm{~nm}$. Thus a curve is obtained of the thrombin concentration as a function of time. After a lag phase the thrombin concentration suddenly will increase and pass through a maximum. The experimental thrombin generation curve is corrected for the residual amidolytical activity of the stable thrombin- $\alpha_{2}$-macroglobulin complex in order to obtain true thrombin concentrations. ${ }^{20}$ Two parameters can be derived from the curves. First, the lag time 
is determined, i.e. the time after which the thrombin concentration suddenly starts to increase. The lag time corresponds to the visually observed clotting time, as the increased thrombin concentration immediately leads to fibrin formation. Second, the maximum thrombin concentration is determined. In most cases the maximum thrombin concentration decreases as the clotting time increases. ${ }^{4,21}$

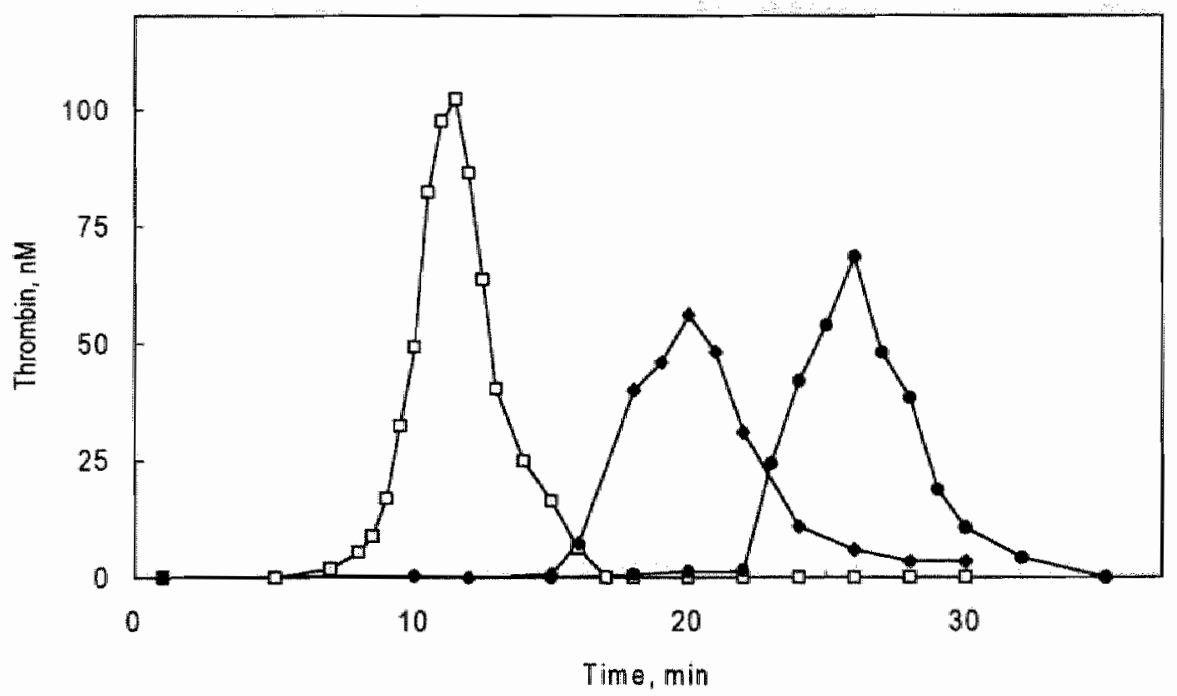

Figure 2. Thrombin generation curves for PEU ( $\square$ ), PEU modified with compound $\mathbf{2}(\bullet)$, and PEU modified three times with compound $\mathbf{2}(\bullet)$.

Figure 2 presents a selection of the thrombin generation curves obtained. From these curves the lag times (or clotting times) and maximum thrombin concentrations can be derived (Table 3 ). Note that the clotting time is confirmed by visual observation. The results show that clotting times are prolonged from $8.2 \mathrm{~min}$ for PEU (control surface) to $14.4 \mathrm{~min}$ for PEU modified with 1 and $16.1 \mathrm{~min}$ for PEU modified with 2 . The PEU surface that was modified three times with 2 (d) shows the highest clotting time: $22.0 \mathrm{~min}$. Maximum thrombin concentrations of the modified surfaces have decreased in comparison to the unmodified PEU. The maximum thrombin concentrations decrease as the clotting times increase, except for surface (d); a value of less than $56 \mathrm{nM}$ would be expected but $69 \mathrm{nM}$ is found. When compared to the clotting times for other polymers, the observed differences are 
significant. In a series of analogous experiments the following clotting times were found: polyethylene $5.7 \mathrm{~min}$, polypropylene $7.3 \mathrm{~min}$, polyurethane $8.0 \mathrm{~min}$, and polyvinylchloride-T 9.9 min. ${ }^{22}$ This series reflects an increasing thrombogenicity of the polymers (with polyethylene as the most thrombogenic material). A poly(ether urethane) surface that was modified with polyacrylamide to which heparin was coupled covalently, had a clotting time that varied between 10 and $26 \mathrm{~min}$, depending on the amount of heparin coupled. ${ }^{23}$

Table 3. Clotting times and maximum thrombin concentrations

\begin{tabular}{llll}
\hline surface & $\begin{array}{l}\mathrm{t}_{\text {clor }}(\mathrm{s.d.})^{\ddagger} \\
\text { min }\end{array}$ & $\begin{array}{l}\text { [thrombin }]_{\max }(\mathrm{s} . \text { d. })^{\ddagger} \\
\mathrm{nM}\end{array}$ \\
\hline PEU control (a) & $8.2(0.2)$ & $102(7)$ \\
$\mathrm{PEU}+1$ & (b) & $14.4(0.3)$ & $83(6)$ \\
$\mathrm{PEU}+2$ & (c) & $16.1(0.6)$ & $56(7)$ \\
$\mathrm{PEU}+2,3 \mathrm{x}$ & (d) & $22.0(0.4)$ & $69(2)$ \\
\hline
\end{tabular}

${ }^{\ddagger}$ Measurements were performed in triplicate (standard deviations in brackets).

\section{Platelet adhesion studies}

Modified surfaces that had been exposed to citrated platelet-rich plasma were prepared for scanning electron microscopy (SEM). Most of the platelets observed on the modified surfaces showed only little activation (Fig. 3). A number of platelets had short pseudopods and showed some aggregation and only a few platelets were spread. There was not much difference between the different modified surfaces. The number of adhered platelets on the unmodified PEU surface (Fig. 3a) looked considerably higher (although no attempt was made to count them) and they showed more activation. Many aggregates could be seen and most platelets had a number of pseudopods. On some areas of the surface fully spread platelets could be seen. 

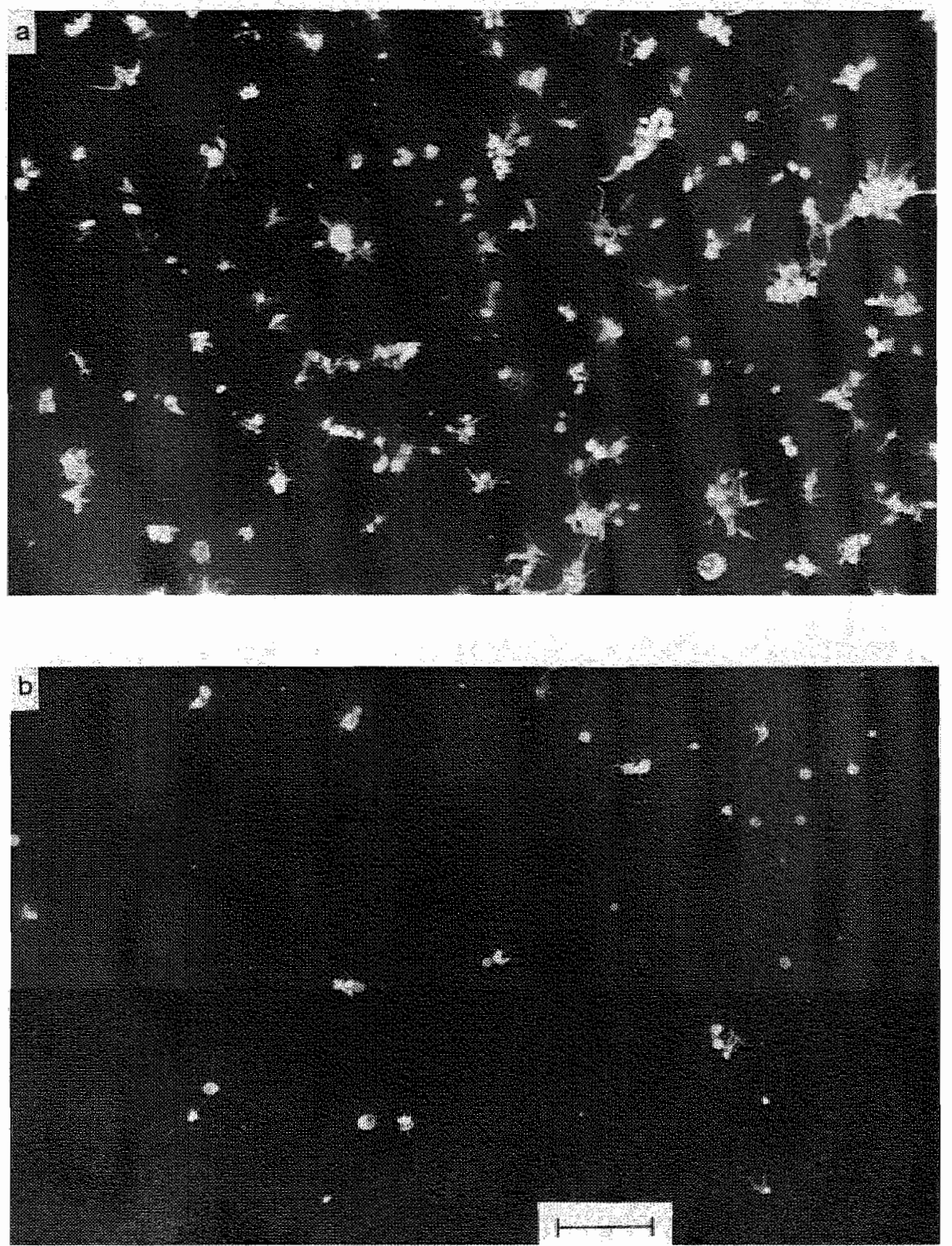

Figure 3. (continued on next page) SEM photographs of polymer surfaces that have been exposed to citrated PRP. (a) PEU (Pellethane 2363-55D); (b) PEU modified with compound 1. Length of bar $=20 \mu \mathrm{m}$. 

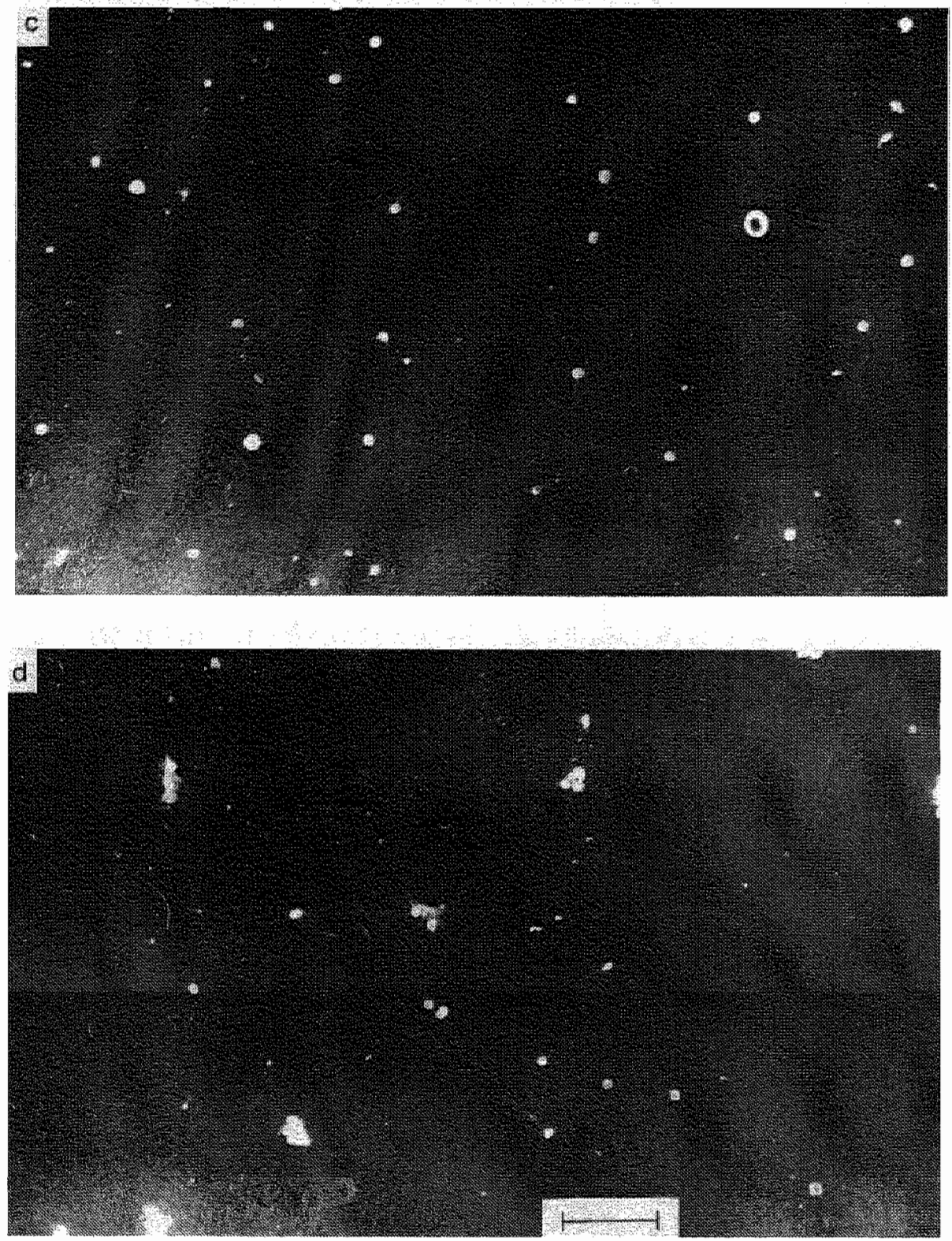

Figure 3. (continuation from previous page) SEM photographs of polymer surfaces that have been exposed to citrated PRP. (c) PEU modified with compound 2; (d) PEU modified three times with compound 2. Length of bar $=20 \mu \mathrm{m}$. 


\section{Discussion}

A photochemical method was devised in this laboratory for the surface modification of poly(ether urethanes) in order to improve hemocompatibility. Aryl azides were synthesized with a theophylline ${ }^{5}$ or dipyridamole ${ }^{4}$ endgroup. These compounds were successfully coupled to PEUs and shown to improve hemocompatibility. It was proven that the photochemical reaction of aryl azides with a PEU surface leads to covalently coupled molecules (Ch. 3). ${ }^{24}$ Aryl azides have been used before for the surface modification of polymeric materials. Copolymers made from p-azidostyrene and $\mathrm{N}, \mathrm{N}$-dimethyl acrylamide have been coupled to polyurethane and polystyrene. ${ }^{25,26}$ 4-Fluoro-3-nitrophenyl azide has been used to synthesize aryl azides containing poly(ethylene glycol) ${ }^{27}$ and heparin. ${ }^{28}$

Aryl azides containing phosphorylcholine endgroups have probably never been synthesized before. A method was presented here to synthesize these interesting compounds and to couple them to polyurethane surfaces. Chemical methods have been described to couple phosphorylcholine-containing molecules to surfaces. ${ }^{10}$ Phosphorylcholine groups also have been introduced into polymeric materials by incorporating them as monomers (2-methacryloyloxyethyl phosphorylcholine) during copolymerization. ${ }^{9}$

In conclusion, it was shown that aryl azides with phosphorylcholine endgroups can be used for the photochemical surface modification of poly(ether urethanes). Significant amounts of phosphorylcholine can be coupled to PEU in this way. The hemocompatibility of the modified surfaces was shown to be improved by this procedure. The concept of photo-immobilization of phosphorylcholine groups on PEU surfaces is particularly relevant to the development of functional small-bore vascular prostheses (vide supra). The need for these vascular grafts is especially felt in aortocoronary bypass surgery. In most cases, autologous vessels (saphenous veins) are used to construct the bypass but a number of patients lack autologous vessels of good quality. The Perma-Flow graft was designed specifically to address this problem. ${ }^{29}$ The PTFE (polytetrafluoroethylene) material from which this graft is constructed, however, is known to have a rather poor hemocompatibility. Poly(ether urethane) grafts have been developed with good mechanical matching to blood 
vessels. ${ }^{30}$ Surface modification of the luminal side of these grafts to obtain nearperfect hemocompatibility could result in a material that can be used in the clinic.

\section{References}

1. M.D. Lelah and S.L. Cooper, Polyurethanes in Medicine, Boca Raton, Florida, 1986.

2. T.G. Grasel, J.A. Pierce, and S.L. Cooper, "Effects of alkyl grafting on surface properties and blood compatibility of polyurethane block copolymers," J. Biomed. Mater. Res., 21, 815-842 (1987).

3. G.H. Engbers and J. Feijen, "Current techniques to improve the blood compatibility of biomaterial surfaces," Int. J. Antif. Organs, 14, 199-215 (1991).

4. Y.B.J. Aldenhoff and L.H. Koole, "Studies on a new strategy for surface modification of polymeric biomaterials," J. Biomed. Mater. Res., 29, 917-928 (1995).

5. J.M.H. Kuijpens, G.A. Kardaun, A.P. Pijpers, and L.H. Koole, "Immobilization of theophylline on medical-grade polyurethane inhibits surface-induced activation of blood platelets," J. Am. Chem. Soc., 117, 8691-8697 (1995).

6. J.A. Hayward and D. Chapman, "Biomembrane surfaces as models for polymer design: the potential for haemocompatibility," Biomaterials, 5, 135-142 (1984).

7. R.F.A. Zwaal and H.C. Hemker, "Blood cell membranes and haemostasis," Haemostasis, 11, 12-39 (1982).

8. E.M. Bevers, P. Comfurius, J.L.M.L. van Rijn, and R.F.A. Zwaal, "Generation of prothrombin-converting activity and the exposure of phosphatidylserine at the outer surface of platelets," Eur. J. Biochem., 122, 429-436 (1982).

9. K. Ishihara, T. Tsuji, T. Kurosaki, and N. Nakabayashi, "Hemocompatibility on graft copolymers composed of (2-methacryloyloxyethyl phosphorylcholine) side chain and poly(n-butyl methacrylate) backbone," J. Biomed. Mater. Res., 28, 225-232 (1994).

10. A.A. Durrani, J.A. Hayward, and D. Chapman, "Biomembranes as models for polymer surfaces. II. The syntheses of reactive species for covalent coupling of phosphorylcholine to polymer surfaces," Biomaterials, 7, 121-125 (1986).

11. D. Chapman, "Biomembranes and new hemocompatible materials," Langmuir, 9, 3945 (1993).

12. C.J. Shields, D.E. Falvey, G.B. Schuster, O. Buchardt, and P.E. Nielsen, "Competitive singlet-singlet energy transfer and electron transfer activation of aryl azides: application to photo-cross-linking experiments," J. Org. Chem., 53, 35013507 (1988).

13. S.H. Merrill and C.C. Unruh, "Photosensitive azide polymers," J. Appl. Polym. Sci., 7, 273-279 (1963).

14. H. Eibl, "Phospholipid synthesis: Oxazaphospholanes and dioxaphospholanes as intermediates," Proc. Natl. Acad. Sci. USA, 75, 4074-4077 (1978).

15. E.F.V. Scriven (ed.), Azides and Nitrenes, Academic Press, New York, 1984.

16. Y.-Z. Li, J.P. Kirby, M.W. George, M. Poliakoff, and G.B. Schuster, "1,2Didehydroazepines from the photolysis of substituted aryl azides: Analysis of their chemical and physical properties by time-resolved spectroscopic methods," J. Am. Chem. Soc., 110, 8092-8098 (1988). 
17. C.J. Shields, D.R. Chrisope, G.B. Schuster, A.J. Dixon, M. Poliakoff, and J.J. Turner, "Photochemistry of aryl azides: detection and characterization of a dehydroazepine by time-resolved infrared spectroscopy and flash photolysis at room temperature," J. Am. Chem. Soc., 109, 4723-4726 (1987).

18. P.E. Nielsen and O. Buchardt, "Aryl azides as photoaffinity labeis. A photochemical study of some 4-substituted aryl azides," Photochem. Photobiol., 35, 317-323 (1982).

19. J.D. Andrade, L.M. Smith, and D.E. Gregonis, in Surface and interfacial aspects of biomedical polymers. Vol. I. Surface chemistry and physics, J.D. Andrade (ed.), Plenum Press, New York, 1985, Chap. 7.

20. H.C. Hemker, G.M. Willems, and S. Béguin, "A computer-assisted method to obtain the prothrombin activation velocity in whole plasma independent of thrombin decay processes," Thromb. Haemostas., 56, 9-17 (1986).

21. M.A.B. Kruft, A. Benzina, F. Băr, F.H. van der Veen, C.W.M. Bastiaansen, R. Blezer, T. Lindhout, and L.H. Koole, "Studies on two new radiopaque polymeric biomaterials," J. Biomed. Mater. Res., 28, 1259-1266 (1994).

22. T. Lindhout, R. Blezer, C. Maassen, V. Heijnen, and C.P.M. Reutelingsperger, "Platelet procoagulant surface as an essential parameter for the in vitro evaluation of the blood compatibility of polymers," J. Mater. Sci.-Mater. M., 6, 367-372 (1995).

23. T. Lindhout, R. Blezer, P. Schoen, G.M. Willems, B. Fouache, M. Verhoeven, M. Hendriks, L. Cahalan, and P.T. Cahalan, "Antithrombin activity of surface-bound heparin studied under flow conditions, ${ }^{\prime} J$. Biomed. Mater. Res., 29, 1255-1266 (1995).

24. A.P. van der Heiden and L.H. Koole, "Photochemical coupling of aryl azides to poly(ether urethane) surfaces: studies with a fluorescent model compound," Macromolecules, 29, 7012-7015 (1996).

25. T. Matsuda and $\mathbf{K}$. Inoue, "Novel photoreactive surface modification technology for fabricated devices," Trans. Am. Soc. Artif. Intern. Organs, 36, M161-M164 (1990).

26. T. Matsuda and T. Sugawara, "Development of surface photochemical modification method for micropatterning of cultured cells," J. Biomed. Mater. Res., 29, 749-756 (1995).

27. Y.-C. Tseng and K. Park, "Synthesis of photoreactive poly(ethylene glycol) and its application to the prevention of surface-induced platelet activation," $J$. Biomed. Mater. Res., 26, 373-391 (1992).

28. M. Erdtmann, R. Keller, and H. Baumann, "Photochemical immobilization of heparin, dermatan sulphate, dextran sulphate and endothelial cell surface heparan sulphate onto cellulose membranes for the preparation of athrombogenic and antithrombogenic polymers," Biomaterials, 15, 1043-1048 (1994).

29. R.W. Emery, L.D. Joyce, K.V. Arom, R.M. King, and D.M. Nicoloff, "Operative considerations in implantation of the Perma-Flow graft," Ann. Thorac. Surg., 58, 1770-1773 (1994).

30. K. Fujimoto, M. Minato, S. Miyamoto, T. Kaneko, H. Kikuchi, K. Sakai, M. Okada, and Y. Ikada, "Porous polyurethane tubes as vascular graft," J. Appl. Biomater, , 4, 347-354 (1993). 


\section{Adsorption of Proteins onto Poly(ether urethane) with a Phosphorylcholine Moiety and Influence of Pre-adsorbed Phospholipid *}

\section{Abstract}

In the previous chapter it was demonstrated that the blood compatibility of poly(ether urethane) (PEU) can be improved by grafting phosphorylcholine (PC) groups on the surface. The improved blood compatibility was indicated by decreased platelet adsorption/activation and reduced thrombin formation at the polymer surface in experiments in which the surfaces were contacted with platelet-rich plasma in vitro. In the present study, protein and phospholipid adsorption was investigated on PEU surfaces grafted with PC groups. Adsorption of human fibrinogen ( $\mathrm{Fg}$ ), human serum albumin (Alb), human high molecular weight kininogen (HMWK), and dioleoyl phosphatidylcholine (DOPC) vesicles was measured by ellipsometry. For this purpose, thin PEU films were cast on silicon wafers. The polymer film was photochemically modified with a PC-containing aryl azide. The presence of $\mathrm{PC}$ groups on the polymer surface was demonstrated by ESCA (Electron Spectroscopy for Chemical Analysis). Hydrophilicity of the polymer surface increased by the surface modification, as indicated by a decrease in contact angle from $59^{\circ}$ before to $43^{\circ}$ after modification. The data show that the presence of PC groups has little effect on the adsorption of proteins to a PEU surface. The highest adsorption was observed for Fg $\left(0.49 \mu \mathrm{g} / \mathrm{cm}^{2}\right.$ on PC-modified PEU and $0.50 \mu \mathrm{g} / \mathrm{cm}^{2}$ on PEU), followed by HMWK $\left(0.28 \mu \mathrm{g} / \mathrm{cm}^{2}\right.$ on both PC-modified PEU and PEU), and $\mathrm{Alb}\left(0.16 \mu \mathrm{g} / \mathrm{cm}^{2}\right.$ on PC-modified PEU and $0.18 \mu \mathrm{g} / \mathrm{cm}^{2}$ on PEU). Protein adsorption was further studied on a "biomembrane-like" DOPC bilayer formed on hydrophilic silicon. Protein adsorption on this DOPC bilayer was absent. The adsorption of small unilamellar DOPC vesicles on the polymer surfaces amounted to about $0.06 \mu \mathrm{g} / \mathrm{cm}^{2}$ (corresponding to circa $30 \%$ of monolayer coverage) and was similar for PC-modified PEU and PEU. Despite this partial surface coverage, pre-adsorbed DOPC on the polymer surface diminished the subsequent adsorption of proteins considerably. These results show that the mere presence of phosphorylcholine groups on a PEU surface is insufficient to suppress protein adsorption (at least in single protein experiments). The highly ordered structure of natural phospholipid bilayers seems to be required to suppress protein adsorption effectively.

* A.P. van der Heiden, G.M. Willems, T. Lindhout, A.P. Pijpers, and L.H. Koole, $J$. Biomed. Mater. Res., in press (1997). 


\section{Introduction}

Poly(ether urethanes) (PEUs) are used extensively for the manufacture of bloodcontacting devices. The mechanical properties (toughness, durability, and resistance to flex-fatigue) of these polymers make them especially suitable for applications such as catheters, pacemaker leads, and vascular grafts. ${ }^{\text {II }}$ The moderate blood compatibility of PEUs is a major problem in (long-term) blood-contacting applications. It is for this reason that surface modification of these polymers has become an important topic in biomaterials science. The ultimate goal is to prepare a surface with near-perfect blood compatibility, while maintaining the mechanical properties of the polymer.

It is generally accepted that protein adsorption is the initial event in bloodmaterial interactions. ${ }^{2}$ Proteins adsorb to the surface, change their conformation, and can be exchanged by other plasma proteins. ${ }^{3}$ Platelet adhesion and activation is determined by the material's surface and the adsorbed proteins. Activated platelets amplify coagulation, resulting in the formation of a thrombus. A material that is designed for blood-contacting applications should cause minimal platelet activation. ${ }^{4}$

A variety of surface-modifying techniques has been developed. One particular strategy, which is being followed by several research groups, is based on the photochemical reactivity of compounds containing a azidophenyl group. ${ }^{5,6}$ Upon UV irradiation, these compounds are turned into reactive intermediates that can form covalent bonds with a polymer surface. In this laboratory work has been done on the photochemical surface modification of a PEU (Pellethane 2363-55D) with conjugate molecules containing a azidophenyl group at one end of the molecule and a pharmacologically active group, such as dipyridamole ${ }^{7}$ or theophylline, ${ }^{8}$ at the other end. It was further proven that this surface modification method indeed results in covalent coupling between the molecules and the polymer surface (Ch. 3$)^{9}$ 


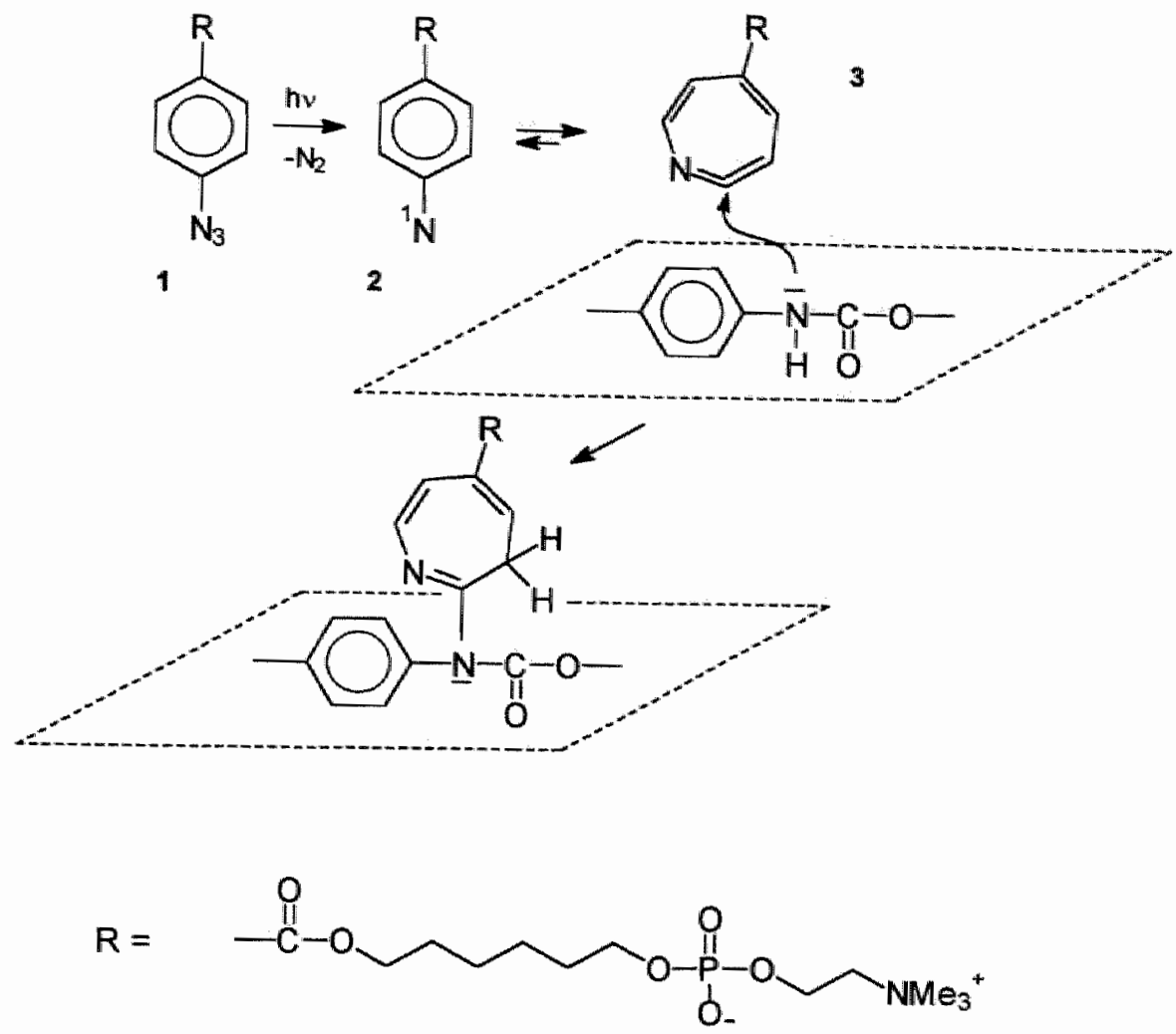

Figure 1. The photochemical reaction between compound 1 [1-O-(2-(trimethy]ammonium)ethylphosphoryl)-hexanediol 4-azidobenzoate] and poly(ether urethane). UV irradiation converts aryl azide 1 into the reactive singlet nitrene 2 . This molecule rearranges to the didehydroazepine 3 , which can react with weakly nucleophilic groups at the polymer surface (such as urethane NH groups). Phosphorylcholine groups are covalently immobilized on the polymer surface by this procedure.

In the previous chapter it was demonstrated how this photochemical surface modification method can be used to immobilize phosphorylcholine (PC) groups at a PEU surface. ${ }^{10}$ The photoreactive compound 1 (Fig. 1) was used for this purpose. The PC endgroup of this molecule is separated from the photoreactive azidophenyl group by a short hexyl spacer. UV irradiation leads to the formation of a covalent bond between the $\mathrm{PC}$-containing compound and, presumably, the urethane $\mathrm{NH}$ group of the polymer. It has been argued that PC groups on a polymer surface could, to some extent, mimic the outer phospholipid surface of red blood cells and blood platelets, resulting in "passivation" of the polymer towards protein adsorption and 
platelet adhesion/activation. "Several groups have prepared PC-containing polymers and demonstrated that these materials exhibit improved blood compatibility compared to the unimodified polymer..$^{12,13}$

It was demonstrated that the in vitro blood compatibility of PEU could be improved by grafting PC-containing compound 1 to the surface (Ch. 4). ${ }^{10}$ Observations by scanning electron microscopy (SEM) of polymer surfaces that were incubated with platelet-rich plasma showed that fewer platelets adhered to the PCmodified PEU surfaces (compared to unmodified PEU) and that the adhered platelets were less activated (as evidenced by less platelet aggregation and spreading). Thrombin generation assays ${ }^{14}$ with platelet-rich plasma showed that less thrombin was generated on the PC-modified surfaces, which also is an indication of improved blood compatibility. ${ }^{10}$

In the present work the investigation on the blood compatibility of PC-modified PEU surfaces was extended with a study of the protein adsorption. Ellipsometry was used to study the adsorption of three (human) plasma proteins: fibrinogen ( $\mathrm{Fg}$ ), albumin (Alb), and high molecular weight kininogen (HMWK). Also, the adsorption of dioleoyl phosphatidylcholine (DOPC) vesicles was studied and the effect of preadsorbed DOPC on protein adsorption. Five different surfaces, schematically depicted in Figure 2, were compared. All surfaces were prepared on silicon wafers because they present a smooth and reflective surface which is required for ellipsometric measurements. Protein adsorption onto a PEU film cast on silicon (Si-PEU) was compared to adsorption onto a similar film with PC groups covalently attached on its surface (Si-PEU-PC) (Fig. 2c and 2d, respectively). Further, the adsorption of proteins on an oxidized (hydrophilic) silicon surface (Fig. 2a) and a silanized (hydrophobic) silicon surface (Fig. 2b) was studied. For comparison, the adsorption of proteins onto a DOPC bilayer formed on hydrophilic silicon (Fig. 2e), which represents a model for the outer membrane surface of blood cells, was also investigated. 
"Si/SiO2"

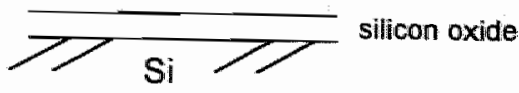

(a)

"Si-PEU"

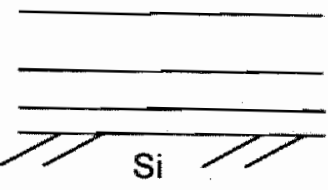

(c)
PEU

polysiloxane silicon oxide
"Si-polysiloxane"

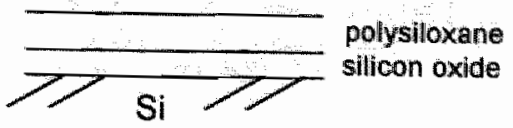

(b)

"SI-PEU-PC"

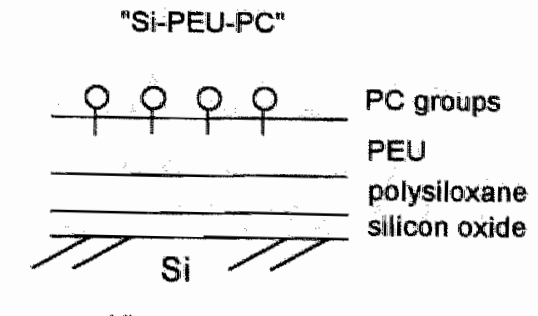

(d)

"Si/SiO2 + DOPC"

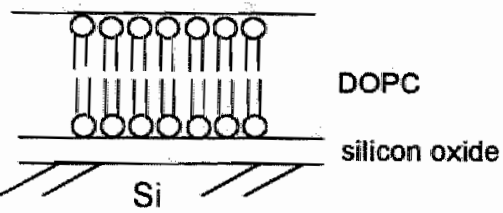

(e)

Figure 2. The five different surfaces that were used in the experiments. (a) " $\mathrm{Si} / \mathrm{SiO}_{2}$ ": an oxidized silicon surface. (b) "Si-polysiloxane": a similar surface after silanization with Sigmacote ${ }^{\circledR}$. (c) "Si-PEU": a silanized silicon surface with a PEU film. (d) "Si-PEU-PC": a similar surface after modification with compound 1 , resulting in the immobilization of phosphorylcholine groups on the surface; (e) " $\mathrm{Si} / \mathrm{SiO}_{2}+\mathrm{DOPC}$ ": a DOPC bilayer formed on an oxidized silicon surface. 


\section{Experimental}

\section{Materials}

Silicon wafers were obtained from Aurel GmbH (Germany). They were cut into rectangular slides $(40 \times 7 \mathrm{~mm})$ and rubbed with Sparkleen ${ }^{\circledR}$ soap followed by rinsing with water and ethanol. Further cleaning and oxidation was performed with a $0.25 \mathrm{M}$ solution of potassium dichromate in $2.0 \mathrm{M}$ sulfuric acid at $80^{\circ} \mathrm{C}$ for $30 \mathrm{~min}$. This treatment resulted in a $\mathrm{SiO}_{2}$ layer on the silicon slides of approximately $2 \mathrm{~nm}$ thick, as estimated by ellipsometry. After rinsing with water and ethanol, clean and hydrophilic (contact angle $\cong 0^{\circ}$ ) silicon slides were obtained.

The poly(ether urethane) (PEU) foil used was Pellethane 2363-55D from Dow Chemical Inc. The foil was ultrasonically cleaned with isopropanol, water, and ethanol (15 $\mathrm{min}$ in each solvent) prior to use. Tetrahydrofuran (THF) was p.a. quality (Acros) and used as received. Human fibrinogen ( Fg) and human 2-chain high molecular weight kininogen (HMWK) were obtained from Kordia Laboratory Supplies and human serum albumin (Alb) from Sigma. Compound 1 was prepared as described before (Ch. 4). ${ }^{10}$ Sigmacote (from Sigma) is a solution of a chlorinated organopolysiloxane in heptane; it reacts quickly with hydroxyl groups on glass or silicon to form a very thin, stable, and hydrophobic layer of polysiloxane.

Phospholipid vesicles were prepared from dioleoyl phosphatidylcholine (DOPC, Avanti Polar Lipids). From a $25.4 \mathrm{mM}$ stock solution in $\mathrm{CHCl}_{3} / \mathrm{MeOH} 1: 1 \mathrm{v} / \mathrm{v}$, the calculated amount was taken and the solvent evaporated under a stream of nitrogen gas. The residue was suspended in a buffer solution (20 mM HEPES, $0.19 \mathrm{M} \mathrm{NaCl}$; $\mathrm{pH} 7.5)$ by vortexing. Sonication provided a $1.0 \mathrm{mM}$ stock solution of small unilamellar DOPC vesicles. ${ }^{\text {is }}$

\section{Polymer casting on silicon}

A $0.2 \% \mathrm{w} / \mathrm{v}$ solution of PEU in THF was prepared. The solvent contains $0.025 \%$ of the inhibitor butylated hydroxytoluene (BHT) which prevents peroxide formation. The inhibitor was not removed by distillation because a residue was observed when the distilled solvent was evaporated on a clean silicon slide. Most probably, this residue consists of polymeric peroxides formed in THF on standing or 
during evaporation. This complication was avoided when THF was used directly from the bottle (and traces of inhibitor are washed away afterwards). The silicon slides were first silanized by dipping in Sigmacote solution for $30 \mathrm{~s}$. After drying, excess Sigmacote was removed by rubbing with Sparkleen soap, followed by extensive rinsing with water. Next, the silanized silicon slides were heated on a heating plate (approximately $110^{\circ} \mathrm{C}$ ) and about $50 \mu \mathrm{L}$ of PEU solution was pipetted onto a hot silicon slide which was held tilting to one side (at an angle of about $30^{\circ}$ ). Excess solution was removed at the other end of the slide with filter paper. Evaporation of the solvent resulted in the formation of a transparent polymer film. After rinsing with ethanol and water, the thickness of the applied polymer film was estimated by ellipsometric measurements in water. The surfaces were topographically smooth in the submicron range, as observed by scanning electron microscopy.

\section{Surface modification of PEU}

A $5 \mathrm{mM}$ solution of compound 1 in isopropanol was sprayed through a nozzle with pressurized air onto the PEU-coated silicon slides ten times, while drying with a hot-air blower between sprayings. UV irradiation was performed at a distance of $40 \mathrm{~cm}$ for $20 \mathrm{~min}$ with a medium-pressure metal halide lamp (Philips HPA 400) emitting radiation mainly between 300 and $400 \mathrm{~nm}$ (radiation output measured at $1.00 \mathrm{~m}$ distance in $\mu \mathrm{W} / \mathrm{cm}^{2}$ : UV-A: 1000 ; UV-B: 320 ; UV-C: 50 ). The modified surfaces were washed with isopropanol, water, and ethanol (twice in each solvent, for $5 \mathrm{~min}$ ) to remove excess material.

\section{Surface characterization}

ESCA (Electron Spectroscopy for Chemical Analysis) was performed on the silicon slides with a Leybold MAX200 instrument using $\mathrm{Mg} \mathrm{K \alpha}(1253.6 \mathrm{eV})$ radiation at a take-off angle between the sample and the spectrometer of $90^{\circ}$. A surface area of $7 \times 4 \mathrm{~mm}^{2}$ was analyzed. Experimental details were published before. $^{8}$

Contact angles were measured using the captive-bubble technique. ${ }^{16}$ The silicon slides were placed in a cuvette filled with water and multiple air bubbles $(1 \mu \mathrm{L})$ were 
introduced through a $\mathrm{U}$-shaped needle underneath the silicon slide. The air bubbles were observed with a microscope (magnification 40x) and the height (h) and width (d) of each bubble were determined with a movable cross-hair that was connected to a micrometer. Contact angles were calculated according to the formula $\theta_{c}=\arccos$ $(2 \mathrm{~h} / \mathrm{d}-1),{ }^{16}$ a method which was preferred to the direct measurement of the contact angle with a goniometer.

\section{Protein and phospholipid adsorption}

Adsorption of proteins and phospholipid vesicles onto the silicon slides was measured using ellipsometry. The ellipsometer is employed to measure the change in the polarization state of light caused by reflection at a smooth surface. This change in polarization is strongly influenced by thin $(0.1-10 \mathrm{~nm})$ transparent films deposited on the surface. ${ }^{17} \mathrm{~A}$ description of the instrument used was published before. ${ }^{17}$ The light source was a He-Ne laser $(\lambda=632.8 \mathrm{~nm})$ and the angle of incidence at the slide in the cuvette was $68^{\circ}$, with a spot size on the sample of about $3 \times 2 \mathrm{~mm}^{2}$. The polarizer (P) and analyzer (A) angles (degrees) were adjusted under computer control with stepping motors to reach minimal light intensity in the photodetector. From the readings of $\mathrm{P}$ and $\mathrm{A}$, the refractive index and thickness of the transparent film on the surface can be calculated, which can be converted to the mass of adsorbed material on the surface. ${ }^{17-19}$ For the conditions of this study, a simplified formula could be used to calculate the adsorbed mass:

$$
\Gamma=\Delta P \cdot 0.085 \quad\left(\mu \mathrm{g} / \mathrm{cm}^{2}\right)
$$

where $\Gamma$ is the surface density of the film of adsorbed material $\left(\mu \mathrm{g} / \mathrm{cm}^{2}\right)$ and $\Delta P$ the increase of the polarizer angle (degrees) after adsorption. ${ }^{18}$

The silicon slides were placed in a trapezoidal quartz cuvette (with the cuvette walls perpendicular to the light beam) that had been silanized with Sigmacote. The cuvette was filled with $4.0 \mathrm{~mL}$ of buffer solution (20 mM HEPES, $0.19 \mathrm{M} \mathrm{NaCl}$, $3 \mathrm{mM} \mathrm{CaCl}$; $\mathrm{pH} 7.5$ ). All experiments were performed under identical stirring conditions at ambient temperature $\left(22^{\circ} \mathrm{C}\right)$. Polarizer and analyzer angles were automatically measured every $10-12 \mathrm{~s}$. After $5 \mathrm{~min}$ a protein or phospholipid vesicle stock solution was added to obtain a specified end concentration in the cuvette. When 
adsorption (of proteins or phospholipids) was completed, the solution was replaced by fresh buffer solution, while measurements continued. This was done by repeatedly ( 15 times) diluting with $4 \mathrm{~mL}$ of buffer solution and then removing $4 \mathrm{~mL}$ of the resulting solution.

\section{Results}

\section{Surface preparation}

PEU (Pellethane 2363-55D) was cast onto silanized silicon slides. The slides with the PEU films were equilibrated in water (or buffer) for at least $1 \mathrm{~h}$ before measurements were performed. The PEU films were stable in water and buffer solution for at least 7 days. Polymer layers were between 2 and $4 \mathrm{~nm}$ thick, as estimated by ellipsometry. It should be noted that PEU films also could be prepared on oxidized (hydrophilic) silicon. These films, however, were not stable in water but slowly desorbed from the silicon slide. PC groups were grafted on the PEU surface by the spraying process followed by UV irradiation.

\section{Surface characterization}

\section{ESCA}

With ESCA measurements it was verified that modification of the PEU layers indeed resulted in coupling of $\mathrm{PC}$ groups to the polymer surface. Figure $3 \mathrm{a}$ shows an ESCA overview spectrum of Si-PEU-PC. Because the polymer film is very thin, the spectrum contains, besides signals from the polymer, signals from $\mathrm{Si} / \mathrm{SiO}_{2}$ (note that ESCA scanning depth is about $10 \mathrm{~nm}$ ). This spectrum is compared with an ESCA spectrum of a PEU foil that was modified with PC groups from a previous study (Fig. 3b). ${ }^{10}$ Phosphorus signals (P 2s and P 2p) that are clearly visible in the spectrum of the foil (Fig. 3b) are obscured by silicon "plasmon" signals in the spectrum of Si-PEU-PC (Fig. 3a). 


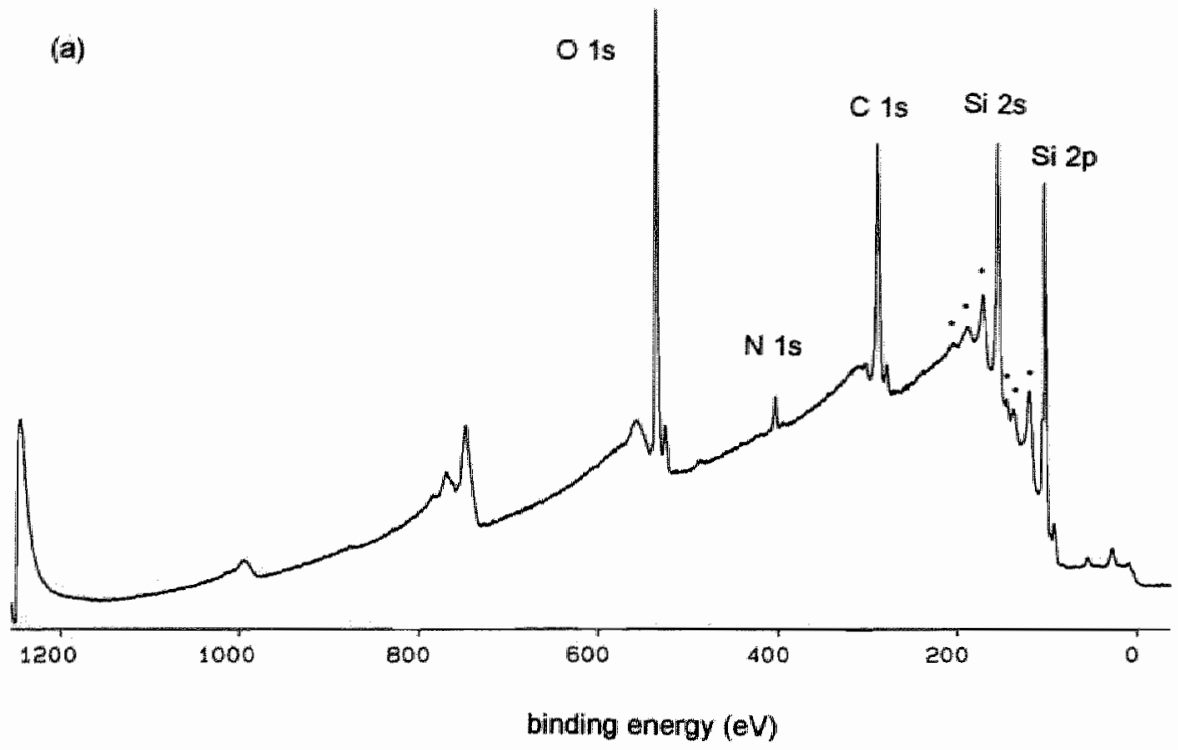

(b)

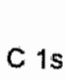

\section{0 is}

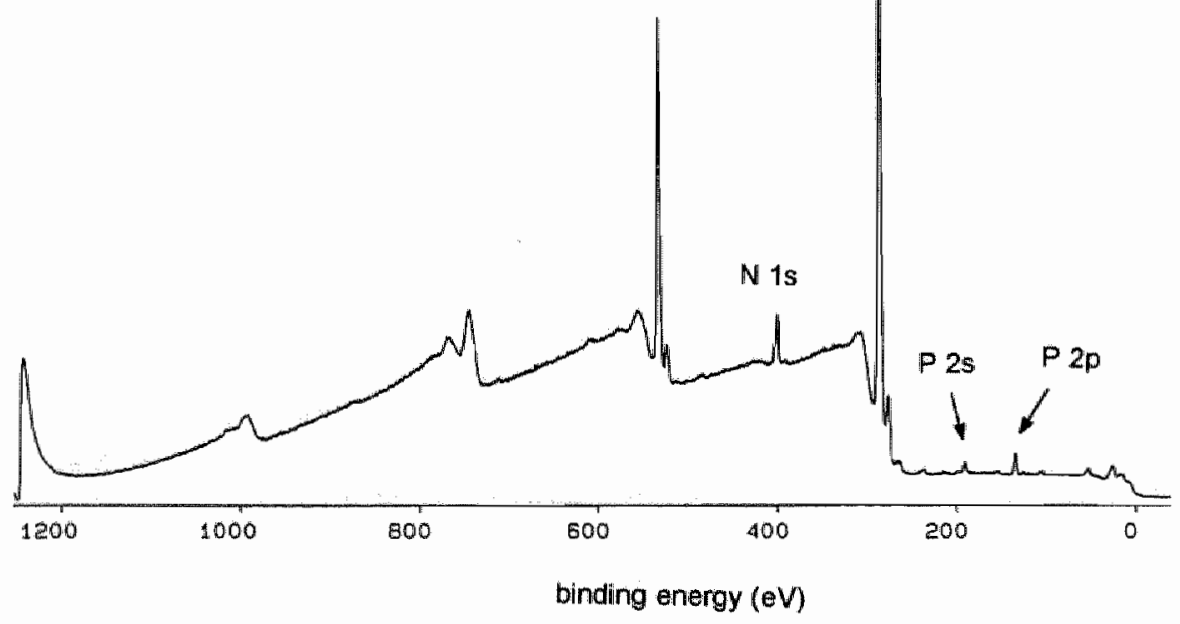

Figure 3. (a) ESCA overview spectrum of Si-PEU-PC. Since the polymer layer is very thin, signals from the polymer as well as from the (oxidized) silicon surface are observed. Note that phosphorus signals cannot be observed since they are obscured by silicon "plasmon" signals in the 100-200 eV region (indicated by a - in the spectrum). (b) Overview spectrum of a PEU foil that was modified with compound 1 (PEU-PC) from the previous research (Ch. 4) ${ }^{10}$ Note that for this sample the P $2 s$ and $\mathrm{P} 2 \mathrm{p}$ signals can be observed at 188 and $133 \mathrm{eV}$, respectively. 
(a) $N$ is

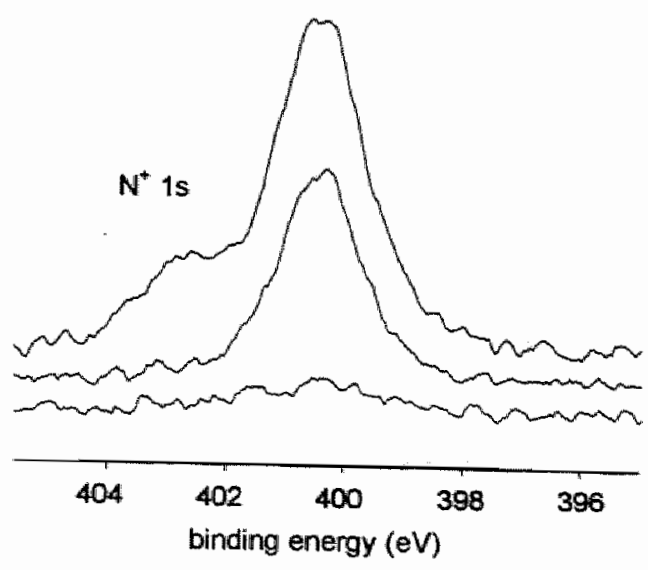

(b)

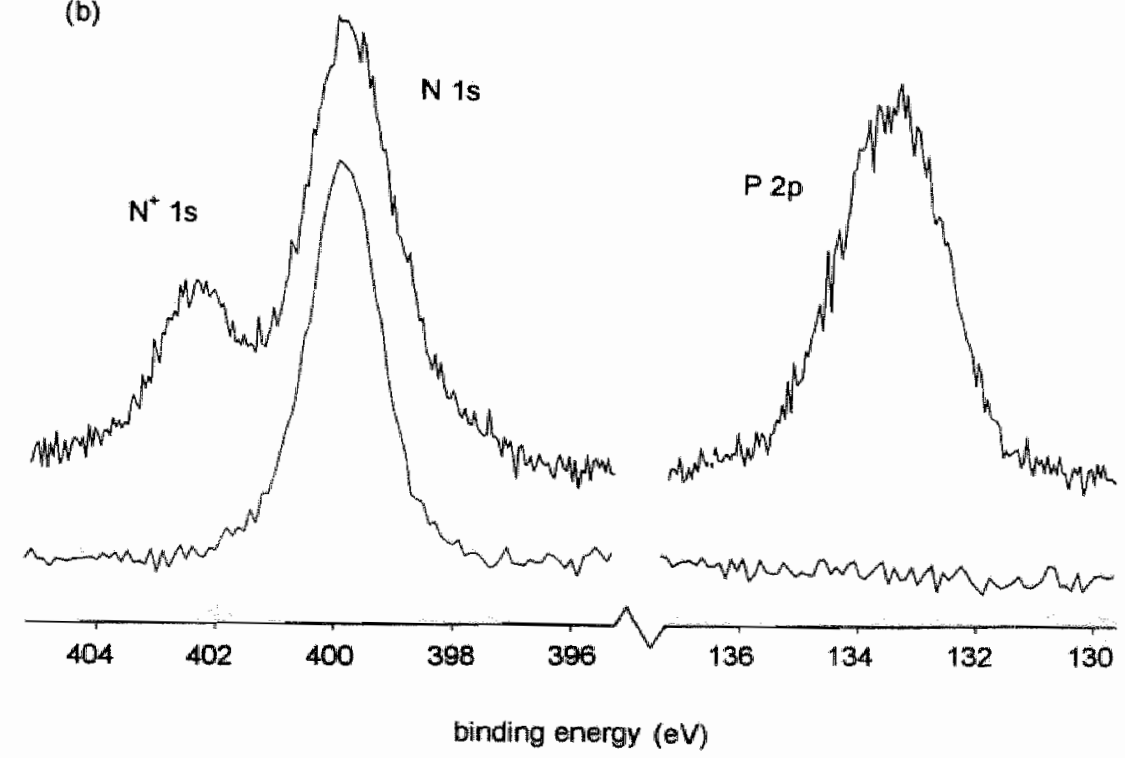

Figure 4. (a) ESCA narrow-scin $N$ 1s spectra of three different surfaces. The bottom spectrum is from an (oxidized) silicon surface (no nitrogen present); the middle spectrum is from Si-PEU and shows only one type of $\mathrm{N} 1 \mathrm{~s}$ signals; the top spectrum is from Si-PEU-PC and shows an extra peak at $402 \mathrm{eV}$ that originates from quaternary ammonium groups $\left(\mathrm{R}_{\mathrm{q}} \mathrm{N}^{+}\right)$, indicating the presence of phosphorylcholine groups. (b) Narrow-scan $\mathrm{N}$ is and $P$ 2p spectra from the previous results (Ch. 4$).{ }^{10}$ The bottom spectrum is from the PEU foil; the top spectrum is from PEU-PC and shows an $\mathrm{N}^{+} 1$ s as well as a P $2 \mathrm{p}$ signal. 
Fortunately, the presence of $\mathrm{PC}$ groups on the polymer surface also can be deduced from the presence of quaternary ammonium groups $\left(\mathrm{R}_{4} \mathrm{~N}^{+}\right)$, which is demonstrated in Figure 4. The top spectrum (Fig. 4a) shows an ESCA narrow-scan spectrum of Si-PEU-PC. The N 1s signal at $402 \mathrm{eV}$ originates from the quaternary ammonium groups $\left(\mathrm{R}_{4} \mathrm{~N}^{+}\right)$that are introduced into the surface by the PC groups. The $\mathrm{N}$ 1s signal at $400 \mathrm{eV}$, which is clearly separated from the signal at $402 \mathrm{eV}$, originates from the other $\mathrm{N}$ atoms in the material. For comparison, the narrow-scan spectra of the $\mathrm{N}$ Is and $\mathrm{P} 2 \mathrm{p}$ signals of the PEU foil that was modified with PC groups are shown in Figure $4 \mathrm{~b}$.

The narrow-scan ESCA N 1 s spectrum of Si-PEU-PC was analyzed by applying curve deconvolution, using a Gaussian line shape, as described before. ${ }^{8}$ The ratio $\mathrm{N}^{+} / \mathrm{N}^{0}$ was calculated to be $1 / 4$. As every coupled PC group introduces one positively charged and one neutral nitrogen atom (see Fig. 1), this ratio 1/4 implies that $1 / 3$ of the urethane NH groups in the PEU films was substituted by PC groups. Thus, a high degree of substitution was attained.

\section{Contact angles}

Contact angles are presented in Table 1. Hydrophilic silicon (silicon oxide surface) was fully wettable $\left(\theta_{c} \cong 0^{\circ}\right)$. Silanization with Sigmacote rendered the surface hydrophobic $\left(\theta_{c}=75^{\circ}\right)$. The PEU surface (Si-PEU) showed a contact angle of $59^{\circ}$, which decreased to $43^{\circ}$ after grafting with PC groups (Si-PEU-PC). This decrease in contact angle indicates the presence of hydrophilic groups (PC groups) on the polymer surface. For comparison, the contact angle of a DOPC bilayer on hydrophilic silicon also was measured. It should be noted that measuring the contact angle (with an air bubble) possibly disturbs the bilayer, which could affect the validity of the contact angle measurement. Interestingly, the contact angle $\left(39^{\circ}\right)$ of the DOPC bilayer is almost equal to the angle of Si-PEU-PC $\left(43^{\circ}\right)$. A contact angle of $35^{\circ}$ has been reported for a cross-linked phosphatidylcholine on a polymer surface. ${ }^{20}$ 
Table 1. Contact angles*

\begin{tabular}{ll}
\hline Surface & $\theta_{c}\left({ }^{0}\right)^{t}$ \\
\hline Si-PEU & $59(2)$ \\
Si-PEU-PC & $43(1)$ \\
Si/SiO & \\
Si-polysiloxane & $\sim 0$ \\
Si $_{\text {SiO }}+$ DOPC & $75(1)$ \\
\hline
\end{tabular}

* Contact angles were determined with the captive-bubble technique and calculated according to the formula $\theta_{c}=\arccos (2 h / d-1)$, where $h$ is the height and $d$ the diameter of the air bubble.

* Average contact angles are presented of five measurements (standard deviation in brackets).

\section{Protein and phospholipid adsorption}

The adsorption of three (human) plasma proteins (Fg, $\mathrm{Alb}$, and HMWK) was studied by ellipsometry. Figure 5 shows the adsorptions as measured for Si-PEU and Si-PEU-PC surfaces. Experiments were started by addition of protein (to the cuvette) to a final concentration of $10 \mathrm{nM}$. Adsorption of protein onto the polymer film (on the silicon slide) was continuously monitored by ellipsometry. When the adsorption approached a steady state value, the protein concentration in the cuvette was increased to $100 \mathrm{nM}$. For Fg and HMWK, this resulted in adsorption that was close to maximal adsorption, that is, further increase of the protein concentration in the solution would not result in significantly more adsorption. For Alb, the concentration in the cuvette was further increased to $1 \mu \mathrm{M}$ in order to approach maximal adsorption. Depletion of protein from the solution phase by flushing with buffer solution resulted in the desorption of only a small amount of protein from the surface (about $3 \%$ for $\mathrm{Fg}$ and $\mathrm{Alb}$, and about $7 \%$ for HMWK). Thus the majority of protein molecules adsorbed to the surface appears to be irreversibly attached. 
(a)

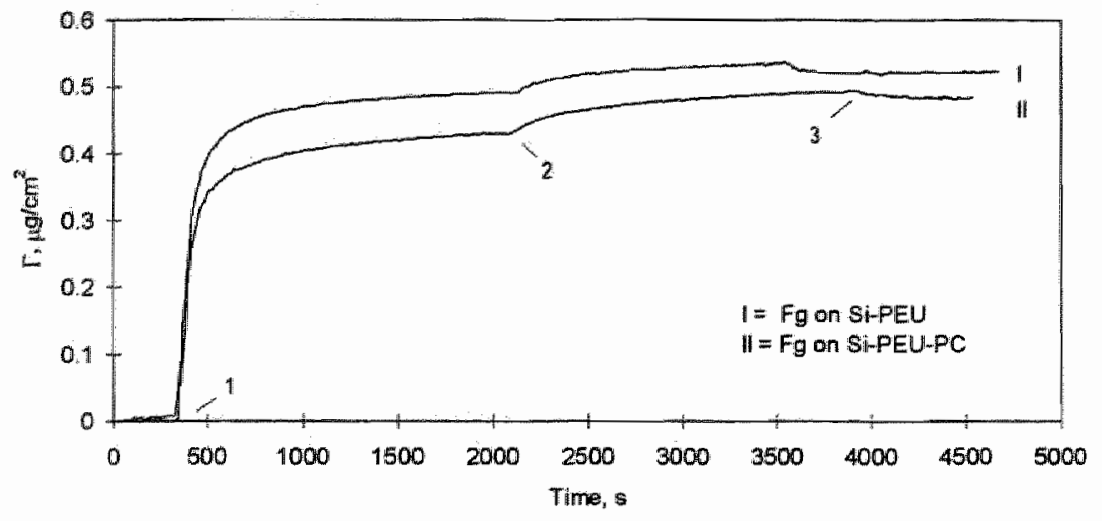

(b)

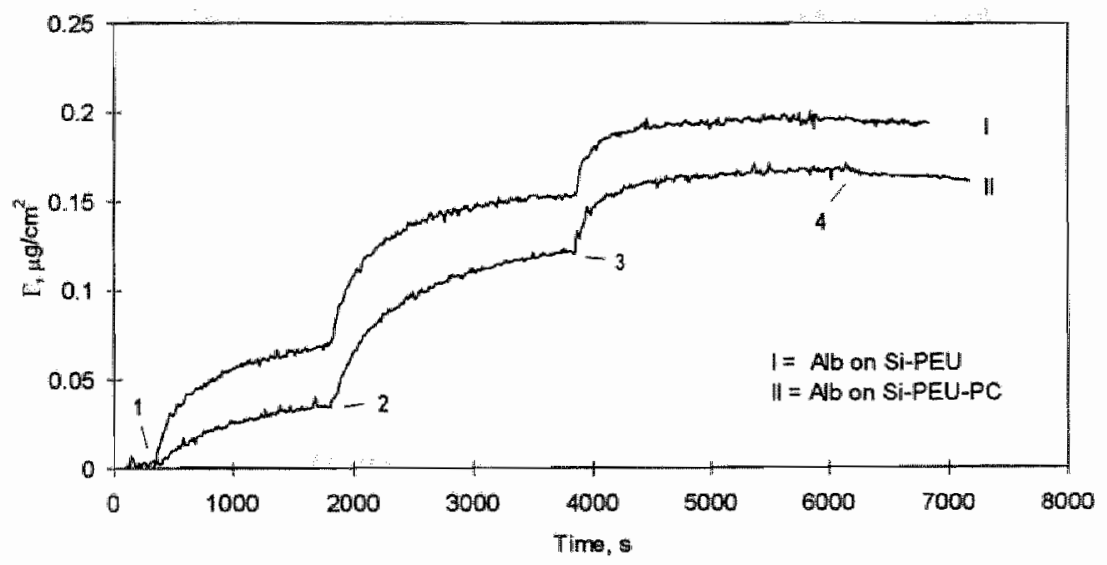

(c)

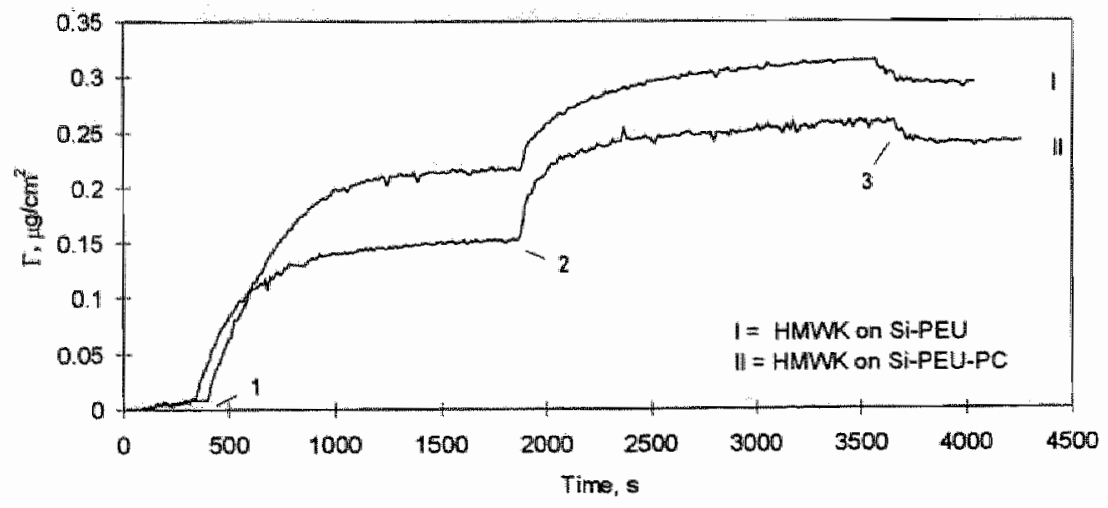


Figure 5. (previous page) Ellipsometric measurements of protein adsorption on Si-PEU and Si-PEU-PC, showing only slight differences in adsorption between the two surfaces. (a) Fg adsorption: the concentration in the cuvette was increased from 10 nM (indicated by mark 1) to $100 \mathrm{nM}(2)$; replacing the solution with fresh buffer solution (3) resulted in a minor desorption of protein from the surface (about 3\%). (b) Alb adsorption: the concentration was increased from $10 \mathrm{nM}(1)$ to $100 \mathrm{nM}(2)$ and finally to $1 \mu \mathrm{M}(3)$; replacing the solution with fresh buffer solution (4) resulted in a minor desorption (about $3 \%$ ). (c) HMWK adsorption: the concentration was increased from $10 \mathrm{nM}$ (1) to $100 \mathrm{nM}$ (2); replacement of the solution with fresh buffer solution (3) resulted in a minor desorption (about $7 \%$ ).

In Table 2 , the maximum surface density $\Gamma\left(\mu \mathrm{g} / \mathrm{cm}^{2}\right)$ of adsorbed proteins is presented. It is apparent that there is no significant difference in protein adsorption (Fg, Alb, or HMWK) between Si-PEU and Si-PEU-PC. Fg showed the highest surface density (about $0.50 \mu \mathrm{g} / \mathrm{cm}^{2}$ ), followed by HMWK (about $0.28 \mu \mathrm{g} / \mathrm{cm}^{2}$ ) and Alb (about $0.18 \mu \mathrm{g} / \mathrm{cm}^{2}$ ). For comparison, the adsorption of these proteins onto hydrophilic $\mathrm{Si} / \mathrm{SiO}_{2}$ and hydrophobic $\mathrm{Si}$-polysiloxane also was measured. $\mathrm{Fg}$ adsorption onto any of these four surfaces was similar. Alb adsorption to hydrophilic silicon was much less $\left(0.02 \mu \mathrm{g} / \mathrm{cm}^{2}\right)$ than to the other surfaces. In contrast, adsorption of HMWK to hydrophilic silicon was substantially more $\left(0.46 \mu \mathrm{g} / \mathrm{cm}^{2}\right)$ than to the other surfaces.

Table 2. Maximum surface density $(T)$ of adsorbed protein in $\mu \mathrm{g} / \mathrm{cm}^{2}$ *

\begin{tabular}{lllll}
\hline Surface & $\mathrm{Fg}$ & $\mathrm{Alb}$ & HMWK \\
\hline Si-PEU & 0.50 & 0.18 & 0.28 \\
Si-PEU-PC & 0.49 & 0.16 & 0.28 \\
Si/SiO $_{2}$ & 0.46 & 0.02 & 0.46 \\
Si-polysiloxane & 0.54 & 0.18 & 0.31 \\
Si/SiO $_{2}+$ DOPC & 0 & 0 & 0 \\
\hline
\end{tabular}

- The maximum surface coverage as estimated by a stepwise increase of the protein concentration in the cuvette. The maximum protein concentration was $0.1 \mu M$ for $F \mathrm{~g}$ and $H M W K$, and I $\mu M$ for $A l b$. Values are reported after the final washing step which caused only a minor desorption of protein (see text). Measurements were performed in duplicate and maximum standard deviations are below $15 \%$.

* Formation of the DOPC bilayer was evident from the rapid adsorption of about $0.42 \mu \mathrm{g} / \mathrm{cm}^{2}$ on the surface from a $20 \mu \mathrm{M}$ solution of DOPC vesicles. 
These results were compared with the protein adsorption onto a DOPC bilayer formed on hydrophilic silicon. The bilayer was rapidly formed when the silicon slide was immersed into a (stirred) solution of DOPC vesicles $(20 \mu \mathrm{M})$. The mass of the DOPC layer deposited in this way amounted to $0.42 \mu \mathrm{g} / \mathrm{cm}^{2}$, which is similar to the mass of a phospholipid billayer as created in a Langmuir-Blodgett trough. ${ }^{21}$ The adsorption of any of the proteins ( $\mathrm{Fg}, \mathrm{Alb}$, or HMWK) on the DOPC bilayer remained below the detection limit of ellipsometry (Table 2).

Next, the adsorption of DOPC vesicles onto the polymer surfaces was investigated and the possible effect of pre-adsorbed DOPC on the adsorption of proteins. A $20 \mu \mathrm{M}$ DOPC vesicle solution was used for the adsorption experiments since this concentration was sufficient to quickly create a DOPC bilayer on hydrophilic silicon (cf. above). The adsorbed amount of DOPC was similar for Si-PEU and Si-PEU-PC: about $0.06 \mu \mathrm{g} / \mathrm{cm}^{2}$. This amounts to about $30 \%$ of monolayer coverage (which would be about $0.21 \mu \mathrm{g} / \mathrm{cm}^{2}$ ). Protein adsorption onto the Si-PEU and Si-PEU-PC surfaces that were pre-treated with DOPC was significantly reduced compared to the corresponding surfaces without pre-adsorbed DOPC present (Table 3). For Si-PEU, Fg adsorption was reduced by $50 \%$, Alb adsorption by $90 \%$, and HMWK adsorption by $80 \%$. The reduction in protein adsorption was slightly less pronounced for Si-PEU-PC: $30 \%$ for $\mathrm{Fg}, 75 \%$ for $\mathrm{Alb}$, and $55 \%$ for HMWK.

Table 3. Maximum surface density ( $\Gamma$ ) of adsorbed protein in $\mu \mathrm{g} / \mathrm{cm}^{2}$, on surfaces pre-treated with DOPC vesicles."

\begin{tabular}{llll}
\hline Surface & Fg & Alb & HMWK \\
\hline Si-PEU & 0.24 & 0.02 & 0.05 \\
Si-PEU-PC & 0.34 & 0.04 & 0.13 \\
\hline
\end{tabular}

" DOPC was adsorbed first, followed by protein. The concentration of DOPC vesicles in the cuvette was $20 \mu \mathrm{M}$ in each case. The amount of adsorbed DOPC was approximately $0.06 \mu \mathrm{g} / \mathrm{cm}^{2}$ on each surface. The maximum protein concentration in the cuvette was $0.1 \mu M$ for $F g, 0.5 \mu M$ for $A l b$, and $0.05 \mu M$ for $H M W K$. 


\section{Discussion}

The outer membrane leaflet of intact blood cells mainly consists of phosphorylcholine-containing phospholipids, such as phosphatidylcholine and sphingomyelin, which provide a non-thrombogenic surface. Only upon damage or activation do other phospholipids appear in the outer membrane leaflet, transforming it into a thrombogenic surface. ${ }^{22}$

These observations led to the idea of using synthetic phospholipids containing phosphatidylcholine for the surface modification of blood-contacting devices, in order to make them more blood compatible. ${ }^{23}$ The introduction of diacetylene ${ }^{23}$ or methacryloyl ${ }^{20}$ groups in the acyl chains made it possible to stabilize the adsorbed phospholipids by cross-linking. Very recently, phospholipids that can be coupled covalently to a polymer surface through one of their acyl chains were synthesized. ${ }^{24}$

Another approach was introduced by Hayward et al. ${ }^{\text {II }}$ They suggested that the phosphorylcholine headgroup is responsible for blood compatibility and not the whole phosphatidylcholine molecule. Therefore, methods were developed to couple PC groups to a material's surface ${ }^{12}$ or to incorporate them in monomers. ${ }^{25}$ In several studies it was shown that the immobilized PC groups improved the blood compatibility of the material by decreasing protein and/or platelet adsorption. ${ }^{12,13,24,26}$ In line with these results it was demonstrated in this laboratory that surface modification of PEU with PC-containing aryl azides decreases platelet adsorption/activation and thrombin generation at the material's surface (Ch. 4). ${ }^{10}$

In the present work, the protein adsorption onto PEU surfaces modified with PC groups was studied. For this purpose, thin PEU films were deposited onto (silanized) silicon slides so that they could be studied by ellipsometry. PC groups were covalently bound to these surfaces, as verified by ESCA and contact angle measurements. Ellipsometric measurements showed no significant difference in protein (Fg, Alb, and HMWK) adsorption between Si-PEU-PC and Si-PEU. The amounts of adsorbed proteins roughly indicate monolayer coverage. Values for adsorbed Fg (about $0.50 \mu \mathrm{g} / \mathrm{cm}^{2}$ ) and Alb (about $0.18 \mu \mathrm{g} / \mathrm{cm}^{2}$ ) lie between "side-on" and "end-on" adsorption of the corresponding (though bovine) proteins in monolayers, as found in the literature (for a compilation of data, see Ref. 27).

It is interesting to compare the results of the adsorption of proteins to a polyurethane surface (Si-PEU) with adsorption data of $\mathrm{Fg}$ (bovine) and Alb (bovine) 
on poly(vinyl chloride) (PVC). An ellipsometric study of the protein adsorption on PVC showed a maximum surface density of $0.54 \mu \mathrm{g} / \mathrm{cm}^{2}$ for $\mathrm{Fg}$ and $0.17 \mu \mathrm{g} / \mathrm{cm}^{2}$ for $A l b,{ }^{27}$ values that come close to the values presented here for PEU.

DOPC bilayers formed on hydrophilic silicon demonstrated a completely different behavior with respect to protein adsorption. The experiments described here showed that none of the proteins adsorbed to these surfaces. Apparently, the ordered structure and tight packing of the PC headgroups, caused by the self-assembly of the phospholipid bilayer, constitutes an obstacle for protein adsorption that is lacking for a PEU surface with randomly coupled PC groups.

Next, the effect of pre-incubation of the polymer surfaces with phospholipid vesicles (DOPC) on protein adsorption was studied. The idea originated from earlier reports that polymers containing PC groups can have an enhanced affinity (compared to the corresponding polymer without PC groups) for phospholipids from blood and that they would even get organized on the surface as a "biomembrane-like" structure..$^{28}$ It was reported that the adisorption of DPPC (dipalmitoyl phosphatidylcholine) vesicles was slightly higher on PC-containing polymers than on the corresponding polymers without PC groups. ${ }^{28,29}$ After adsorption of DPPC, both polymers were found to adsorb substantially fewer platelets. The decrease in platelet adsorption was more pronounced for the PC-containing polymers than for the polymers without PC groups. ${ }^{29}$ Also protein adsorption was found to decrease after treatment of polymers with DPPC vesicles. ${ }^{30}$ Adsorption of Alb, for example, was reduced by circa $50 \%$ after treatment of poly(butyl methacrylate) with DPPC. About the same reduction in Alb adsorption was reported for a PC-containing polymer after treatment with DPPC. ${ }^{30}$

In the present report it was found that small amounts of DOPC (about $0.06 \mu \mathrm{g} / \mathrm{cm}^{2}$ ) adisorbed onto the PEU surfaces but no significant differences were found between Si-PEU-PC and Si-PEU. Although the surface density of adherent DOPC molecules was much less than the surface density of a monolayer, subsequent protein adsorption was substantially diminished for both surfaces (slightly less pronounced for Si-PEU-PC) and especially Alb adsorption was much less on pretreated PEU than on PEU that had not been pre-treated with DOPC vesicles. A definite explanation for the fact that such small amounts of adsorbed DOPC can diminish protein adsorption to such an extent is lacking, although one could 
speculate that hydrophobic patches on the surface were covered by adsorbed DOPC molecules, which could decrease protein denaturation on the surface.

These results confirm the findings of Ueda et al. ${ }^{30}$ that PC-containing phospholipids adsorbed to polymer surfaces reduce protein adsorption. In the current report however, it was not found that more phospholipids adsorbed to a polymer with PC groups bound to the surface.

In conclusion, adsorption of $\mathrm{Fg}, \mathrm{Alb}$, and HMWK onto a poly(ether urethane) surface modified with phosphorylcholine groups resembled adsorption onto unmodified polymer. Also, the adsorption of DOPC vesicles was similar for PCmodified PEU and unmodified PEU surfaces. An interesting result was that a small amount of adherent DOPC molecules (much less than a monolayer) diminished protein adsorption considerably. It seems that the presence of covalently bound phosphorylcholine groups on a polymer surface is insufficient to prevent protein adsorption. In contrast, none of the proteins adsorbed to a DOPC bilayer (formed on hydrophilic silicon). Although it is possible that high concentrations of phosphorylcholine groups on certain polymers can reduce protein adsorption, only a self-assembled phospholipid bilayer can suppress protein adsorption effectively. In this respect, the approach by which diacyl phosphatidylcholine molecules are coupled to a polymer surface through one of their acyl chains looks promising, since hydrophobic interactions between the free acyl chains could result in a more highly ordered structure. ${ }^{24}$ It can be concluded from this and the previous study (Ch. 4$)^{10}$ that the blood compatibility of poly(ether urethane) modified with phosphorylcholine groups at the surface is improved due to a decrease in platelet adsorption/activation and not due to a decrease in protein adsorption. It cannot be excluded, however, that the complex interaction between plasma proteins and the surface of PC-modified PEU can lead to a decrease of the adsorption of one or more proteins. 


\section{References}

1. M.D. Lelah and S.L. Cooper, Polyurethanes in Medicine, CRC Press, Boca Raton, Florida, 1986.

2. A.S. Hoffman, "Modification of material surfaces to affect how they interact with blood," Ann. N.Y. Acad. Sci., 516, 96-101 (1987).

3. J.D. Andrade, in Surface and interfacial aspects of biomedical polymers. Vol. 2. Protein Adsorption, J.D. Andrade (ed.), Plenum Press, New York, 1985, Chap. 1.

4. R.E. Baier, "Selected methods of investigation for blood-contact surfaces," Ann. N.Y. Acad. Sci., 516, 68-77 (1987).

5. T. Sugawara and T. Matsuda, "Synthesis of phenylazido-derivatized substances and photochemical surface modification to immobilize functional groups" "J. Biomed. Mater. Res., 32, 157-164 (1996).

6. Y.-C. Tseng and K. Park, "Synthesis of photoreactive poly(ethylene glycol) and its application to the prevention of surface-induced platelet activation," J. Biomed. Mater. Res., 26, 373-391 (1992).

7. Y.B.J. Aldenhoff and L.H. Koole, "Studies on a new strategy for surface modification of polymeric biomaterials," J. Biomed. Mater. Res., 29, 917-928 (1995).

8. J.M.H. Kuijpens, G.A. Kardaun, A.P. Pijpers, and L.H. Koole, "Immobilization of theophylline on medical-grade polyurethane inhibits surface-induced activation of blood platelets," J. Am. Chem. Soc., 117, 8691-8697 (1995).

9. A.P. van der Heiden and L.H. Koole, "Photochemical coupling of aryl azides to poly(ether urethane) surfaces: studies with a fluorescent model compound," Macromolecules, 29, 7012-7015 (1996).

10. A.P. van der Heiden, D. Goebbels, A.P. Pijpers, and L.H. Koole, "A photochemical method for the surface modification of poly(ether urethanes) with phosphorylcholinecontaining compounds to improve hemocompatibility," J. Biomed. Mater. Res., 37, 282-290 (1997).

11. J.A. Hayward and D. Chapman, "Biomembrane surfaces as models for polymer design: the potential for haemocompatibility," Biomaterials, 5, 135-142 (1984).

12. D. Chapman, "Biomembranes and new hemocompatible materials," Langmuir, 9, 3945 (1993).

13. K. Ishihara, N.P. Ziats, B.P. Tierney, N. Nakabayashi, and J.M. Anderson, "Protein adsorption from human plasma is reduced on phospholipid polymers, ${ }^{n} J$. Biomed. Mater. Res., 25, 1397-1407 (1991).

14. T. Lindhout, R. Blezer "C. Maassen, V. Heijnen, and C.P.M. Reutelingsperger, "Platelet procoagulant surface as an essential parameter for the in vitro evaluation of the blood compatibility of polymers," J. Mater. Sci. Mater. Med., 6, 367-372 (1995).

15. J. Rosing, G. Tans, J.W.P. Govers-Riemslag, R.F.A. Zwaal, and H.C. Hemker, "The role of phospholipids and factor Va in the prothrombinase complex," J. Biol. Chem., $255,274-283$ (1980).

16. J.D. Andrade, L.M. Smith, and D.E. Gregonis, in Surface and interfacial aspects of biomedical polymers. Vol. 1 . Surface chemistry and physics, J.D. Andrade (ed.), Plenum Press, New York, 1985, Chap. 7. 
17. P.A. Cuypers, J.W. Corsel, M.P. Janssen, M.M.M. Kop, W.Th. Hermens, and H.C. Hemker, "The adsorption of prothrombin to phosphatidylserine multilayers quantitated by ellipsometry," J. Biol. Chem., 258, 2426-2431 (1983).

18. G.M. Willems, P.L.A. Giesen, and W.Th. Hermens, "Adsorption and conversion of prothrombin on a rotating disc," Blood, 82, 497-504 (1993).

19. R.M.A. Azzam and N.M. Bashara, Ellipsometry and Polarized Light, Elsevier Science Publishers, Amsterdam, 1987.

20. S.L. Regen, P. Kirszensztejn, and A. Singh, "Polymer-supported membranes. A new approach for modifying polymer surfaces," Macromolecules, 16, 335-338 (1983).

21. P.L.A. Giesen, G.M. Willems, and W.Th. Hermens, "Production of thrombin by the prothrombinase complex is regulated by membrane-mediated transport of prothrombin," J. Biol. Chem., 266, 1379-1382 (1991)..

22. E.M. Bevers, P. Comfurius, J.L.M.L. van Rijn, and R.F.A. Zwaal, "Generation of prothrombin-converting activity and the exposure of phosphatidylserine at the outer surface of platelets, ${ }^{\prime \prime}$ Eur. J. Biochem., 122, 429-436 (1982).

23. O. Albrecht, D.S. Johnston, C. Villaverde, and D. Chapman, "Stable biomembrane surfaces formed by phospholipid polymers," Biochim. Biophys. Acta, 687, 165-169 (1982).

24. A.S. Köhler, P.J. Parks, D.L. Mooradian, G.H.R. Rao, and L.T. Furcht, "Platelet adhesion to novel phospholipid materials: Modified phosphatidylcholine covalently immobilized to silica, polypropylene, and PTFE materials," J. Biomed. Mater. Res., 32, 237-242 (1996).

25. K. Ishihara, T. Ueda, and N. Nakabayashi, "Preparation of phospholipid polymers and their properties as polymer hydrogel membranes," Polym. J, 22, 355-360 (1990).

26. K. Ishihara, S. Tanaka, N. Furukawa, K. Kurita, and N. Nakabayashi, "Improved blood compatibility of segmented polyurethanes by polymeric additives having phospholipid polar groups. I. Molecular design of polymeric additives and their functions," J. Biomed. Mater. Res , 32, 391-399 (1996).

27. C.-G. Gölander and E. Kiss, "Protein adsorption on functionalized and ESCAcharacterized polymer films studied by ellipsometry," J. Colloid Interface Sci., 121, 240-253 (1988).

28. M. Kojima, K. Ishihara, A. Watanabe, and N. Nakabayashi, "Interaction between phospholipids and biocompatible polymers containing a phosphorylcholine moiety," Biomaterials, 12, 121-124 (1991).

29. K. Ishihara, H. Oshida, Y. Endo, A. Watanabe, T. Ueda, and N. Nakabayashi, "Effects of phospholipid adsorption on nonthrombogenicity of polymer with phospholipid polar group," J. Biomed. Mater. Res., 27, 1309-1314 (1993).

30. T. Ueda, A. Watanabe, K. Ishihara, and N. Nakabayashi, "Protein adsorption on biomedical polymers with a phosphorylcholine moiety adsorbed with phospholipid, $" J$. Biomater. Sci. Polym. Edn., 3, 185-194 (1991). 


\section{General Discussion}

The design of hemocompatible materials has turned out to be extremely difficult, as was nicely stated in a recent article by Ramer ${ }^{1}$ who even spoke of the "blood compatibility catastrophe." But also back in 1981 Andrade et al. ${ }^{2}$ described the history of research on blood-material interactions as "frustrative." There is no widely accepted definition of hemocompatibility ${ }^{l}$ although certain characteristics of blood compatible materials were proposed (section 1.3). No standardized hemocompatibility tests exist and no material can be called truly "hemocompatible". ${ }^{1}$ Why is it so difficult to design a hemocompatible material? Most importantly, an artificial material can never be as dynamic as the lining of endothelial cells of natural vessels. The endothelium provides a renewable smooth surface with several components that passively and actively control blood clotting (section 1.2). The surface of an artificial vessel will rapidly become covered by proteins after which blood platelets will adhere to the protein film. The composition of the protein film and the degree of denaturation probably determines the reaction of platelets. The presence of adsorbed factor XII and HMWK will lead to contact activation, eventually resulting in fibrin formation.

A logical approach to design a hemocompatible material would be to cover a polymeric surface with a lining of endothelial cells. It was demonstrated that endothelial cells can be grown on polymeric surfaces (teflon and polyurethane) and form a confluent monolayer (assisted by pre-adsorbed fibronectin) but the patency of the modified synthetic grafts in vivo (sheep) was not improved, probably due to the (observed) loss of endothelial cells and the inability of seeded cells to inhibit thrombus formation. ${ }^{3}$ Also low density endothelial cell seeding on synthetic grafts implanted in humans failed to improve perfornance. ${ }^{4}$

Several other methods exist for the surface modification of polymeric materials, a few of which were briefly described in section 1.3 . Often, a polyurethane is chosen as the base material for blood contacting devices (vascular grafts, heart valves) since it has excellent mechanical properties and relatively good hemocompatibility 
compared to other polymers. Improved surface modification methods are needed to prepare a polyurethane surface suitable for the production of small-diameter vascular grafts.

The approach to improve the hemocompatibility of polyurethanes followed in this study consisted of the surface modification with phosphorylcholine groups. The idea was based on the observation that phospholipids (in bilayers and vesicles) containing phosphorylcholine are non-thrombogenic (section 1.3). Since it was demonstrated that also phosphorylcholine incorporated in other molecules has nonthrombogenic properties, a relatively facile surface modification method was developed that can be used to attach phosphorylcholine groups to a polyurethane surface.

The photochemically activatable aryl azides that were synthesized permit the rapid surface modification of a polyurethane surface. Although the photochemistry of aryl azides is only partly understood, the value of these very reactive compounds is well-recognized. In solution, UV irradiation of these compounds leads to a complex mixture of products. Immobilized on a surface however, reactions are more selective and possible by-products are easily washed away. It was demonstrated that aryl azides can be prepared with phosphorylcholine endgroups and that these compounds can be attached to a polyurethane (Pellethane) surface (Ch. 2 and 4). Although several chemical methods exist to couple compounds to a polymer surface, the photochemical method presented in this study is fast and does not use toxic or harmful substances. Furthermore, since aryl azides are sometimes even capable of reacting with normally unreactive polymers such as polyethylene and teflom the method can be extended (with some modifications) to modify all kinds of polymers.

Surface analysis of polymers is not an easy task. Most importantly, great care must be taken to ensure that the polymer surface is not contaminated by compounds from the environment since a surface is rapidly covered resulting in a surface with different properties. In this study contact angles were measured to determine the hydrophilicity of the prepared surfaces. Although the method is fast and very surface sensitive results are difficult to compare with results from other research groups since many factors influence the measurements (equilibrium swelling, surface contamination, method of measurement). Therefore, contact angle measurements are normally used to check if surface modification has resulted in changed hydrophilicity. Results of this study (Ch. 4) indicated that polyurethane with attached 
phosphorylcholine groups (coupled via a spacer chain) has a decreased contact angle, as would be expected. However, the contact angle was not as much decreased as would be expected for a completely covered surface although predictions are difficult to make and results from the literature are sometimes contradictory.

Surface analysis by ESCA (electron spectroscopy for chemical analysis) was essential to show that the modified polyurethane indeed contained phosphorylcholine groups at the surface. ESCA analysis was facilitated by the fact that phosphorylcholine contains phosphate and quaternary ammonium groups which can unequivocally be detected on a polyurethane surface (Ch. 4).

The hemocompatibility of the prepared surfaces can be investigated with various techniques. As was stated above no standardized techniques exist but several methods are likely to give a reasonable indication of the hemocompatibility of a material. It is important to use a combination of methods to get a reliable indication of how a material will influence blood. Several in vitro techniques were employed to measure blood compatibility (Ch. 4 and 5). Thrombin generation tests were used to measure the degree of contact activation caused by the polymer. Clotting times of the polyurethane surfaces modified with phosphorylcholine groups were clearly prolonged, depending on the amount present at the surface. Platelet adhesion was studied by SEM (scanning electron microscopy) which is a widely used method to investigate hemocompatibility of materials. The interpretation of platelet adhesion experiments has been the subject of much debate. The degree of activation, as shown by spreading and pseudopod formation, is now considered more important than the number of adhered platelets. Whereas the thrombin generation tests showed considerable differences between all surfaces (e.g. depending on the surface concentration of phosphorylcholine groups) platelet adhesion tests only showed clear differences between unmodified and modified polymer.

Protein adsorption on an artificial surface probably determines the blood compatibility of a device to a major extent since it occurs immediately after blood contact and results in a fully covered surface on which platelets will then adhere (section 1.3). The measurement of protein adsorption from blood is complicated since many proteins are present in plasma which can displace each other from the surface. Therefore, most protein adsorption experiments are carried out with only one or a few proteins present in a buffer solution. Single protein adsorption experiments were performed on polyurethane (deposited on silicon wafers) using 
ellipsometry to measure protein adsorption (Alb, Fg, and HMWK) in buffer solution as a function of time (Ch. 5). Ellipsometry provides data that can be used to determine the thickness of an adsorbed protein layer from which the adsorbed mass can then be estimated. It was found that surface modification with phosphorylcholine groups had little influence on protein adsorption, in contrast to some literature reports. On the other hand, pre-adsorption of DOPC (from vesicles) on the polyurethane surfaces diminished protein adsorption on all surfaces. Protein adsorption on DOPC bilayers formed on hydrophilic silicon was absent. It seems that phosphorylcholine groups can diminish protein adsorption considerably but only if the surface density is high and the groups are tightly packed.

In conclusion, it seems that the hemocompatibility of polyurethane (Pellethane) modified with phosphorylcholine groups improves due to a decrease in platelet adsorption/activation and diminished contact activation. As was stated before, these phenomena are dependent on the initial protein adsorption. From the single protein adsorption experiments however, no influence was found of the surface modification of the polymer (with phosphorylcholine groups) on protein adsorption. Protein adsorption experiments using mixtures of several major plasma proteins could lead to a different conclusion.

\section{References}

1. B.D. Ratner, "The blood compatibility catastrophe," J. Biomed. Mater. Res., 27, 283-287 (1993).

2. J.D. Andrade, D.L. Coleman, P. Didisheim, S.R. Hanson, R. Mason, and E.W. Merrill, "Blood-materials interactions -20 years of frustration," Trans. Am. Soc. Arif. Int. Organs, 27, 659-662 (1981).

3. L.A. Poole-Warren, K. Schindhelm, A.R. Graham, P.R. Slowiaczek, and K.R. Noble, "Performance of small diameter synthetic vascular prostheses with confluent autologous endothelial cell linings," $J$. Biomed. Mater. Res., 30, 221-229 (1996).

4. M. Herring, J. Smith, M. Dalsing, J. Glover, R. Compton, K. Etchberger, and T. Zollinger, "Endothelial seeding of polytetrafluoroethylene femoral popliteal bypasses: The failure of low-density seeding to improve patency," J. Vasc. Surg., 20, 650-655 (1994). 


\section{Summary}

Artificial vascular grafts and heart valves are of great importance in cardiovascular surgery. Although healthy veins from the body (especially from the legs) are often used to replace diseased coronary arteries, removal of those veins often causes lasting discomfort to the patient. Furthermore, the diameter does not always match that of the artery to be replaced. The use of animal (porcine) valves to replace human heart valves has the disadvantage that they have to be replaced after about seven years because of calcification. A major disadvantage of the use of artificial vascular grafts and heart valves is that thrombosis can occur which can lead to occlusion of vessels. Therefore, continuous anti-coagulation therapy is necessary, which can cause bleeding problems. Thrombosis occurs since the natural lining of endothelial cells, which is essential in regulating blood clotting, is absent.

Much research has been done to find materials that minimize surface-induced thrombotic reactions. Polyurethanes are a promising class of materials for the preparation of artificial vascular grafts and heart valves. These polymers have excellent mechanical properties and relatively good hemocompatibility, compared to other polymers. In order to improve the blood compatibility of these and other polymers many surface modification methods have been developed. Classical methods include the use of heparin and poly(ethylene glycol) which can be attached to the surface of a polymeric material in various ways. A new and promising method uses phosphorylcholine groups that can be incorporated in the polymer chain (as a side group) or attached to the surface. The idea originates from the observation that phospholipid vesicles containing phosphorylcholine are non-thrombogenic (in contrast to phospholipids containing phosphorylserine). Since phosphorylcholine is the hydrophilic endgroup that interfaces with blood and since it was shown that also phosphorylcholine incorporated in other molecules has non-thrombogenic properties, interest in surface modification methods that can couple phosphorylcholine groups to a polymer surface is growing.

This study describes a new method to couple phosphorylcholine groups covalently to a polyurethane (Pellethane) surface with the aim of improving the hemocompatibility of the material. 
Chapter 2 describes the synthesis of several compounds that can be used to attach phosphorylcholine groups to a polymer surface. The compounds consist of a photoreactive group (an azidophenyl moiety) and a phosphorylcholine group that are separated by a variable-length spacer chain consisting of ethylene glycol units. The photoreactive azidophenyl group is very stable until UV irradiation turns it into a very reactive group capable of reacting with weakly nucleophilic groups at a polymer surface. The synthetic schemes presented here allow for the rapid and safe preparation of phosphorylcholine-containing aryl azides.

Chapter 3 presents proof that aryl azides can indeed couple covalently to a polyurethane (Pellethane 2363-55D) surface. For this purpose an aryl azide was synthesized carrying a fluorescent dimethylaminonaphthalenesulfonyl (dansyl) moiety. Spraying with a solution of this compound followed by irradiation with UV light resulted in the covalent coupling to a polyurethane surface which could be proven by a rapid hydrolysis experiment. It was further found that a surface density of about $25 \mathrm{nmol} / \mathrm{cm}^{2}$ could be reached by this surface modification method. It was suggested that this high surface density could be due to the surface roughness of the polymer (resulting in an increased surface area) and (minor) equilibrium swelling which causes modification of the polymer to a certain depth.

In Chapter 4 two phosphorylcholine-containing aryl azides are presented that were used for the surface modification of a polyurethane (Pellethane) to improve hemocompatibility. After the photochemical surface modification (comparable to the procedure described in $\mathrm{Ch} .3$ ) the surfaces were analyzed with contact angle measurements which showed decreased contact angles for all modified surfaces, as would be expected for surfaces modified with relatively hydrophillic phosphorylcholine groups. ESCA (Electron Spectroscopy for Chemical Analysis) measurements showed that the composition of the surface had changed and that phosphorylcholine groups were now present at the polyurethane surface (analyzed depth about $50 \AA$ ). In vitro hemocompatibility was determined with thrombin generation assays and platelet adhesion studies (using platelet-rich plasma). The thrombin generation tests showed that clotting times of the polyurethane surfaces modified with phosphorylcholine groups were clearly prolonged, depending on the amount of phosphorylcholine present at the surface. Platelet adhesion studies with scanning electron microscopy demonstrated that fewer platelets (showing less 
activation) adhered to the modified surfaces than to the unmodified polyurethane. Hence, these tests indicate an improved hemocompatibility for the modified surfaces.

Chapter 5 describes single protein adsorption experiments on modified polyurethane surfaces. Since ellipsometry is one of the few techniques that can measure protein adsorption continuously and in situ this method was selected for the experiments. For this purpose, thin polyurethane films were prepared on silicon wafers after which phosphorylcholine groups were introduced by the method described in Chapter 4. Adsorption was measured of the following human proteins: albumin (Alb), fibrinogen (Fg), and high molecular weight kininogen (HMWK) (the importance of these proteins in thrombosis was outlined in Ch. 1). It was shown that the presence of phosphorylcholine groups at the surface had little effect on the adsorption of the proteins, against expectations. In contrast, pre-treatment of the surfaces with a suspension of dioleoylphosphatidylcholine (DOPC) vesicles diminished protein adsorption on all surfaces. On a DOPC bilayer formed on silicon protein adsorption was absent, as anticipated. These results show that the mere presence of phosphorylcholine groups at a polyurethane surface is insufficient to suppress protein adsorption (at least in single protein adsorption experiments); only an ordered and tightly packed layer of phosphorylcholine-containing molecules can probably suppress protein adsorption effectively.

In Chapter 6 the results of this study are discussed and some of the difficulties of designing and testing a new "hemocompatible" material are presented. 


\section{Samenvatting}

Synthetische bloedvaten en hartkleppen zijn van groot belang in de cardiovasculaire chirurgie. Hoewel gezonde aderen uit het lichaam (in het bijzonder die uit de benen) vaak gebruikt worden om aangetaste kransslagaderen te vervangen kleven er enkele nadelen aan het gebruik van deze aderen. De verwijdering van aderen uit het been kan leiden tot langdurige klachten bij de patiënt en bovendien wijkt de diameter soms te veel af van die van de te vervangen kransslagader. Het gebruik van dierlijke kleppen (van varkens) orn de hartkleppen van een patiënt te vervangen heeft onder andere als nadeel dat ze na circa zeven jaar vervangen moeten worden wegens verkalking. Een belangrijk nadeel van het gebruik van synthetische bloedvaten en hartkleppen is dat trombose kan optreden waardoor vaten verstopt kunnen raken. Daarom moeten continu anti-coagulatie medicijnen gebruikt worden wat kan leiden tot inwendige bloedingen. Trombose treedt op doordat de natuurlijke endotheellaag afwezig is waardoor de regulatie van de bloedstolling verstoord wordt.

Er wordt yeel onderzoek gedaan om materialen te vinden die zo min mogelijk oppervlakte-geïnduceerde trombotische reacties veroorzaken. Polyurethanen vormen een veelbelovende klasse van materialen voor de vervaardiging van synthetische bloedvaten en hartkleppen. Deze polymeren bezitten zeer goede mechanische eigenschappen en een relatief goede bloedcompatibiliteit, vergeleken met andere polymeren. Om de bloedcompatibiliteit van deze en andere polymeren te verbeteren zijn vele oppervlaktemodificatie-methoden ontwikkeld. Van oudsher worden vaak heparine en poly(ethyleen glycol) gehecht aan polymeren. Een nieuwe en veelbelovende methode maakt gebruik van fosforylcholine-groepen die aangebracht kunnen zijn in de polymeerketen (als zijgroep) of aan het oppervlak. Het idee is ontstaan vanuit de waameming dat fosfolipide vesicles die fosforylcholine bevatten niet-thrombogeen zijn (in tegenstelling tot fosforylserine-bevattende fosfolipiden). Omdat fosforylcholine in deze fosfolipiden de hydrofiele eindgroep vormt die in contact staat met bloed, en bovendien aangetoond werd dat ook fosforylcholine gekoppeld aan andere molekulen niet-trombogene eigenschappen bezit, is de belangstelling voor oppervlaktemodificatie-methoden die fosforylcholine-groepen kunnen koppelen aan polymeren sterk gegroeid. 
Het hier beschreven onderzoek gaat over een nieuwe methode om fosforylcholine-groepen covalent te koppelen aan een polyurethaan-oppervlak met als doel de bloedcompatibiliteit te verbeteren.

Hoofdstuk 2 beschrijft de synthese van enkele verbindingen die gebruikt kunnen worden om fosforylcholine-groepen te koppelen aan een polymeeroppervlak. De verbindingen bestaan uit een fotoreactieve groep (een azidofenylgroep) en een fosforylcholine-groep die van elkaar gescheiden zijn door een keten opgebouwd uit ethyleenglycol-eenheden. De fotoreactieve azidofenyl-groep is zeer stabiel maar kan door bestraling met UV-licht makkelijk omgezet worden in een zeer reactieve groep die kan reageren met zwak nucleofiele groepen op een polymeeroppervlak. De hier beschreven syntheses maken een snelle en veilige produktie mogelijk van fosforylcholine-bevattende arylazides.

In Hoofdstuk 3 wordt aangetoond dat arylazides covalent kunnen koppelen aan een polyurethaan (Pellethane ${ }^{(B)}$ 2363-55D) oppervlak. Voor dit doel werd een arylazide gesynthetiseerd met een fluorescerende dimethylaminonaftaleensulfonyl (dansyl) groep. Wanneer een oppervlak bedekt werd met deze verbinding, gevolgd door UV-bestraling, resulteerde dit in covalent gekoppelde molekulen, wat aangetoond kon worden door een snel hydrolyse-experiment. Verder werd gevonden dat een oppervlakte-dichtheid van ongeveer $25 \mathrm{nmol} / \mathrm{cm}^{2}$ bereikt kon worden met deze methode. Deze hoge oppervlakte-dichtheid zou mede veroorzaakt kunnen worden door de ruwheid van het polymeer-oppervlak (wat resulteert in een groter oppervlak) en een (geringe) zwelling van het polymeer waardoor modificatie optreedt tot op zekere diepte.

In Hoofdstuk 4 worden twee fosforylcholine-bevattende arylazides gebruikt voor de oppervlakte-modificatie van een polyurethaan (Pellethane) om de bloedcompatibiliteit van het polymeer te verbeteren. $\mathrm{Na}$ de fotochemische oppervlakte-reactie (vergelijkbaar met de procedure beschreven in Hoofdstuk 3) werden de polymeer-oppervlaktes geanalyseerd met contacthoek-metingen waaruit bleek dat de contacthoeken van alle gemodificeerde oppervlaktes afgenomen waren, zoals te verwachten is voor oppervlaktes met gekoppelde (hydrofiele) fosforylcholine-groepen. ESCA (Electron Spectroscopy for Chemical Analysis) metingen toonden aan dat de samenstelling van het oppervlak veranderd was en dat nu fosforylcholine-groepen aanwezig waren op het polyurethaan-oppervlak (de geanalyseerde diepte was ongeveer $50 \AA$ ). De bloedcompatibiliteit in vitro werd 
bepaald met thrombine-generatie tests en analyses van de adhesie van bloedplaatjes (voor beide typen experimenten werd plaatjes-rijk plasma gebruikt). De thrombinegeneratie tests toonden dat de bloedstollings-tijden van de polyurethaan-oppervlaktes die gemodificeerd waren met fosforylcholine-groepen duidelijk langer geworden waren, afhankelijk van de hoeveelheid fosforylcholine op het opperviak. Plaatjesadhesie werd bestudeerd met "scanning" elektronenmicroscopie waaruit bleek dat minder bloedplaatjes (die ook minder geactiveerd waren) aan de gemodificeerde oppervlaktes hechtten dan aan de niet-gemodificeerde oppervlaktes. De tests wijzen dus op een verbeterde bloedcompatibiliteit van de gemodificeerde polyurethaan-oppervlaktes.

In Hoofdstuk 5 worden enkelvoudige eiwit-adsorptie experimenten beschreven op gemodificeerde polyurethaan-oppervlaktes. Ellipsometrie werd gebruikt voor de eiwit-adsorptie metingen omdat het een van de weinige technieken is waarmee eiwitadsorptie continu en in situ gemeten kan worden. Op silicium-wafers werden dunne polyurethaan-films aangebracht waarna er fosforylcholine-groepen aan gekoppeld werden op dezelfde manier als beschreven in het vorige hoofdstuk. De adsorptie werd gemeten van enkele menselijke eiwitten: albumine (Alb), fibrinogeen ( $\mathrm{Fg}$ ) en hoog-moleculairgewicht kininogeen (HMWK) (het belang van deze eiwitten werd geschetst in Hoofdstuk 1). Uit de experimenten bleek dat de aanwezigheid van fosforylcholine-groepen op het oppervlak weinig invloed had op de eiwit-adsorptie, wat tegen de verwachting was. Wanneer de polymeer-oppervlaktes voorbehandeld werden met dioleoylfosfatidylcholine (DOPC) vesicles was de eiwit-adsorptie duidelijk lager op alle oppervlaktes. Op een DOPC-dubbellaag, gevormd op silicium, adsorbeerde geen van de eiwitten, zoals verwacht. Deze resultaten laten zien dat enkel de aanwezigheid van fosforylcholine-groepen op een polyurethaan oppervlak onvoldoende is om eiwit-adsorptie te onderdrukken (tenminste in enkelvoudige eiwit-adsorptie experimenten); voor een efficiënte onderdrukking van de eiwit-adsorptie moet waarschijnlijk een geordende en dicht gepakte laag van fosforylcholine-bevattende molekulen op het oppervlak aanwezig zijn.

In Hoofdstuk 6 worden de resultaten van deze studie bediscussieerd en worden enkele moeilijkheden beschreven die optreden bij het ontwikkelen van "bloedcompatibele" materialen. 


\section{List of publications}

- A.P. van der Heiden, R.T. Boaron, and L.H. Koole, "Synthesis of a homologous series of bifunctional photoreactive compounds carrying a phosphorylcholine moiety for the surface modification of polymeric biomaterials," submitted (1997).

- A.P. van der Heiden, G.M. Willems, T. Lindhout, A.P. Pijpers, and L.H. Koole, "Adsorption of proteins onto poly(ether urethane) with a phosphorylcholine moiety and influence of pre-adsorbed phospholipid," J. Biomed. Mater. Res., in press (1997).

- A.P. van der Heiden, D. Goebbels, A.P. Pijpers, and L.H. Koole, "A photochemical method for the surface modification of poly(ether urethanes) with phosphorylcholinecontaining compounds to improve hemocompatibility, ${ }^{\circ} J$. Biomed. Mater. Res., 37 , 282-290 (1997).

- A.P. van der Heiden and L.H. Koole, "Photochemical coupling of aryl azides to poly(ether urethane) surfaces: studies with a fluorescent model compound" Macromolecules, 29, 7012-15 (1996).

- A.P. van der Heiden and L.H. Koole, "Characterization of poly(ether urethane) surfaces photochemically modified with phosphory]choline-containing aryl azides," Fifth World Biomaterials Congress, Toronto, Canada (1996), Transactions, Vol. I, p. 652.

\section{List of earlier publications not related to this study}

- N.L.H.L. Broeders, A.P. van der Heiden, J.A. Kanters, A. Schouten, and L.H. Koole, "2'-O-Methyl-cis-adenosine 3',5'-cyclic methyl monophosphate, a new model system for cAMP. Aspects of structure and reactivity," Can. J. Chem., 71, 855-863 (1993).

- N.L.H.L. Broeders, A.P. van der Heiden, I. Peeters, H.M. Janssen, and L.H. Koole, "A ${ }^{\text {"1 }}$ PMR stereochemical and kinetic study of the alkaline hydrolysis of cis-nucleoside 3', $5^{\prime}$ cyclic aryl [ $\left.{ }^{18} \mathrm{O}\right]$ monophosphates and unlabeled analogs," J. Am. Chem. Soc., 114, $9624-33(1992)$.

- P.J.L.M. Quaedflieg, A.P. van der Heiden, L.H. Koole, A.J.J.M. Coenen, S. van der Wal, and E.M. Meijer, "Synthesis and conformational analysis of phosphate-methylated RNA dinucleotides," J. Org. Chem., 56, 5846-59 (1991). 


\section{Curriculum vitae}

Arthur van der Heiden werd op 11 oktober 1964 geboren in Geldrop. In 1983 behaalde hij het Gymnasium- $\beta$ diploma aan de Gemeentelijke Scholengemeenschap Genderdal in Eindhoven waarna in dat zelfde jaar begonnen werd met de studie Scheikundige Technologie aan de Technische Universiteit Eindhoven. Het doctoraal examen (afstudeerrichting Organische Chemie) werd in december 1989 met lof afgelegd. Aansluitend werd gestart met de tweejarige Korte Onderzoekersopleiding Scheikundige Technologie bij de vakgroep Organische Chemie van de Technische Universiteit Eindhoven en in maart 1992 werd het diploma behaald.

Na het vervullen van de militaire dienst kwam hij in april 1993 in dienst bij de Rijksuniversiteit Limburg (nu: Universiteit Maastricht) om het hier beschreven onderzoek te gaan verrichten bij de vakgroep Biochemie. Vanaf november 1994 werd het onderzoek voortgezet bij Biomat B.V., gevestigd binnen de Universiteit Maastricht. Het onderzoek stond onder leiding van Prof. Dr. H.C. Hemker en Dr. Ir. L.H. Koole. 


\section{Dankwoord}

Vele mensen hebben een bijdrage geleverd aan de realisatie van dit proefschrift. Graag wil ik hen hier danken voor de hulp en de stimulerende discussies.

Mijn co-promotor, Dr. Ir. L.H. Koole (Leo), wil ik bedanken voor het vertrouwen dat hij in mij heeft gesteld en voor de dagelijkse begeleiding van het onderzoek. Mijn promotor, Prof. Dr. H.C. Hemker, die het onderzoek op afstand begeleidde, wil ik bedanken voor het feit dat hij mij in de gelegenheid heeft gesteld dit onderzoek uit te voeren.

De voormalige HLO-studenten Rob Boaron, Daniëlle Goebbels en Cengiz Karabag dank ik voor hun belangrijke bijdragen aan het onderzoek en voor de plezierige samenwerking.

Mijn collega's op het laboratorium van het Maastricht Center for Biomaterials Research, te weten Ron Blezer, Yvette Aldenhoff, Marc-Anton Kruft en Abder Benzina dank ik voor de prettige samenwerking en de vele stimulerende discussies. Ron wil ik speciaal bedanken voor de nauwkeurig uitgevoerde bloedstollingstests.

Alle medewerkers en promovendi van de vakgroep Biochemie will ik danken voor de prettige werksfeer die er heerste. Dirk Rijkers wil ik in het bijzonder bedanken voor zijn belangstelling in het onderzoek en voor de wetenschappelijke discussies die wij gevoerd hebben, zowel op het lab als in de trein. Viviane Heijnen wil ik graag danken voor de SEM-metingen die zij heeft uitgevoerd. Theo Lindhout dank ik voor de prettige samenwerking en in het bijzonder voor zijn bijdrage aan hoofdstuk 5 van dit proefschrift. Trees Camphuisen wil ik bedanken voor alle administratieve hulp en de persoonlijke ondersteuning. De hulp van Rita Janssen bij de ellipsometrie-metingen heb ik zeer op prijs gesteld.

George Willems (Instituut voor Hart- en Vaatziekten) dank ik voor zijn kritische kijk op de uitgevoerde ellipsometrie-experimenten alsmede voor zijn nauwgezette controle van het artikel dat ten grondslag lag aan hoofdstuk 5 van dit proefschrift. Paul Pijpers (DSM Research) ben ik veel dank verschuldigd voor de ESCA-metingen die hij heeft uitgevoerd. 